March 2014

"Pesticides and health: A review of evidence on health effects, valuation of risks, and benefit-cost analysis"

Henrik Andersson, Damian Tago and Nicolas Treich 


\title{
Pesticides and health: A review of evidence on health effects, valuation of risks, and benefit-cost analysis
}

\author{
Henrik Andersson \\ Toulouse School of Economics (UT1C, CNRS, LERNA), France \\ Damian Tago* \\ Toulouse School of Economics (INRA, LERNA), France \\ Nicolas Treich \\ Toulouse School of Economics (INRA, LERNA, IDEI), France
}

Forthcoming in Preference Measurement in Health, an edited volume by Glenn Blomquist and Kristian Bolin in the series Advances in Health Economics and Health Services Research.

March 052014

\begin{abstract}
In this paper, we provide reviews of recent scientific findings on health effects and preference valuation of health risks related to pesticides, and the role of benefit-cost analysis in policies related to pesticides. Our reviews reveal that whereas the focus of the health literature has been on individuals with direct exposure to pesticides, e.g. farmers, the literature on preference elicitation has focused on those with indirect exposure, e.g. consumers. Our discussion of pesticides policies emphasizes the need to clarify the rationale for regulation and the role of risk perceptions in benefit-cost analysis, and stress the importance of inter-disciplinary research in this area.
\end{abstract}

Keywords: Benefit-cost analysis; Health; Pesticides; Willingness to Pay

* To whom correspondence should be addressed. Corresponding address: Toulouse School of Economics (LERNA), 21 all. de Brienne, 31015 Toulouse Cedex 6, France, Email: damian.tago@tse-fr.eu 


\section{Introduction}

The use of chemicals in modern agriculture has significantly increased productivity. But it has also significantly increased the concentration of pesticides in food and in our environment, with associated negative effects on human health. Annually there are dozens of million cases of pesticide poisonings worldwide (Richter, 2002). Moreover, it is now better understood that pesticides have significant chronic health effects, including cancer, neurological effects, diabetes, respiratory diseases, fetal diseases, and genetic disorders. These health effects are different depending on the degree, and the type of exposure. Typically, the effects are different for farmers who are directly exposed to pesticides, compared to those for farmers' relatives or people living in rural areas who are less directly exposed. There are also effects on consumers through pesticide residues in food.

Pesticides use and regulation have long been controversial. The publication in 1962 of the famous Silent Spring by the biologist Rachel Carson made popular the risks associated to DDT (dichlorodiphenyltrichloroethane) (Carson, 1962). This was followed by the cancelation of this pesticide for agricultural uses by US authorities. Other prominent examples of pesticide cancelation include EDB (ethylene dibromide) in 1983 and methyl bromide in 2005. It is well known now that a significant fraction of pesticides are carcinogenic; for instance, $18 \%$ of all insecticides and $90 \%$ of all fungicides were found to be carcinogenic (NAS, 1987). It is also well known that pesticide residues remain for long periods of time, and that they are especially toxic to the young. Also, pesticides kill domestic animals, fishes and bees. Moreover, their use results in the development and evolution of pesticide resistance in insects, weeds and plant pathogens. Nevertheless hundreds of pesticides are used worldwide, and some pesticides are used in some countries but not in others. For instance, the main pesticide which is used in corn production in the US is atrazine, but this pesticide has been banned in the EU because of its toxicity since 2004 (Official Journal of the European Union 2004/248/CE).

Public decisions concerning pesticides have long been suspected of regulatory capture. One of the reasons for transferring in 1970 pesticides regulatory responsibility from the US Department of Agriculture to the Environmental Protection Agency (EPA) was to lessen the influence of farmers and pesticide producers. But this transfer of responsibility naturally increased the influence of consumers and environmentalists. Indeed, Cropper et al. (1992) showed that both grower and environmental groups' participation played a major role in explaining the EPA decisions to cancel a pesticide in the 1970 s and 1980s. Risk assessment practices also play a role in pesticides regulation. The zero-risk or "de minimis risk" target has long been the advanced objective of regulators. But this objective is overly ambitious, and often not implemented as a result. There is a lot of evidence for instance that a significant portion of food samples still exceeds the maximum residue limits set by regulators both in the US and in Europe. Finally, risk perceptions may also influence pesticide regulation. Indeed, there is evidence that people underestimate the risks from natural carcinogens but that they nevertheless overestimate the risks from carcinogenic pesticides (Slovic, 2000).

These observations illustrate the challenge of regulating pesticides. At the root of this challenge there is the immense difficulty of producing more food with less pesticide, and the uncertainty about health effects of pesticides. Zilberman and Millock (1997) talk about a regulation nightmare. Given the growing health concerns of the population, some drastic actions to curb the use of pesticides have 
been decided in some countries. For instance, Denmark decided as early as in 1986 to reduce by two the pesticide treatment frequency in agriculture. More recently, France announced in 2008 a reduction by two of pesticide use by 2018 in its "Ecophyto 2018" plan (MAP, 2009). A major problem with such ambitious policy targets is that they need not reflect an appropriate balance of benefits and costs induced by pesticides use in our societies. Also, these policy targets are difficult, if not impossible, to implement in practice, in part because of the opposition of farmers. In this difficult political context, the US EPA has long noticed that producing sound comparisons of benefits and costs of proposed pesticides regulations might be helpful to policy makers in order to identify and design a coherent pesticide regulatory policy (EPA US, 1992). However, only few studies based on benefit-cost analysis (BCA) concerning pesticides have been produced so far (Pimentel, 2005).

The aim of this study is to contribute to the understanding of the health effects of pesticides exposure and of how pesticides have been and should be regulated. Our conceptual framework is BCA, namely the most common economic method to evaluate a public policy. In the context of pesticide regulation, this framework requires evidence on health effects on those exposed directly and indirectly, valuation of risks, consideration of market and nonmarket failures, policy alternatives, and estimates of costs. As a first step we provide literature reviews on recent scientific findings on health effects. As a second step, we provide evidence on preference valuation of health risks related to pesticides use. Finally, we provide an overview and discussion of different policies and of difficulties of evaluating them using BCA. One objective of these reviews is to relate the findings from the different disciplines (health, economics and public policy) to each other, and to identify gaps and needs for future research.

The paper is organized as follows. The following section contains the review of the finding on the health effects related to pesticides use. Section 3 thereafter, after a brief introduction on preference elicitation, summarizes the findings from the literature on individual preferences and pesticides. Both section 2 and 3 end with some concluding remarks on each topic. A review and discussion on how pesticides use has been regulated and evaluated are then provided in section 4 . We end the paper with some concluding remarks in section 5. Moreover, the Appendix contains a set of tables in which we briefly present the results of the scientific publications on health effects and valuation of risks selected in our sample.

\section{Health effects of pesticides}

The following section is dedicated to a survey of the existing literature on the health effects of pesticides. It focuses on agriculture exposure, so potentially harmful substances other than pesticides and different frameworks are out of the scope of this review. The analysis distinguishes between three types of studies depending on the people exposed: (i) people with direct exposure, (ii) members of a community with indirect exposure, and (iii) consumers.

Previous literature on potential health effects of pesticides first focused on the risks of acute intoxication among people with direct exposure. The availability of longitudinal data shifted the main concern to the risks of chronic intoxication and environmental contamination. More recently the concern moved to diseases such as cancer for which the risk is not associated with instant effects of pesticides but with chronic exposure. Nowadays, the concern about latent effects is not only on people 
with direct exposure but also on subjects with indirect exposure such as consumers or residents of rural communities. Different risks associated with pesticides are often classified based on whether they have short-term effects (such as diarrhea, abdominal pain, headaches, nausea, vomiting, etc.) or long-term effects (such as skin diseases, cancer, depression, neurological deficits, diabetes, genetic disorders, or even death).

Since the existing literature on this topic is quite extensive and some other reviews have already been conducted (see, e.g., Alavanja et al., 2004; Florax et al., 2005; Cocco, 2002; Garcia, 2003), we focused on studies from 2000 to the present. The literature review was conducted in March 2013, and we included only published studies with "pesticide" in the title and "health" in the title or abstract, or with "pesticide exposure" in the title. ${ }^{1}$ The search tool was EBSCOhost, which includes Business Source, EconLit, Medline, GreenFile, among others sources. We found 527 original texts, and after excluding news articles, books, and non-related or repeated results, we ended up with a sample of 191 studies.

Not including studies published before 2000 leads to an underrepresentation of certain health effects that are not in the agenda anymore such as skin reactions. On the other hand, chronic diseases have received more attention lately and this is reflected in the high number of publications analyzing these types of disease.

\subsection{Health effects of pesticides on people with direct exposure}

A wide range of subjects are included in this category. We considered studies whose subjects are not only people who spray pesticides, but also who mix and load the pesticides, sow pesticide-seeds, weed and harvest sprayed crops, and clean and dispose of containers. A total of 122 studies were found $(63.9 \%$ of the total), and Table 1 in the appendix presents their most relevant features. Most of the statistically significant results are pesticide-specific so it is not possible to generalize regarding health effects of pesticides.

\subsubsection{Cancer}

Cancer associated with pesticide exposure is one of the most studied topics related to pesticides' toxicity during the last decade. Of the studies found, 43 analyze the relation between direct exposure to pesticides and the risk of cancer. Most of the studies use the Agricultural Health Study (AHS) data. No unanimous agreement has been reached: 12 of the studies report no significant evidence of increased risk of cancer among farmers exposed to pesticides compared with the risk of the general population (see, e.g., De Roos et al., 2005; Greenburg et al., 2008; Lynch et al., 2006), while the rest of the studies (31) conclude that exposure to certain pesticides significantly increases the risk of cancer (see, e.g., Lynch et al., 2009; Alavanja et al., 2003; Beane et al., 2005). The heterogeneity of the results is related to the type of cancer being analyzed as well as the nature of the pesticides. ${ }^{2}$

\footnotetext{
${ }^{1}$ More general searches were tested, but mostly the number of non-related papers increased substantially.

${ }^{2}$ Weichenthal et al. (2010) reviews in a simplified way the epidemiologic evidence related to occupational pesticide exposures and cancer incidence in the AHS cohort. Some of these studies were not included in our review since they were published in journals not considered by our search tool.
} 


\subsubsection{Depression and neurological deficits}

The evidence found in 3 studies suggests that high-intensity and cumulative pesticide exposure contributes to depression among pesticide applicators (see, e.g., Beseler et al., 2008). Different studies have been carried out analyzing the effects of pesticide exposure on neurological function. Evidence relating long durations of farm work with decreasing levels of performance has been found, and one relevant factor might be chronic exposure to pesticides (Kamel et al., 2003). Results are mixed depending on the pesticide being analyzed: some of them suggest that neurological symptoms are associated with cumulative exposure, but this is true only for some fumigants and insecticides (Kamel et al., 2005), and some pesticides, such as triallates, have no effect at all (see, e.g., Sathiakumar et al., 2004).

\subsubsection{Diabetes}

More recent studies look for a link between diabetes risk and pesticide exposure. Exposure to organochlorine compounds is associated with increased prevalence of diabetes (Cox et al., 2007) as well as handling organophosphate insecticides (Montgomery et al., 2008). All the studies in this section find a significant association between pesticide exposure and diabetes, but the number of studies ( 3 ) is not large enough to formulate a general conclusion.

\section{$\underline{2.1 .4}$ Respiratory diseases}

There were 13 studies about respiratory diseases and its relation to pesticide exposure. Most of them suggest an increased risk of respiratory diseases such as rhinitis (see, Slager et al., 2009), asthma (Hoppin et al., 2009), bronchitis (Hoppin et al., 2007c), farmer's lung ${ }^{3}$ (Hoppin et al., 2007a), and wheeze (Hoppin et al., 2002). However, Fieten et al. (2009) highlights the fact that it is not possible to establish a causal relationship, and 2 studies do not support a significant association (see, e.g., Boers et al., 2008).

\subsubsection{Women specific disorders}

There were 5 studies in which the authors analyze the relationship between pesticide exposure and women specific disorders. Regarding the age at menopause the results are mixed: Farr et al. (2006) finds that exposure is associated with a higher age at women's menopause, while Akkina et al. (2004) reports the opposite result. The rest of the studies find that pesticide exposure is a cause of hormonal disorders (see e.g., Farr et al., 2004), but it has no effect on delayed conception in pregnant women (Lauria et al., 2006).

\subsubsection{General health, multiple diseases, and others}

In this section we included studies that analyze the impact of pesticide exposure on general health or on several diseases (33 studies in total). There are studies of diseases such as hepatitis, dyspnea (Azmi et al., 2006), hearing loss (Crawford et al., 2008), myocardial infarction (Dayton et al., 2010), thyroid disease (Goldner et al., 2010), sperm quality (see, e.g., Perry et al. 2011), and of general measures such

\footnotetext{
${ }^{3}$ Farmer's lung is a hypersensitivity pneumonitis induced by the inhalation of biologic dusts coming from hay dust or mold spores or other agricultural products.
} 
as human health hazard levels (Murphy et al., 1999) and even suicides (Beard et al., 2011). Some studies highlight that precautionary measures have a significant impact on the relationship between pesticides and disease (Sekiyama et al., 2007), while others find significant interaction effects on health of pesticide exposure and genetic polymorphisms (see, e.g., Lacasaña et al. 2010b). New studies include clever techniques to analyze the effects of pesticides, such as invitro tests (Orton et al., 2011), that enhance the identification of pesticides' effects. ${ }^{4}$

\subsection{Health effects of pesticides on members of a community with indirect exposure}

There were 64 studies (33.5\% of the total) analyzing the impact of pesticides on the health of people with indirect exposure. The subjects of these studies include farmers' family members or people living in rural areas where there is an intensive use of pesticides. The main features of these studies are summarized in Table 2 in the appendix.

\subsubsection{Cancer}

We found 16 studies on cancer risk and indirect pesticides exposure among which no consensus is reached. For example, while 5 studies find evidence associating pesticide exposure (environmental, or prenatal) with increased risk of childhood leukemia (see, e.g., Ferreira et al. (2013)), Pearce et al. (2006) reports no significant association. In total, there are 3 studies whose evidence suggests no significant association between increased risk of cancer and indirect pesticide exposure (see, e.g., Carreon et al. (2005)), while the rest conclude the opposite, at least for some specific pesticides.

\subsubsection{Depression and neurological deficits}

There were 11 studies examining whether neurological effects are related to indirect pesticide exposure. The studies look at the risk of depression for spouses of pesticide applicators (Beseler et al., 2006), decreases in neurobehavioral development (see, e.g., Bouchard et al., 2011; Eskenazi et al., 2010; Harari et al., 2010), Parkinson's disease (Yesavage, et al., 2004), and the effect on children's IQ scores (Rauh et al ., 2011). Even when exposure is indirect the risks of neurological damage may increase, especially for children whose exposure takes place during early stages of fetal development (Eskenazi et al., (2007)).

\subsubsection{Diabetes}

Only 2 studies were found looking at increased risk of diabetes, and both conclude that pesticide exposure can be associated with an increased risk of diabetes (Everett et al., (2010), Son et al. (2010)). The number of related studies is too small to end up with a general conclusion, but this should motivate more research regarding this type of risk.

\section{$\underline{2.2 .4}$ Respiratory diseases}

It was surprising to find only 1 study looking at the risk of respiratory diseases (Balluz et al. (2000)). This study suggests that the health complaints reported by employees at a health center whose first floor

\footnotetext{
${ }^{4}$ These laboratory methods allow the researcher to recreate the exposure of specific cells to pesticides, isolating the pure-pesticide effect.
} 
was used as a mixing area for pesticides 20 years before, were precipitated by environmental and psychological factors, more than actual exposure to pesticides. More evidence is needed to come up with a general conclusion.

\subsubsection{General health, multiple diseases, and others}

There were 32 studies gathered in this section. While some studies find no long-term health risks from potential inhalation of pesticides (Murphy and Haith, 2007), or no association between birth weight and pesticide related activities during early pregnancy (Sathyanarayana et al., 2010), others find significant effects over certain variables, such as body mass index (Burns et al., 2012), endocrine performance (Cecchi et al., 2012), and fetal growth (Wickerham et al., 2012). Recent studies look at the effect of indirect exposure on health outcomes taking into consideration genetic heterogeneity among subjects (see, e.g., Andersen et al., 2012).

\subsection{Health effects of pesticides on consumers}

Although we expected to have more studies in this section, only 5 studies were found ( $2.6 \%$ of the total) and most of them related to cancer risk. Main results are presented in Table 3 in the appendix.

\subsubsection{Cancer}

The studies on cancer analyze the risks associated with the consumption of specific products which have some pesticide residues. These consumption products include: fish (Li et al., 2008), water (Buczynska and Szadkowska, 2005), seafood (Moon et al., 2009), and milk or other dairy products (Pandit and Sahu, 2002). In general these studies find a small but statistically significant association between cancer risks and some specific pesticide residues, such as DDT and DDD (dichlorodiphenyldichloroethane), but not for other organochlorines. Specifically PCBs (polychlorinated biphenyls) present a higher risk for consumers (see e.g., Li et al., 2008).

\subsubsection{General health, multiple diseases, and others}

Only 1 study was found analyzing pesticide residue concentration in vegetables and finds that the risk posed to consumers varies with the season (Bhanti et al., 2007). The winter season has the highest pesticide concentrations in vegetables that might accumulate in the person's body and lead to fatal consequences in the long run. However, only methyl parathion residues have a significant hazard index, so this result is also pesticide-dependent.

\subsection{Concluding remarks on health effects and pesticides}

Most of the studies found in our literature review are related to the health effects on people with direct exposure (63.9\%). Research on people with indirect exposure is harder to find, while research on the risk of pesticide residues for consumers has not really been part of the agenda. Therefore, more research is needed to analyze the potential health effects of pesticides on these subjects.

Regarding data availability, the AHS is the main database used in a large number of the studies (in more than $40 \%$ for direct exposure and almost $20 \%$ for indirect exposure). More studies collecting data should be conducted to validate the results since the AHS might be influenced by geographical 
conditions (only two states are represented: lowa and North Carolina). Moreover, in the AHS the enrollment process was voluntary and the first approach was made during the training to obtain a license to apply pesticides; as a result, selection bias is one concern. Nevertheless, this study compares favorably with enrollment rates of previous prospective studies, so more initiatives like this should be considered to improve research in this field.

Previous literature surveys (published before 2000) have analyzed only the hazard effects of direct exposure. Do Pico (1992) provides similar conclusions to those we find regarding respiratory diseases: hazardous exposures (including pesticides) can develop into respiratory disorders such as asthma, bronchitis, solo filler's disease, and neuromuscular respiratory failure. Eyer (1995) finds that exposure to high doses of organophosphates with clinically significant intoxications can affect behavior, as well as mental and visual functions, whereas asymptomatic exposure is not connected to neuropsychopathological disorders. These results are similar to what can be concluded from our review: results are pesticide-specific and sometimes depend on the length of the exposure period.

Moreover, Blair et al. (1995) suggests an association between pesticide exposure and cancer. Our review provides stronger conclusions due to new findings on some pesticides increasing the risk of cancer (such as metolachlor and diazinon on lung cancer). The review by Dich et al. (1997) on cancer risk links phenoxy herbicides with soft tissue sarcoma (STS), organochlorine insecticides with STS, nonHodgkin's lymphoma (NHL), leukemia and lung and breast cancer; organophosphorous are linked with $\mathrm{NHL}$ and leukemia; and triazine herbicides with ovarian cancer. This review highlights that "few, if any, of these associations can be considered established and causal" which is a concern that can be extended to many of the studies included in our review.

Arbuckle et al. (1998) suggests an increased risk of fetal deaths associated with pesticides and maternal employment in the agricultural industry. Similarly to one of the studies on pesticide exposure during early pregnancy found in our review (Sathyanarayana et al., 2010), the authors face problems because of the lack of data and methodological issues.

We consider the results of this review consistent with previous ones. The links between health risks and pesticide exposure are pesticide-dependent, the existing findings often disagree, there is a lack of data in order to obtain more reliable results, and there still exist some methodological issues that could be improved to deal with the low number of cases, and potential regional effects or biases.

\section{Preference elicitation}

In this section we first briefly introduce the monetizing of preferences for health risks. Next we present recent empirical findings on the evaluation of reduced pesticides use. The section ends with some conclusions regarding the empirical research that has been conducted and the way to proceed.

\subsection{Health risk valuation}

Valuation of pesticide risks is based on the notion that individuals are the best judges of their own welfare. The monetary value of a change in the risk level should therefore reflect the preferences and perceptions of those individuals who are exposed to the risk. This includes both groups who have direct contact with the pesticides, such as producers and farmers, and those who are indirectly 
affected, such as consumers of products that contain pesticide residue, people who are exposed when visiting the countryside for recreational purposes, etc.

Since no directly observable prices exist for pesticide health risk reductions, analysts have to rely on non-market evaluation techniques to monetize individuals' preferences. ${ }^{5}$ The monetary values obtained using these techniques reflect the individuals' willingness to pay (WTP) and willingness to accept (WTA) for a reduction and increase in the risk level. Thus, since the individual WTP and WTA reflect how much individuals are prepared to give up or how much they require in compensation for a risk change, they reflect individual preferences. Non-market evaluation techniques can, broadly speaking, be classified as revealed- (RP) or stated-preference (SP) techniques. This classification is based on the approach used to obtain information about individuals' preferences. In the former, the RP approach, analysts use the information from individuals' actual decision on existing markets to derive the monetary value of a change in risk. In contrast, in the SP approach, respondents are asked to make decisions in constructed markets where the scenarios are hypothetical. Both approaches have their strengths and weaknesses.

When using market data to monetize preferences for non-market goods (or bads) the analysts observe behavior on markets related to the good of interest. Individuals' decisions then reveal their preferences for the good of interest. Economists often prefer the RP to the SP approach since it is based on actual decisions. Not only because an observed choice reveals that the individual prefers his choice to other available alternatives, but also because many decisions are made repeatedly. Thus, individuals learn by experience and have incentives to seek information and to be well-informed about the decision alternatives available. An example where the RP approach has been used to monetize health preferences is car owners' decisions on optimal car safety level (Atkinson and Halvorsen, 1990; Andersson, 2005). The premium paid for a safer car reflects the WTP to reduce risk exposure (everything else equal). Moreover, the RP approach has been used extensively to analyze and derive preferences for safety in the labor market where workers demand for compensation to accept riskier jobs (Viscusi and Aldy, 2003). However, even if the RP approach has its strengths it also has its weaknesses. It relies on the assumption that individuals make well-informed decision and that the analyst has knowledge about the information and decision alternatives that individuals face when making their decisions. Market data availability is crucial; obtaining market data for some goods may not be possible, while markets may not exist for others.

The weaknesses of the RP approach are the strengths of the SP approach. Since the SP approach is based on a hypothetical market setting, the analyst has the freedom to tailor the scenario to elicit preferences for the specific question he is interested in. This means that: (i) the analyst knows about the information and the decision alternatives the respondent has access to, (ii) any (at least in theory) market can be constructed, and therefore (iii) data will be available. This does not mean that the SP approach does not have its weaknesses, though. Its main weakness is the hypothetical nature of the market, which is also the reason why many economists prefer the RP approach, and the fact that

\footnotetext{
${ }^{5}$ There is now a huge literature on the evaluation of non-market goods. We aim at keeping the references in this section to a minimum, and for those interested in an introduction to the topic we suggest Bateman et al. (2002) and Haab and McDonnel (2003), but there are many other good textbooks on the subject, including books on BCA such as Boardman et al. (2011).
} 
respondents are often asked to state their preferences for goods that are unfamiliar to them as a "market good", i.e. they are not used to trade them in a market. The combination of the hypothetic market and an unfamiliar good may lead to respondents not stating their "true" preferences. Due to the hypothetical nature respondents may not have incentives to make the effort to understand the scenario and its consequences, and may instead have incentives to answer strategically, i.e. in a way that is in their own interest. For instance, they may state a higher WTP than their true one since they know that they will not actually have to pay the amount. However, despite these weaknesses SP methods have been used in many studies to evaluate health risks in many areas due to the strengths mentioned above (Hammitt and Graham, 1999; Florax et al., 2005; Andersson and Treich, 2011; Kling, et al., 2012).

Health risks affect individual utility and therefore the WTP estimated, either with RP or SP techniques, reflects a use value to the individuals. In the literature on non-market evaluation the distinction between use and non-use value is an important one. The latter refers to goods for which individuals have a positive WTP, despite the fact that they have no personal direct gain from the goods. For instance, individuals may be prepare to pay some amount of money to save endangered species even if they have no commercial interest (e.g. organizing commercial safari trips), or have any chance of seeing the animal or benefit from it in any other way. The distinction is relevant for pesticide risks, since they affect both individual health and the environment. Regarding the latter, the effects from pesticide use can have both use value, such as commercial values for recreation, fishing, etc., but also non-use values, for instance a belief about an intrinsic value for species and habitats, or a WTP to preserve the environment for future generations. An important difference between the two is that non-use values are typically estimated with SP methods, since the RP approach relies on the information on individuals' behavior in markets.

In addition to RP and SP studies, WTP can be elicited in experiments. These experiments often take place in a laboratory with constructed markets where subjects must make a commitment, which usually involves a money transfer. Experiments are usually not used to derive monetary values for policy purpose, e.g. values to be used in BCA, but are instead used to examine hypothesis about behavior or methodological issues.

\subsection{Evidence from the literature on the evaluation of pesticide risks}

The risk of pesticides to human health has been of public concern since the 1970s. The benefits of pesticide use then started being weighed against their costs, which led to research being conducted monetizing the benefits and the costs. Most of the early work was conducted in the US and after only a few studies were carried out in the 1980s, there was a rapid growth in the number of studies in the 1990s. This early work was reviewed and analyzed in Florax et al. (2005) and Travisi et al. (2006). We therefore restrict our review to studies published from 2000 to the spring of 2013 (when the review was conducted). We used the same search tool as for the review of health effects from pesticides, i.e. EBSCOhost, and we restricted the search to published peer-reviewed articles in scientific journals. We used the search criteria "pesticide" and "willingness" in either the title or the abstract. We do not restrict our review to only studies eliciting WTP related to human health risk. Instead we include all 
relevant studies eliciting individual WTP to reduce or eliminate pesticides use. We found 32 studies that met our requirements and were studies eliciting monetary values to reduce pesticides usage.

The studies are presented in alphabetical order in Table 4 in the appendix. The studies are classified: (i) according to origin, i.e. the country in which the study was conducted, (ii) what type of actor, which has been defined as either farmer or consumer, (iii) which study type, where the study is defined as either RP or SP, but also the actual technique is specified, and (iv) what type of good WTP is elicited for. Regarding type of actor, some studies did not specify that the sample represented consumers, but instead the general public was the target. We have coded this group as consumers. Regarding the type of good we have grouped the studies into health $(H)$, environment $(E)$, organic $(O)$, and miscellaneous (M). Miscellaneous could, e.g., refer to "non-GM" (genetically modified) goods. The table reveals that WTP reflects more than one type of good in several studies. The final column of the table describes how WTP was defined in the study, e.g. as a price premium for a pesticide free product compared with a conventional product.

The review shows that it is still in the US where most studies are being conducted. There has been a growing interest in Europe, though; we found 11 studies conducted primarily in the UK and Italy compared with one study conducted in the UK before 2000 (Florax et al., 2005; Travisi et al., 2006). The review also reveals that most studies are conducted with the aim of eliciting consumers' preferences. Only 6 of the 32 studies focused on farmers. Moreover, there seems to be more interest in farmers' preferences in the developing world; 5 out of the 7 studies conducted in Turkey, Ghana, Nepal, Nicaragua, Pakistan, Thailand, and the Philippines are on farmers' preferences compared to only one study in the US, Canada, and western Europe. Further, a huge majority of the studies were conducted using SP compared to RP techniques or experiments, 25 out of 32, with two studies using both SP and $\mathrm{RP}$ techniques or experiments. Finally, three types of "goods" dominate, a reduced pesticide use that reduces health risk, health risk and environmental effects, and organic produce.

The almost non-existing interest in farmers' preferences in the developed countries could reflect the view that the farmers in these countries are well protected by available safety equipment and also by legislation. It could also be argued that they are well informed, and therefore make wellinformed decision on their optimal risk exposure without any need for additional government intervention. Indeed, the only study conducted in these countries used RP data to examine farmers' preferences for reduced pesticide use with a positive impact on both health and the environment (Sydorovych and Michele, 2008). The studies on farmers in the developing world focused on the health effects (Atreya et al., 2012; Garming and Waibel, 2009; Khan, 2009; Palis et al., 2006), with one exception that elicited WTP for a more efficient pesticide (Al-Hassan et al., 2010). Focusing on the studies eliciting WTP for health, Garming and Waibel (2009) and Khan (2009) employed the contingent valuation method (CVM) which is an SP method that directly ask respondents about their WTP, either as an open-ended question where respondents state their maximum WTP, or in a referendum format where respondents are asked to agree or not to pay a specified bid. ${ }^{6}$ Both studies asked respondents whether they were prepared to pay a premium for a pesticide that was safer to use, either compared

\footnotetext{
${ }^{6}$ This description is highly simplified. For a more comprehensive description of the design of CVM surveys see, e.g., Bateman et al. (2002).
} 
to a "standard pesticide" or the one that they currently used. Palis et al. (2006) instead created an experiment where farmers and laborers in the agricultural sector were offered protective equipment that they could buy, whereas Atreya et al. (2012) employed both the CVM and information on the farmers' reported expenditures on different safety measures.

The studies focusing on consumers' preferences in most cases asked respondents if they were prepared to pay a price premium for either a specified product, such as tomatoes or a loaf of bread, or a "basket of products". All but four studies (in one case a lab experiment (Marette et al., 2012)) were based on SP data and often framed as either organic or "non-GM", i.e. it was not specified that the good would reduce health risks and/or have a positive impact on the environment (see, e.g., Balcombe et al., 2007; Canavari and Nayga, 2009; Loureiro et al., 2002). Hence, in those studies respondents' WTP reflect their preferences for organic and non-GM food. This is also the case for the one RP study that was conducted which elicited parents' WTP for organic food for their babies (Maguire et al., 2004). Using RP data it can be difficult to disentangle the different attributes of the goods that influence buyers' WTP, i.e. it is hard to know if consumers of organic food buy it for the health benefit, because it is more environment friendly, the taste, or something else. For instance in the experiment in Nielsen (2013) subjects were asked to choose between fries from conventional or GM potatoes, where the latter were described as "environmentally friendlier". In a follow-up survey many subjects reported, though, that their decision about the GM fries was influenced by health concerns. The SP approach offers here an advantage compared to the RP approach, since it is possible to specify what the positive effects are for reduced pesticide use and then to derive specific monetary values for each effect. Many of the CVM studies also framed the scenario such that respondents were informed that they would either benefit from better health or environment from reduced pesticide use (e.g., Akgüngör et al., 2001; Hammitt and Haninger, 2010). Other SP studies employed the choice experiment (CE) technique, which is based on a multiattribute scenario which enables the analyst to derive monetary values for the chosen attribute. Hence, by having respondents choosing between products with different levels of the attribute, their WTP for each attribute can be estimated. For instance, Balcombe et al. (2009) and Travisi and Nijkamp (2008) used the CE technique to derive monetary values for different types of pesticides and for both health and environmental attributes, respectively.

The description of the WTP in the final column of Table 4 shows that, in general, the WTP is either defined as a price premium of a specified product or basket of products, or that no WTP was specified (NA). The objective of many studies (e.g., Canavari and Nayga, 2009; Govindasamy et al., 2001) was not to estimate monetary values for policy use (BCA, taxation, etc.), but to examine whether consumers' preferences are heterogeneous and whether respondents are willing to pay more for produce: (1) that contain, or are produced with fewer, pesticides, and (2) are organic, non-GM, etc. Thus, "not available" (NA) defines studies in which the respondents were not provided any reference price such that a monetary value could be derived or when authors did not reported any monetary values as in the experiments by Palis et al. (2006) and Nielsen (2013).

\subsection{Concluding remarks on preference elicitation to reduce pesticide risks}

The review reveals heterogeneity in goods used, and therefore in monetary values estimated. The design of the surveys suggests that the main objective of these studies is not to derive monetary values 
that reflect individual preferences that could be used for policy purposes. Instead, the two main objectives seem to be to examine whether: (i) individuals have a positive WTP for produce with less pesticide, with positive benefits for the health and the environment, or for organic or non-GM produce, and (ii) preferences are heterogeneous in the population. The evidence is strong that WTP is positive, both among consumers and farmers. There is also some evidence that preferences vary with individual characteristics, such as gender, age, income, and experience with pesticides.

Whereas the analysis of the effects from pesticides reported in section 2 mainly focused on specific pesticides and health effects, the WTP literature on pesticides have mainly elicited individuals' preferences based on non-specified pesticide use with general health effects. Moreover, whereas the health studies focused on people with direct exposure, consumers' preferences were of main interest in the WTP studies. These differences between the health and WTP literature are expected. The former is interested in the direct effect from specific pesticides on well-defined, or in some studies general, health effects to examine which pesticides are dangerous to human health. This is also of interest to analysts estimating WTP, but it can be hard to identity the effect from single pesticides using market data (RP) and to communicate the health effects from single pesticides in SP studies. Instead most of the WTP studies describe a general health impairment from pesticide exposure, usually related to consuming either "pesticide safe/free" food (e.g., Akgüngör et al., 2001; Cranfield and Magnusson, 2003; Posri et al., 2007), or organic food (e.g., Canavari et al., 2005; Haghiri and McNamara, 2007).

The research on WTP to reduce health risks from pesticide use contrasts health risk evaluation in many other fields such as workplace safety (Viscusi and Aldy, 2003) and traffic safety (Andersson and Treich, 2011). In those studies the risk reduction is defined as a change in the probability of an adverse health effect, injury or fatality, which enables the analyst to normalize the derived WTP to a "standardized value", such as the value of a statistical life (VSL) for a reduction in fatality risk (Jones-Lee, 1976, Cropper et al., 2011). The only study following this approach was Hammitt and Haninger (2010) which estimated the VSL. Two other studies, Mourato et al. (2000) and Travisi and Nijkamp (2008), followed a similar approach and valued cases of illness due to pesticide exposure. They both estimated WTP for a non-fatal outcome with the illness specified so that all respondents had the same information regarding the health impairment. The advantage of using a standardized value is that it can be compared between studies, and that it is better suited for benefits transfers.

The reason most WTP studies have focused on consumers' preferences instead of those individuals with direct exposure is probably because the latter group is relatively small, especially in developed countries. Even if the individual cost from impaired health is substantial for a farmer compared with a consumer, the total social cost from the second group is likely to be substantially higher due the large number of individuals in the second group. From a social perspective it therefore seems reasonable to continue focusing on consumer preferences, even if the preferences of those with direct exposure shall not be neglected.

It is established in the health literature that pesticide exposure has often a negative impact on individual health, even if it varies with type of pesticide. It is also established from the WTP literature that individuals are prepared to pay a premium for pesticide free or "safe" produce. We believe, though, that it is necessary for the WTP research to be more precise about what the WTP reflects. 
When eliciting WTP for organic produce, for instance, the premium paid probably measure taste, and environmental and health concerns, but maybe also other characteristics such as supporting locally grown produce, etc. Moreover, even if we would know which attributes consumers pay for, we would not know their shares of the WTP. Thus, to obtain monetary values that can be used for benefits transfer, i.e. that are not too context specific, it is necessary that the health outcomes are precise and/or that WTP is elicited for given amounts of specific pesticides. Hammitt and Haninger (2010) excluded the use of organic produce when eliciting their WTP for a fatality risk to minimize the risk of respondents also weighing in environmental and other characteristics when answering the WTP question and thereby obtaining a confounded measure of WTP. Chalak et al. (2008) in their choice sets specified the change of use from different types of pesticides. This approach does not directly elicit respondents' WTP for specific health outcomes, but it allows the analysts to elicit preferences for specific types of pesticides and based on the evidence from the health literature the health effects due to changes in pesticide levels can be estimated by the analyst.

\section{Pesticides and policy}

\subsection{Benefit-cost analysis}

In most countries, pesticides sales and use must be approved by public authorities. In the US, the EPA is responsible for pesticide regulation under the Federal Insecticide, Fungicide, and Rodenticide Act (FIFRA) and the Food Quality Protection Act (FQPA) (see for instance Berwald et al. (2006) for a presentation of pesticide regulation and policy use of economic analysis in the US). In principle, the EPA regulates pesticides to ensure that these products do not pose adverse effects to humans or the environment, whereas FIFRA explicitly advocates a balancing criterion in the sense that pesticides use is permitted absent "unreasonable risks" to human life or the environment. This balancing criterion seems consistent with the use of BCA, which has been a legal obligation in the US since the early 1980s (Sunstein, 2002). ${ }^{7}$ But in practice EPA through FIFRA essentially seeks to reduce exposures to carcinogenic pesticides below an individual risk level of 1 in 1 million, with some tolerance for higher levels. Similarly EPA through FQPA admits tolerances for carcinogenic pesticide residues in food such that there is a "reasonable certainty that no harm will result from aggregate exposure to the pesticide". A similar approach is adopted in Europe where for instance pesticide residues on crops are monitored through a maximum residue level (MRL) (EFSA, 2013).

Therefore, as in many other areas of risk regulation, the "de minimis risk" approach is the predominant approach influencing pesticide regulation (Adler, 2005). Essentially, this approach means that policy makers are instructed by their authorities to ensure that the probability of some bad outcome is below a low probability threshold. An advantage of this approach is that it seems simple, "fair", and can be easily translated into law. This approach might also be judged convenient politically since it often suggests that safety is ensured below the critical threshold. Obviously, this is often an

\footnotetext{
${ }^{7}$ We must add that BCA has been required except when prohibited by law or interpreted that way by administrators. For instance, the well-known and extremely controversial Delaney Clause precluded the use of BCA considerations for any cancer-causing additive. Pesticides were removed from the Delaney clause in 1996.
} 
illusion of safety since many pollutants do not have thresholds below which they have no effects. Moreover, as we discussed above, the threshold might be too ambitious and impossible to reach, and thus not implemented in practice. However, perhaps the most fundamental reason for why the de minimis risk approach is problematic is an economic one. Indeed, under a de minimis risk approach, the cost of regulation is not counted, and thus this cost cannot be compared to the benefit of the risk reduction target. To illustrate the inefficiency, consider that for some pesticide it is extremely costly to reach the threshold, while for another pesticide it is not so costly, and it might even not be very costly to reduce the risk further. Moreover, imagine that the first pesticide only concerns a few people while the second concerns millions of people. So targeting a uniform probability threshold of risk exposure across pesticides and populations seems particularly inefficient in general.

These observations relate to long-standing concerns about risk assessment practices. A major concern applies to the related "individual risk" approach. This approach typically computes a threshold probability using a hypothetical individual model with unrealistic assumptions like high exposure, high ingestion rates, low body rate etc. Besides, ad hoc "safety factors" are often employed when some causal relationships are uncertain. Moreover, when some parameter is unknown, extreme percentiles of the probability distribution are often used. This implies that risk assessment practices may induce a conservatism bias. For instance, Belzer (1991) estimated that the de minimis risk estimated by the EPA for dioxin was 5,000 times greater than its expected value, and that of perchloroethylene was 35,000 times greater than its expected value. As a consequence it has been suggested that the de minimis approach may lead us to go much too far in terms of regulation. To illustrate, we mention here the spectacular figure of the BCA about the regulation of atrazine/alachlor drinking water standards which revealed a cost per life saved of US\$92,000 million. This is the most inefficient policy of all policies reported in Sunstein (2002) that might well be explained by a conservatism bias.

Cropper et al. (1992) develop an econometric study of the overall EPA pesticide cancelation policy between 1975 and 1989. Their results offer some good news for economists. Indeed, they show that the probability of cancelation of pesticides is increasing in environmental and health risk and decreasing in economic benefits of pesticide use. However, the study also shows that EPA uses an implicit VSL for pesticide applicators of US\$35 million while the implicit VSL for consumers is only US\$60,000. Interestingly, EPA recommends elsewhere in BCA guidelines to policy makers to use VSL in the range of US\$1 to US\$10 million. Therefore, the estimates of Cropper et al. (1992) show inconsistency across EPA practices. Note that this inconsistency can be explained by EPA targeting higher risks. Indeed, the risk of exposure to a pesticide applicator has been estimated to be about 15 times higher than that of a consumer. This observation is consistent with the de minimis risk approach discussed above, in which regulators target a maximal risk but do not compare the relative benefits and costs of changing the risks. Along similar lines, Van Houtven and Cropper (1996) find evidence that EPA is biased toward minimizing risk for target vulnerable populations, like farm workers.

We now report the results from Pimentel (2005) who provides the only full-fledged BCA of pesticide use that we are aware of. He estimates that the direct benefit and cost for US farmers of using pesticides are respectively US\$40 and US\$10 billion. Moreover there is an indirect cost for farmers in terms of loss of natural enemies (US\$0.5 billion), pesticide resistance (US\$1.5 billion) and crop losses (US\$1.4 billion). Pimentel (2005) also estimates that indirect environmental losses, mostly 
through bird losses, amount to slightly more than US\$2 billion. Moreover, he estimates the cost for monitoring and cleaning pesticide-polluted groundwater to about another US\$2 billion. Finally, he estimates the health costs, including costs of hospitalization due to poisoning, of outpatient-treating poisonings, pesticide cancers and fatalities (with a VSL of US\$3.7 million), to about US\$1.3 billion. These results suggest that the use of pesticides is largely beneficial to the society. Nevertheless Pimentel (2005) adds that some costs are ignored or not accurately measured in his BCA, and thus a "complete and long-term [BCA] of pesticide use would reduce the perceived profitability of pesticides". We must also notice that an important limitation in this study is that it assesses the cost and benefit of full elimination of pesticides. In fact, realistic policy options concern the reduction of pesticide use, not its full elimination. Yet, evaluating these policy options require more precise information, typically in the form of dose-response relationships.

Following the brief presentation of the BCA of Pimentel (2005), we highlight some conceptual difficulties to apply BCA to pesticides use and regulation. We only discuss here the case for regulating pesticides for protecting the health risks of farmers, and of consumers, which is the main focus of our review. Indeed, we note that farmers have the choice on whether to purchase and use special equipment to protect them from pesticides. They can also choose crops that are more or less intensive in pesticides use. They can choose not to use pesticides at all, that is, to produce organic food. At the limit, they can even choose another occupation. Clearly, for farmers, there is a cost of using pesticides in terms of the input cost in production and the possible acute and chronic health risks. But there is also benefit of using pesticide which improves productivity and provides a self-insurance against pest uncertainty. But these are essentially private costs and private benefits. Indeed the analysis of Pimentel (2005) indicates that the use of pesticides is strongly profitable to farmers (i.e., a cursory analysis using his data indicates that a US\$1 dollar investment in pesticide control returns about US\$3 including monetized health costs). It is no surprise that the main opponent to the major revision of workers' protection standard for agricultural pesticides issued by EPA was the Department of Agriculture (True, 1997). It is not clear that there are solid arguments for government intervention in pesticides control on the ground of protecting farmers' health alone. This observation is in turn consistent with the high implicit VSL of US\$35 million for pesticide applicators estimated by Cropper et al. (1992), which suggests that regulation went too far.

What about the case for regulating pesticides for protecting the health of consumers? It may well be that the society gain in terms of cheaper food is much higher than the monetized health cost of pesticides. Moreover, we must remember that consumers have the option of limiting pesticide exposure by purchasing particular, often more expensive, products (e.g., organic produces, bottled water). Therefore, one must recognize that consumers have the opportunity to make most of their money-health trade off privately. Again, this suggests that there is no strong argument for public intervention. Instead, public intervention prevents the freedom of choice, and the heterogeneity of consumers' tastes and risk preferences from being expressed on the market.

Therefore, we argue the rationale for government intervention in the regulation of pesticides should be better articulated. Obviously, a thorough discussion of government intervention should also address the possible externalities of the health effects of pesticides through the collective health 
system, as well as the possible role of the government through the development of research programs and of information campaigns.

\subsection{Risk perception}

Despite decades of research about pesticides, there is still high uncertainty about health effects of pesticides. It is well known that the toxicological studies based on animals require strong extrapolative assumptions. Epidemiological studies that we reviewed in section 2 are often sporadic and they often reveal disagreement; indeed we have seen that it happens most often that some studies find a significant effect while other studies do not find any effect. In addition, pesticides involve complex cumulative and synergetic effects that are seldom accounted for. Also, we recall that pesticide regulation is a high stake and politically sensitive issue, and there is often concern about possible conflict of interests faced by scientists leading the studies. As a result of these observations, we can hardly expect lay people like farmers or consumers, to be well informed and confident in their beliefs about the health effects due to pesticides.

To illustrate possible problems of information about health risks due to pesticides, we briefly summarize the controversies about the regulation of Alar, a pesticide long used when growing apples in the US. We use the summary provided by Kuran and Sunstein (1999). In 1989, preliminary toxicological results showed that rodents exposed to Alar have a higher than normal incidence of tumors. On the basis of this study the Natural Resources Defense Council (NRDC) made a series of pessimistic allegations, and a television show (i.e., 60 Minutes) publicized those allegations. This instigated public outcry, including actress Meryl Streep, who founded an activist group called "Mothers and Others for Pesticides Limits". The EPA then reviewed the allegations concluding that the risk was largely exaggerated by NRDC. Nevertheless, many people treated apples as highly toxic substances, and the demand for apples plummeted. The damage to the apple industry was enormous; in the Washington State alone it was about US\$125 million in losses in half a year. Moreover, EPA eventually developed further risk assessment studies and concluded that the risk was even lower than initially estimated in its first study, and about lower by a factor 60 compared to the NRDC allegations. A 1991 Science editorial stated that "a clearly dubious report about possible carcinogenicity by a special interest group was hyped by a news organization without the simplest checks on its reliability or documentation". Finally, a United Nation report concluded that Alar is not dangerous to people.

We believe that this story is symptomatic of some problems that may arise under high uncertainty conditions. The public lacks information about pesticide risks. The risks are small, and small risks are usually overestimated. Chemical risks are also overestimated compared to natural risks. Moreover, food is a special good, which may trigger special emotion and may explain over-reaction to arrival of information. Availability heuristics also play a role when the risk is made salient and popular. Besides, scientific complexity and trust issues in experts and public authorities may make it difficult to inform the public, and mitigate warning efforts. With an important gap of knowledge between experts and the public, what should the regulator do?

This question is considered by Portney's (1992) dilemma of Happyville, an imaginary society where people believe that the drinking water is contaminated while all experts agree it is harmless. Moreover, any attempt to inform people that the water is safe has had no effect. People remain 
anxious and they urge the Director of the Environmental Protection agency of Happyville to invest in a water cleanup technology. What should the Director do? The answer may be framed as a choice between populism and paternalism. A populist Director would invest a cleanup technology on the ground that worried people would "feel" protected. This is consistent with the usual welfarist approach. But a paternalistic Director computing the benefit using experts' beliefs would not invest in a cleanup technology on the ground that there is an opportunity cost of preventing a phantom risk; in other words, one could save more lives by preventing other risks. The choice is difficult. We must add, moreover, that this choice may be even more subtle because it must account for the citizens' behavioral responses to the policy. Indeed, Salanie and Treich (2009) showed that it may well be optimal for a paternalist Director to invest as well (i.e., like the populist) in the cleanup technology. The reason is an "encouragement effect" that leads citizens to increase their risk exposure (which is judged too low from the paternalistic Director viewpoint). Going back to the Alar example, this "encouragement effect" means that a paternalistic regulator may want to over invest in safety under pessimistic risk beliefs in order to mitigate the decrease in the demand of apples. This may well provide a new justification for pesticide regulation. But how to treat this paternalistic justification within BCA is a difficult question. Indeed, this justification for public intervention is not consistent with standard preference-based methods in economics.

\section{Conclusions}

We have provided two literature reviews on recent scientific findings on health effects and on preference valuation of health risks related to pesticides use, and a review and discussion of policies related to pesticides and difficulties of evaluating them. Central to our reviews have been the critical discussions of the different findings.

Our health literature review showed that most research focused on individuals with direct exposure to pesticides, e.g. farmers. Since research on people with indirect exposure was harder to find, and since most individuals belong to this group, more research should be conducted analyzing the potential health effects of pesticides on consumers and/or people with non-direct contact to pesticides. Our review also shows that for many of the health outcomes results are ambiguous; some studies find evidence of pesticides exposure leading to health impairments, whereas other do not. Further, a weakness in the literature on pesticides exposure and health effects is that many studies are based on the same AHS data set. Since context and geographical conditions may influence results, future studies on other data sources will provide important information about whether the findings based on the AHS can be confirmed or rejected.

In our review of the literature on individuals' preferences to reduce pesticides risks we found a large heterogeneity in the goods used and monetary values estimated. Based on our review we conclude that the main objective of the studies eliciting individual preferences, with some few exceptions, has not been to estimate WTP that can be used for policy purpose, e.g. in a BCA, but to examine whether individuals have a positive WTP for produce with less pesticides, or for organic or non-GM produce. This suggests that these studies focus largely on a marketing/brand/sales perspective rather than public health perspective. We also found that a difference between the health and WTP literature was that whereas the former focused on individuals with direct exposure to pesticides, the 
latter focused on those with non-direct exposure, such as consumers. On the one hand this focus arguably makes sense from a general welfare analysis perspective, since the number of individuals exposed among consumers and the public is substantially larger than direct exposed individuals. On the other hand, the evidence of health effects from pesticides among those who are not directly exposed, e.g. from pesticide residue in food, is sometimes weak or non-existing, which suggests individual WTP is based on uninformed risk levels.

Finally, in the previous section, we have briefly reviewed pesticides policies. We have indicated that existing policies are often based on a "de minimis risk" approach, and as a result they may not be consistent with economic analysis. Moreover, the rationale for pesticide regulation must be clarified. Indeed, benefits and costs related to pesticides use on farmers or on consumers essentially have a private nature, so that the very existence of market failures is not clear. We have also discussed the issue of risk perceptions. Empirical evidence indeed suggests that consumers have different perceptions about health risks from those held by our best scientific experts or by our policy makers. Yet, how to treat this divergence of risk perceptions within BCA is not clear.

Our final observation is that our reviews, which involve highly specialized research in different disciplines, also illustrate that interactions across disciplines are limited. This observation is exemplified by the different scope of the studies in our reviews. Indeed, studies in health are typically concerned with pesticide-specific effects on farmers while studies in economics are typically concerned with nonspecified pesticide effects on consumers. This relates to Zilberman and Millock (1997)'s observation that pesticide policies would improve if economic literacy among natural scientists and policymakers would increase. Interestingly, Zilberman and Millock (1997) also observe that pesticide regulation at EPA are typically separated into two units, one for risk assessment and the other for economics (and we note that a similar separation holds for the regulation of chemicals in the European Union). Arguably, this institutional organization of the policy evaluation process does not favor interdisciplinary collaboration. We thus conclude by recalling that we typically view BCA as way to incorporate knowledge from a variety of natural and health sciences, and to determine trade-offs with economic costs across various policy options. Our paper should thus be seen as a modest step toward such an interdisciplinary research effort that may help to address the immense challenge posed by pesticides regulation.

\section{Acknowledgments}

Financial support from AEAG (Agence de l'Eau Adour-Garonne) and IDEI (Institut d'Economie Industrielle) is gratefully acknowledged. The authors would also like to express their gratitude to Glenn Blomquist, Kristian Bolin, Alban Thomas, and two anonymous reviewers for their helpful comments on earlier drafts. The usual disclaimers apply. 


\section{References}

Abdel Rasoul, G. M., M. E. Abou Salem, A. A. Mechael, O. M. Hendy, D. S. Rohlman, and A. A. Ismail: 2008, 'Effects of occupational pesticide exposure on children applying pesticides'. Neurotoxicology 29(5), 833-838.

Acosta-Maldonado, B., B. Sánchez-Ramírez, S. Reza-López, and M. Levario-Carrillo: 2009, 'Effects of exposure to pesticides during pregnancy on placental maturity and weight of newborns: a cross-sectional pilot study in women from the Chihuahua State, Mexico'. Human and Experimental Toxicology 28(8), 451-459.

Adler, M. D.: 2005, 'Against individual risk: A sympathetic critique of risk assessment'. University of Pennsylvania Law Review 153, 1121-1249.

Ahamed, M., M. Anand, A. Kumar, and M. K. J. Siddiqui: 2006, 'Childhood aplastic anaemia in Lucknow, India: incidence, organochlorines in the blood and review of case reports following exposure to pesticides'. Clinical Biochemistry 39(7), 762-766.

Akgüngör, S., B. Miran, and C. Abay: 2001, 'Consumer Willingness to Pay for Food Safety Labelsin Urban Turkey: A Case Study of Pesticide Residues in Tomatoes'. Journal of International Food \& Agribusiness Marketing 12(1), 91-107.

Akkina, J. E., J. S. Reif, T. J. Keefe, and A. M. Bachand: 2004, 'Age at natural menopause and exposure to organochlorine pesticides in Hispanic women'. Journal of Toxicology and Environmental Health, Part A 67(18), 1407-1422.

Al-Hassan, R., J. B. D. Jatoe, and I. S. Egyir: 2010, 'Biopesticides in Ghana: Vegetable Farmers' Perception and Willingness to Pay'. The IUP Journal of Agricultural Economics 7(4), 17-32.

Alavanja, M., M. Dosemeci, C. Samanic, J. Lubin, C. Lynch, C. Knott, J. Barker, J. Hoppin, D. Sandler, J. Coble, K. Thomas, and A. Blair: 2004, 'Pesticides and Lung Cancer Risk in the Agricultural Health Study Cohort'. American Journal of Epidemiology 160(9), 876-885.

Alavanja, M., C. Samanic, M. Dosemeci, J. Lubin, R. Tarone, C. Lynch, C. Knott, K. Thomas, J. Hoppin, J. Barker, J. Coble, D. Sandler, and A. Blair: 2003, 'Use of Agricultural Pesticides and Prostate Cancer Risk in the Agricultural Health Study Cohort'. American Journal of Epidemiology 157(9), 800-814.

Aminov, Z., R. F. Haase, M. Pavuk, and D. O. Carpenter: 2013, 'Analysis of the effects of exposure to polychlorinated biphenyls and chlorinated pesticides on serum lipid levels in residents of Anniston, Alabama'. Environmental Health 12(1), 108.

Andersen, H. R., C. Wohlfahrt-Veje, C. Dalgård, L. Christiansen, K. M. Main, C. Nellemann, P. Grandjean, et al.: 2012, 'Paraoxonase 1 polymorphism and prenatal pesticide exposure associated with adverse cardiovascular risk profiles at school age'. PloS One 7(5), e36830.

Andersson, H.: 2005, 'The Value of Safety as Revealed in the Swedish Car Market: An Application of the Hedonic Pricing Approach'. Journal of Risk and Uncertainty 30(3), 211-239.

Andersson, H. and N. Treich: 2011, Handbook in Transport Economics, Chapt. The Value of a Statistical Life, pp. 396-424. Cheltenham, UK: Edward Elgar. 
Andreotti, G., L. Beane, L. Hou, J. Coble, J. Rusiecki, J. Hoppin, D. Silverman, and M. Alavanja: 2009, 'Agricultural Pesticide Use and Pancreatic Cancer Risk in the Agricultural Health Study Cohort'. International Journal of Cancer 124(10), 2495-2500.

Andreotti, G., L. Hou, L. Beane, R. Mahajan, S. Koutros, J. Coble, J. Lubin, A. Blair, J. Hoppin, and M. Alavanja: 2010, 'Body mass index, agricultural pesticide use, and cancer incidence in the Agricultural Health Study cohort'. Cancer Causes Control 21(1), 1759-1775.

Arbuckle, T. and L. Sever: 1998, 'Pesticide Exposure and Fetal Death: A Review of the Epidemiologic Literature'. Critical Reviews in Toxicology 28(3), 229-270.

Arbuckle, T. E., Z. Lin, and L. S. Mery: 2001. 'An exploratory analysis of the effect of pesticide exposure on the risk of spontaneous abortion in an Ontario farm population'. Environmental Health Perspectives 109(8), 851.

Atkinson, S. E. and R. Halvorsen: 1990, 'The Valuation of Risks to Life: Evidence from the Market for Automobiles'. Review of Economics and Statistics 72(1), 133-136.

Atreya, K., F. H. Johnse, and B. K. Sitaula: 2012, 'Health and environmental costs of pes- ticide use in vegetable farming in Nepal'. Environment, Development \& Sustainability 14, 477-493.

Azmi, A., S. Naqvi, A. Azmi, and M. Aslam: 2006, 'Effect of pesticide residues on health and different enzyme levels in the blood of farm workers from Gadap (rural area) Karachi-Pakistan'. Chemosphere 64(1), 1739-1744.

Balcombe, K., A. Chalak, and I. Fraser: 2009, 'Model selection for the mixed logit with Bayesian estimation'. Journal of Environmental Economics and Management 57, 226-237.

Balcombe, K., A. Bailey, A. Chalak, and I. Fraser: 2007, 'Bayesian Estimation of Willingness-to-pay Where Respondents Mis-report Their Preferences'. Oxford Bulletin of Economics and Statistics 69(3), 413-437.

Baldi, I., L. Filleul, B. Mohammed-Brahim, C. Fabrigoule, J.F. Dartigues, S. Schwall, J.P. Drevet, R. Salamon, and P. Brochard: 2001, 'Neuropsychologic effects of long-term exposure to pesticides: results from the French Phytoner study'. Environmental Health Perspectives 109 (8), 839.

Balluz, L., R. Philen, J. Brock, K. Falter, M. Kiefer, R. Hart, and R. Hill: 2000, 'Health Complaints Related to Pesticide Stored at a Public Health Clinic'. Environmental Research 82(1), 1-6.

Baranska, M., L. Van Amelsvoort, S. Birindelli, S. Fustinoni, E. Corsini, J. Liesivuori, and H. Van Loveren: 2008, 'Association of pesticide exposure, vaccination response, and interleukin-1 gene polymorphisms'. Human and Experimental Toxicology 27(9), 709-713.

Baris, D., D. T. Silverman, L. M. Brown, G. M. Swanson, R. B. Hayes, A. G. Schwartz, P. A. Stewart, et al: 2004, 'Occupation, pesticide exposure and risk of multiple myeloma'. Scandinavian Journal of Work, environment and health 215-222.

Barry, K. H., S. Koutros, G. Andreotti, D. P. Sandler, L. A. Burdette, M. Yeager, S. I. Berndt, et al: 2012, 'Genetic variation in nucleotide excision repair pathway genes, pesticide exposure and prostate cancer risk'. Carcinogenesis 33(2), 331-337.

Bateman, I. J., R. T. Carson, B. Day, M. Hanemann, N. Hanley, T. Hett, M. Jones-Lee, G. Loomes, S. Mourato, Özdemiro'glu, D. W. Pearce, R. Sugden, and J. Swanson: 2002, Economic Valuation with Stated Preference Techniques: A Manual. Cheltenham, UK: Edward Elgar. 
Beane, L., M. Bonner, A. Blair, J. Hoppin, D. Sandler, J. Lubin, M. Dosemeci, C. Lynch, C. Knott, and M. Alavanja: 2005, 'Cancer Incidence among Male Pesticide Applicators in the Agricultural Health Study Cohort Exposed to Diazinon'. American Journal of Epidemiology 162(11), 1070-1079.

Beane Freeman, L., J. Rusiecki, J. Hoppin, J. Lubin, S. Koutros, G. Andreotti, S. Hoar Zahm, C. Hines, J. Coble, F. Barone-Adesi, J. Sloan, D. Sandler, A. Blair, and M. Alavanja: 2011, 'Atrazine and Cancer Incidence Among Pesticide Applicators in the Agricultural Health Study (1994-2007)'. Environmental Health Perspectives 119(9), 1253-1259.

Beard, J., T. Sladden, G. Morgan, G. Berry, L. Brooks, and A. McMichael: 2003, 'Health Impacts of Pesticide Exposure in a Cohort of Outdoor Workers'. Environmental Health Perspectives 111(5), 724-730.

Beard, J., D. Umbach, J. Hoppin, M. Richards, M. Alavanja, A. Blair, D. Sandler, and F. Kamel: 2011, 'Suicide and Pesticide Use among Pesticide Applicators and Their Spouses in the Agricultural Health Study'. Environmental Health Perspectives 119(11), 1610-1615.

Belzer, R. R.: 1991, 'The peril and promise of risk assessment'. Regulation 47, 40-49.

Bernard, J. C. and D. J. Bernard: 2010, 'Comparing Parts with the Whole: Willingness to Pay for Pesticide-Free, Non-GM, and Organic Potatoes and Sweet Corn'. Journal of Agricultural and Resource Economics 35(3), 457-475.

Berkowitz, G. S., J. G. Wetmur, E. Birman-Deych, J. Obel, R. H. Lapinski, J. H. Godbold, M. S. Wolff, et al.: 2004, 'In utero pesticide exposure, maternal paraoxonase activity, and head circumference'. Environmental Health Perspectives 112(3), 388.

Berwald, D., S. Matten and D. Widawski: 2006, 'Economic Analysis and Regulating Pesticide Biotechnology at the U.S. Environmental Protection Agency'. Regulating Agricultural Biotechnology: Economics and Policy, Natural Resource Management and Policy 30, 21-35.

Beseler, C., L. Stallones, J. Hoppin, M. Alavanja, A. Blair, T. Keefe, and F. Kamel: 2006, 'Depression and Pesticide Exposures in Female Spouses of Licensed Pesticide Applicators in the Agricultural Health Study Cohort'. Journal of Occupational and Environmental Medicine 48(10), 1005-1013.

Beseler, C., L. Stallones, J. Hoppin, M. Alavanja, A. Blair, T. Keefe, and F. Kamel: 2008, 'Depression and Pesticide Exposures among Private Pesticide Applicators Enrolled in the Agricultural Health Study'. Environmental Health Perspectives 116(12), 1713-1719.

Bhanti, M. and A. Taneja: 2007, 'Contamination of vegetables of different seasons with organophosphorous pesticides and related health risk assessment in northern India'. Chemosphere 69(1), 63-68.

Blair, A. and S. Hoar Zahm: 1995, 'Agricultural Exposures and Cancer'. Environmental Health Perspectives 103(8), 205-208.

Boardman, A.E., D.H. Greenberg, A.R. Vining, and D.L. Weimer: 2011, Cost-Benefit Analysis: Concepts and Practice, $4^{\text {th }}$ edition, Pearson.

Boers, D., L. van Amelsvoort, C. Colosio, E. Corsini, S. Fustinoni, L. Campo, H. Van Loveren, et al: 2008, 'Asthmatic symptoms after exposure to ethylenebisdithiocarbamates and other pesticides in the Europit field studies'. Human and Experimental Toxicology 27(9), 721-727. 
Bosma, H., M. P. J. van Boxtel, R. W. H. M. Ponds, P. J. Houx, and J. Jolles: 2000, 'Pesticide exposure and risk of mild cognitive dysfunction'. The lancet 356(9233), 912-913.

Bouchard, M., J. Chevrier, K. Harley, K. Kogut, M. Vedar, N. Calderon, C. Trujillo, C. Johnson, A. Bradman, D. Boyd Barr, and B. Eskenazi: 2011, 'Prenatal Exposure to Organophosphate Pesticides and IQ in 7-Year-Old Children'. Environmental Health Perspectives 119(8), 1189-1195.

Boucher, O., M. N. Simard, G. Muckle, F. Rouget, P. Kadhel, H. Bataille, S. Cordier, et al.: 2013, 'Exposure to an organochlorine pesticide (chlordecone) and development of 18-month-old infants'. Neurotoxicology 35, $162-168$.

Brender, J. D., M. Felkner, L. Suarez, M. A. Canfield, and J. P. Henry: 2010, 'Maternal pesticide exposure and neural tube defects in Mexican Americans'. Annals of Epidemiology 20(1), 16-22.

Brody, J. G., A. Aschengrau, W. McKelvey, R. A. Rudel, C. H. Swartz, and T. Kennedy: 2004, 'Breast cancer risk and historical exposure to pesticides from wide-area applications assessed with GIS'. Environmental Health Perspectives 112(8), 889.

Buczynska, A. and I. Szadkowska: 2005, 'Identification of Heath Hazards to Rural Popula- tion Living near Pesticide Dump Sites in Poland'. International Journal of Occupational Medicine and Environmental Health 18(4), 331-339.

Burns, J., P. Williams, O. Sergeyev, S. Korrick, M. Lee, B. Revich, L. Altshul, J. Del Prato, O. Humblet, D. Patterson, W. Turner, M. Starovoytov, and R. Hauser: 2012, 'Serum Concentrations of Organochlorine Pesticides and Growth among Russian Boys'. Environmental Health Perspectives 120(2), 303-308.

Canavari, M. and R. M. J. Nayga: 2009, 'On consumers' willingness to purchase nutritionally enhanced genetically modified food'. Applied Economics 41, 125-137.

Canavari, M., G. Nocella, and R. Scarpa: 2005, 'Stated Willingness-to-Pay for Organic Fruit and Pesticide Ban: An Evaluation Using Both Web-Based and Face-to-Face Interviewing'. Journal of Food Products Marketing 11(3), 107-134.

Carreon, T., M. Butler, A. Ruder, M. Waters, K. Davis-King, G. Calvert, P. Schulte, B. Connally, E. Ward, W. Sanderson, E. Heineman, J. Mandel, R. Lorton, D. Reding, K. Rosenman, and G. Talaska: 2005, 'Gliomas and Farm Pesticide Exposure in Women: The Upper Midwest Health Study'. Environmental Health Perspectives 113(5), $546-551$.

Carson, R.: 1962, Silent Spring. Boston: Houghton Mifflin.

Cecchi, A., M. Rovedatti, G. Sabino, and G. Magnarelli: 2012, 'Environmental exposure to organophosphate pesticides: Assessment of endocrine disruption and hepatotoxicity in pregnant women'. Ecotoxicology and Environmental Safety 80, 280-287.

Chalak, A., K. Balcombe, A. Bailey, and I. Fraser: 2008, 'Pesticides, Preference Heterogeneity and Environmental Taxes'. Journal of Agricultural Economics 59(3), 537-554.

Chevrier, J., B. Eskenazi, N. Holland, A. Bradman, and D. B. Barr: 2008, 'Effects of exposure to polychlorinated biphenyls and organochlorine pesticides on thyroid function during pregnancy'. American Journal of Epidemiology 168(3), 298-310. 
Cocco, P.: 2002, 'On the rumors about the silent spring. Review of the scientific evidence linking occupational and environmental pesticide exposure to endocrine disruption health effects'. Cadernos De Saúde Pública / Ministério Da Saúde 18(2), 379-402.

Cockburn, M., P. Mills, X. Zhang, J. Zadnick, D. Goldberg, and B. Ritz: 2011, 'Prostate cancer and ambient pesticide exposure in agriculturally intensive areas in California'. American Journal of Epidemiology 173(11), 1280-1288.

Corder, E. H., and G. D. Mellick: 2006, 'Parkinson's disease in relation to pesticide exposure and nuclear encoded mitochondrial complex I gene variants'. BioMed Research International 2006.

Cox, S., A. Niskar, V. Narayan, and M. Marcus: 2007, 'Prevalence of Self-Reported Diabetes and Exposure to Organochlorine Pesticides among Mexican Americans: Hispanic Health and Nutrition Examination Survey, $1982-$ 1984'. Environmental Health Perspectives 115(12), 1747-1752.

Cranfield, J. and E. Magnusson: 2003, 'Canadian Consumer's Willingness-To-Pay For Pesticide Free Food Products: An Ordered Probit Analysist'. International Food and Agribusiness Management Review 6(4), 13-30.

Crawford, J., J. Hoppin, M. Alavanja, A. Blair, D. Sandler, and F. Kamel: 2008, 'Hearing loss among licensed pesticide applicators in the agricultural health study'. Journal of Occupational and Environmental Medicine 50(7), 817-826.

Cropper, M. L., W. N. Evans, S. J. Berardi, M. M. Ducla-Soares, and P. R. Portney: 1992, 'The determinants of pesticide regulation: A statistical analysis of EPA decision making'. Journal of Political Economy 100, 175-197.

Cropper, M. L., J. K. Hammitt, and L. A. Robinson: 2011, 'Valuing Mortality Risk Reductions: Progress and Challenges'. Annual Review of Resource Economics 3, 313-336

Dąbrowski, S., W. Hanke, K. Polańska, T. Makowiec-Dąbrowska, and W.,Sobala: 2003, 'Pesticide exposure and birth weight: an epidemiological study in Central Poland'. Int J Occup Med Environ Health 16(1), 31-39.

Datta, R., D. Sarkar, S. Sharma, and K. Sand: 2006, 'Arsenic biogeochemistry and human health risk assessment in organo-arsenical pesticide-applied acidic and alkaline soils: An incubation study'. Science of the Total Environment 372(1), 39-48.

Dayton, S., D. Sandler, A. Blair, M. Alavanja, L. Beane, and J. Hoppin: 2010, 'Pesticide Use and Myocardial Infarction Incidence Among Farm Women in the Agricultural Health Study'. Journal of Occupational and Environmental Medicine 52(7), 693-697.

De Brito Sa Stoppelli, I.M., and S. Crestana: 2005, 'Pesticide exposure and cancer among rural workers from Bariri, Sao Paulo State, Brazil'. Environment International 31 (5), 731-738.

De Roos, A., A. Blair, J. Rusiecki, J. Hoppin, M. Svec, M. Dosemeci, D. Sandler, and M. Alavanja: 2005, 'Cancer Incidence among Glyphosate-Exposed Pesticide Applicators in the Agricultural Health Study'. Environmental Health Perspectives 113(1), 49-54.

Del Prado-Lu, J.: 2007, 'Pesticide exposure, risk factors and health problems among cutflower farmers: a cross sectional study'. Journal of Occupational Medicine and Toxicology 2(9).

Dennis, L., C. Lynch, D. Sandler, and M. Alavanja: 2010, 'Pesticide Use and Cutaneous Melanoma in Pesticide Applicators in the Agricultural Health Study'. Environmental Health Perspectives 118(6), 812-817. 
Dich, J., S. H. Zahm, A. Hanberg, and H.-O. Adami: 1997, 'Pesticides and Cancer'. Cancer Causes and Control 8(3), 420-443.

Ding, G., R., Shi, Y., Gao, Y., Zhang, M., Kamijima, K., Sakai, Y., Tian, et al.: 2012, 'Pyrethroid pesticide exposure and risk of childhood acute lymphocytic leukemia in Shanghai'. Environmental science and technology 46(24), 13480-13487.

Do Pico, G.: 1992, 'Hazardous exposure and lung disease among farm workers'. Clinics in Chest Medicine 13(2), 311-328.

Eckerman, D. A., L. S. Gimenes, R. C. de Souza, P. R. L. Galvão, P. N. Sarcinelli, and J. R. Chrisman: 2007, 'Age related effects of pesticide exposure on neurobehavioral performance of adolescent farm workers in Brazil'. Neurotoxicology and Teratology 29(1), 164-175.

Engel, L., D. Hill, J. Hoppin, J. Lubin, C. Lynch, J. Pierce, C. Samanic, D. Sandler, A. Blair, and M. Alavanja: 2005, 'Pesticide Use and Breast Cancer Risk among Farmers' Wives in the Agricultural Health Study'. American Journal of Epidemiology 161(2), 121-135.

European Food Safety Authority (EFSA), 2013, The 2010 European Union report on pesticide residues in food, EFSA Journal 2013, 11(3):3130.

EPA US: 1992, Hired Farm Workers and Well-being at Risk. US General Accounting Office Report to Congressional Requesters.

Eskenazi, B., A. R. Marks, A. Bradman, K. Harley, D. B. Bart, C. Johnson, N. P. Jewell, et al: 2007, 'Organophosphate pesticide exposure and neurodevelopment in young Mexican-American children'. Environmental Health Perspectives 792-798.

Eskenazi, B., K. Huen, A. Marks, K. Harley, A. Bradman, D. Boyd Barr, and N. Holland: 2010, 'PON1 and Neurodevelopment in Children from the CHAMACOS Study Exposed to Organophosphate Pesticides in Utero'. Environmental Health Perspectives 118(12), 1775-1781.

Everett, C. and E. Matheson: 2010, 'Biomakers of pesticide exposure and diabetes in the 1999-2004 National Health and Nutrition Examination Survey'. Environmental International 36(1), 398-401.

Eyer, P.: 1995, 'Neuropsychopathological changes by organophosphorus compounds: a review'. Human and Experimental Toxicology 14(11), 857-864.

Farr, S., J. Cai, D. Savitz, D. Sandler, J. Hoppin, and G. Cooper: 2006, 'Pesticide Exposure and Timing of Menopause'. American Journal of Epidemiology 163(8), 731-742.

Farr, S., G. Cooper, J. Cai, D. Savitz, and D. Sandler: 2004, 'Pesticide Use and Menstrual Cycle Characteristics among Premenopausal Women in the Agricultural Health Study'. American Journal of Epidemiology 160(12), 1194-1204.

Fenster, L., B. Eskenazi, M. Anderson, A. Bradman, K. Harley, H. Hernandez, D. B. Barr, et al.: 2006, 'Association of in utero organochlorine pesticide exposure and fetal growth and length of gestation in an agricultural population'. Environmental Health Perspectives 114(4), 597. 
Ferreira, J. D., A. C. Couto, M. S. Pombo-de-Oliveira, S. Koifman, and Brazilian Collaborative Study Group of Infant Acute Leukemia: 2013, 'In utero pesticide exposure and leukemia in Brazilian children< 2 years of age'. Environmental Health Perspectives 121(2), 269.

Fieten, K., H. Kromhout, D. Heederik, and B. Van Wendel: 2009, 'Pesticide Exposure and Respiratory Health of Indigenous Women in Costa Rica'. American Journal of Epidemiology 169(12), 1500-1506.

Fleming, L., O. Gomez-Marin, D. Zheng, F. Ma, and D. Lee: 2003, 'National Health Interview Survey Mortality Among US Farmers and Pesticide Applicators'. American Journal of Industrial Medicine 43(1), 227-233.

Florax, R. J., C. M. Travisi, and P. Nijkamp: 2005, 'A meta-analysis of the willingness to pay for reductions in pesticide risk exposure'. European Review of Agricultural Economics 32(4), 441-467.

Flower, K., J. Hoppin, C. Lynch, A. Blair, C. Knott, D. Shore, and D. Sandler: 2004, 'Cancer Risk and Parental Pesticide Application in Children of Agricultural Health Study Participants'. Environmental Health Perspectives 112(5), 631-635.

Fong, C. S., R. M. Wu, J. C. Shieh, Y. T. Chao, Y. P. Fu, C. L. Kuao, and C. W. Cheng: 2007, 'Pesticide exposure on southwestern Taiwanese with MnSOD and NQO1 polymorphisms is associated with increased risk of Parkinson's disease'. Clinica Chimica Acta 378(1) 136-141.

Fowler, P. A., D. R. Abramovich, N. E. Haites, P. Cash, N. P. Groome, A. Al-Qahtani, R. G. Lea, et al.: 2007, 'Human fetal testis Leydig cell disruption by exposure to the pesticide dieldrin at low concentrations'. Human reproduction, 22(11), 2919-2927.

Freire, C., M. J. Lopez-Espinosa, M. Fernández, J. M. Molina-Molina, R. Prada, and N. Olea: 2011, 'Prenatal exposure to organochlorine pesticides and TSH status in newborns from Southern Spain'. Science of the Total Environment 409(18), 3281-3287.

Garcia, A.: 2003, 'Pesticide exposure and women's health'. American Journal of Industrial Medicine 44(6), 584594.

Garming, H. and H. Waibel: 2009, 'Pesticides and farmer health in Nicaragua: a willingness-to-pay approach to evaluation'. European Journal of Health Economics 10, 125-133.

Garry, V. F., M. Harkins, A. Lyubimov, L. Erickson, and L. Long: 2002, 'Reproductive outcomes in the women of the Red River Valley of the north. I. The spouses of pesticide applicators: pregnancy loss, age at menarche, and exposures to pesticides'. Journal of Toxicology and Environmental Health Part A, 65(11), 769-786.

Gifford, K. and J. C. Bernard: 2008, 'Factor and Cluster Analysis of Willingness to Pay for Organic and Non-GM Food'. Journal of Food Distribution Research 39(2), 26-39.

Glenk, K., C. Hall, U. Liebe, and J. Meyerhoff: 2012, 'Preferences of Scotch malt whisky consumers for changes in pesticide use and origin of barley'. Food Policy 37, 719-731.

Goldner, W., D. Sandler, F. Yu, J. Hoppin, F. Kamel, and L. Tricia: 2010, 'Pesticide Use and Thyroid Disease Among Women in the Agricultural Health Study'. American Journal of Epidemiology 171(4), 455-464.

Gomez-Marin, O., D. Zheng, W. LeBlanc, D. Lee, L. Fleming, F. Ma, T. Pitman, and D. Jane: 2004, 'Acute and Chronic Disability Among US Farmers and Pesticide Applicators: The National Health Interview Survey'. Journal of Agricultural Safety and Health 10(4), 275-285. 
Govindasamy, R., M. DeCongelio, and S. Bhuyan: 2005, 'An Evaluation of Consumer Willingness to Pay for Organic Produce in the Northern U.S.'. Journal of Food Products Marketing 11(4), 3-20.

Govindasamy, R., J. Italia, and A. Adelaja: 2001, 'Predicting Willingness-to-Pay a Premium for Integrated Pest Management Produce: A Logistic Approach'. Agricultural and Resource Economics Review 30(2), 151-159.

Greenburg, D., J. Rusiecki, S. Koutros, M. Dosemeci, R. Patel, C. Hines, J. Hoppin, and M. Alavanja: 2008, 'Cancer incidence among pesticide applicators exposed to captan in the Agricultural Health Study'. Cancer Causes and Control 19(10), 1401-1407.

Guodong, D., W. Pei, T. Ying, Z. Jun, G. Yu, W. Xiaojin, S. Xiaoming, et al.: 2012, 'Organophosphate pesticide exposure and neurodevelopment in young Shanghai children'. Environmental Science and Technology 46(5), 2911-2917.

Haab, T. C. and K. E. McDonnel: 2003, Valuing Environmental and Natural Resources: The Econometrics of NonMarket Valuation. Cheltenham, UK: Edward Elgar.

Haghiri, M., J. E. Hobbs, and M. L. McNamara: 2009, 'Assessing Consumer Preferences for Organically Grown Fresh Fruit and Vegetables in Eastern New Brunswick'. International Food and Agribusiness Review 12(4), 81-100.

Haghiri, M. and M. L. McNamara: 2007, 'Predicting Consumers' Acceptability of Pesticide-Free Fresh Produce in Canada's Maritime Provinces: A Probit Analysis'. Journal of International Food \& Agribusiness Marketing 19(4), 45-59.

Hamilton, S. F., D. L. Sunding, and D. Zilberman: 2003, 'Public goods and the value of product quality regulations: the case of food safety'. Journal of Public Economics 87, 799-817.

Hammitt, J. K. and J. D. Graham: 1999, 'Willingness to Pay for Health Protection: Inadequate Sensitivity to Probability?'. Journal of Risk and Uncertainty 18(1), 33-62.

Hammitt, J. K. and K. Haninger: 2010, 'Valuing fatal risks to children and adults: Effects of disease, latency, and risk aversion'. Journal of Risk and Uncertainty 40, 57-83.

Hancock, D. B., E. R. Martin, G. M. Mayhew, J. M. Stajich, R. Jewett, M. A,Stacy, W. K. Scott, et al: 2008, 'Pesticide exposure and risk of Parkinson's disease: a family-based case-control study'. Bmc Neurology 8(1), 6.

Harari, R., J. Julvez, K. Murata, D. Barr, D. Bellinger, F. Debes, and P. Grandjean: 2010, 'Neurobehavioral Deficits and Increased Blood Pressure in School-Age Children Prenatally Exposed to Pesticides'. Environmental Health Perspectives 118(6), 890-896.

Hardell, L., M. Eriksson, and M. Nordström: 2002, 'Exposure to pesticides as risk factor for non-Hodgkin's lymphoma and hairy cell leukemia: pooled analysis of two Swedish case-control studies'. Leukemia and Lymphoma 43(5), 1043-1049.

Harley, K. G., K. Huen, R. A. Schall, N. T. Holland, A. Bradman, D. B. Barr, and B. Eskenazi: 2011, 'Association of organophosphate pesticide exposure and paraoxonase with birth outcome in Mexican-American women'. PLoS One 6(8), e23923.

Hernández, A. F., B. Mackness, L. Rodrigo, O. López, A. Pla, F. Gil, M. I. Mackness, et al.: 2003, 'Paraoxonase activity and genetic polymorphisms in greenhouse workers with long term pesticide exposure'. Human and Experimental Toxicology 22(11), 565-574. 
Hernández, A. F., I. Casado, G. Pena, F. Gil, E. Villanueva, and A. Pla: 2008, 'Low level of exposure to pesticides leads to lung dysfunction in occupationally exposed subjects'. Inhalation toxicology 20(9), 839-849.

Hjollund, N. H., J. P. Bonde, E. Ernst, S. Lindenberg, A. N. Andersen, and J. Olsen: 2004, 'Pesticide exposure in male farmers and survival of in vitro fertilized pregnancies'. Human Reproduction, 19(6), 1331-1337.

Hong, S. Y., D. S., Jeong, H. W., Gil, J. O., Yang, E. Y., Lee, and S. Y. Hong, 2009: 'The estimation of pesticide exposure in depression scores: in case of Korean orchard farmers'. Journal of Pest Science 82(3), 261-265.

Hoppin, J., D. Umbach, G. Kullman, P. Henneberger, S. London, M. Alavanja, and D. Sandler: 2007a, 'Pesticides and other agricultural factors associated with self-reported farmer's lung among farm residents in the Agricultural Health Study'. Ocupational and Environmental Medicine 64(1), 334-342.

Hoppin, J., D. Umbach, S. London, M. Alavanja, and D. Sandler: 2002, 'Chemical Predictors of Wheeze among Farmer Pesticide Applicators in the Agricultural Health Study'. American Journal of Respiratory and Critical Care Medicine 165(1), 683-689.

Hoppin, J., D. Umbach, S. London, P. Henneberger, G. Kullman, M. Alavanja, and D. Sandler: 2007b, 'Pesticides and atopic and non-atopic asthma among farm women in the Agricultural Health Study'. American Journal of Respiratory and Critical Care Medicine 177(1), 11-18.

Hoppin, J., D. Umbach, S. London, P. Henneberger, G. Kullman, J. Coble, M. Alavanja, L. Beane, and D. Sandler: 2009, 'Pesticide use and adult-onset asthma among male farmers in the Agricultural Health Study'. European Respiratory Journal 34(6), 1296.

Hoppin, J., D. Umbach, S. London, C. Lynch, M. Alavanja, and D. Sandler: 2006, 'Pesticides associated with Wheeze among Commercial Pesticide Applicators in the Agricultural Health Study'. American Journal of Epidemiology 163(12), 1129-1137.

Hoppin, J., M. Valcin, P. Henneberger, G. Kullman, D. Umbach, S. London, M. Alavanja, and D. Sandler: 2007c, 'Pesticide Use And Chronic Bronchitis Among Farmers in the Agricultural Health Study'. American Journal of Industrial Medicine 50(12), 969-979.

Hou, L., W. J. Lee, J. Rusiecki, J. A. Hoppin, A. Blair, M. Bonner, M. C. Alavanja, et al: 2004, 'Pendimethalin exposure and cancer risk among pesticide applicators: a report from the US-based agricultural health study'. Annals of Epidemiology 14(8), 608.

Huang, C. L., K. Kan, and T. Fu: 2000, 'Joint Estimation of Consumer Preferences and Willingness-to-pay for Food Safety’. Academia Economic Papers 28(4), 429-449.

Hughes Barry, K., S. Koutros, S. Berndt, G. Andreotti, J. Hoppin, D. Sandler, L. Bur- dette, M. Yeager, L. Beane Freeman, J. Lubin, X. Ma, T. Zheng, and M. Alavanja: 2011, 'Genetic Variation in Base Excision Repair Pathway Genes, Pesticide Exposure, and Prostate Cancer Risk'. Environmental Health Perspectives 119(12), 1726-1732.

Jones-Lee, M. W.: 1976, 'The Value of Life: An Economic Analysis'. Chicago, IL, USA: University of Chicago Press.

Jurewicz, J., W. Hanke, T. Makowiec-Dąbrowska, and W. Sobala: 2005, 'Exposure to pesticides and heavy work in greenhouses during pregnancy: does it affect birth weight?'. International Archives of Occupational and Environmental Health 78(5), 418-426. 
Kamel, F., L. Engel, B. Gladen, J. Hoppin, M. Alavanja, and D. Sandler: 2005, 'Neu- rologic symptoms in Licensed Private Pesticide Applicators in the Agricultural Health Study'. Environmental Health Perspectives 113(7), 877882.

Kamel, F., A. Rowland, L. Park, K. Anger, D. Baird, B. Gladen, T. Moreno, L. Stallone, and D. Sandler: 2003, 'Neurobehavioral Performance and Work Experience in Florida Farmworkers'. Environmental Health Perspectives 111(14), 1765-1772.

Kamel, F., C. Tanner, D. Umbach, J. Hoppin, M. Alavanja, A. Blair, K. Comyns, S. Goldman, M. Korell, J. Langston, G. Ross, and D. Sandler: 2006, 'Pesticide Exposure and Self-reported Parkinson's Disease in the Agricultural Health Study'. American Journal of Epidemiology 165(4), 364-374.

Kang, D., S. Park, L. Beane, C. Lynch, C. Knott, D. Sandler, J. Hoppin, M. Dosemeci, J. Coble, J. Lubin, A. Blair, and M. Alavanja: 2008, 'Cancer incidence among pesticide applicators exposed to trifluralin in the Agricultural Health Study'. Environmental Research 107(1), 271-276.

Karunanayake, C. P., J. J. Spinelli, J. R. McLaughlin, J. A. Dosman, P. Pahwa, and H. H. McDuffie: 2012, 'Hodgkin lymphoma and pesticides exposure in men: a Canadian case-control study'. Journal of Agromedicine 17(1), 30-39.

Kesavachandran, C., M. Pathak, M. Fareed, V. Bihari, N. Mathur, and A. Srivastava: 2009, 'Health risks of employees working in pesticide retail shops: an exploratory study'. Indian Journal of Occupational and Environmental Medicine 13(3), 121-126.

Khan, D., I. Hashmi, W. Mahjabeen, and T. Naqvi: 2010, 'Monitoring health implications of pesticide exposure in factory workers in Pakistan'. Environmental Monitoring and Assessment 168(1), 231-240.

Khan, M.: 2009, 'Economic Evaluation of Health Cost of Pesticide Use: Willingness to Pay Method'. Pakistan Development Review 48(4), 459-470.

Kling, C. L., D. J. Phaneuf, and J. Zhao: 2012, 'From Exxon to BP: Has Some Number Become Better than No Number?'. Journal of Economic Perspectives 26(4), 3-26.

Kirrane, E., J. Hoppin, F. Kamel, D. Imbach, W. Boyes, A. DeRoos, M. Alavanja, and D. Sandler: 2005, 'Retinal Degeneration and Other Eye Disorders in Wives of Farmer Pesticide Applicators Enrolled in the Agricultural Health Study'. American Journal of Epidemiology 161(11), 1020-1029.

Kokouva, M., N. Bitsolas, G. Hadjigeorgiou, G. Rachiotis, N. Papadoulis, C. Hadjichristodoulou: 2011, 'Pesticide exposure and lymphohaematopoietic cancers: a case-control study in an agricultural region (Larissa, Thessaly, Greece)'. BMC Public Health 11(5).

Koutros, S., C. Lynch, X. Ma, W. Lee, J. Hoppin, C. Christensen, G. Andreotti, L. Beane, J. Rusiecki, L. Hou, D. Sandler, and M. Alavanja: 2009, 'Aromatic amine pesticide use and human cancer risk: results from the U.S. Agricultural Health Study'. International Journal of Cancer 124(5), 1206-1212.

Kuran, T. and C. R. Sunstein: 1999, 'Availability cascades and risk regulation'. Stanford Law Review 51, 683-768.

Lacasaña, M., I. López-Flores, M. Rodríguez-Barranco, C. Aguilar-Garduño, J. Blanco-Muñoz, O. Pérez-Méndez, M. E. Cebrian, et al.: 2010, 'Association between organophosphate pesticides exposure and thyroid hormones in floriculture workers'. Toxicology and Applied Pharmacology 243(1), 19-26. 
Lacasaña, M., I. López-Flores, M. Rodríguez-Barranco, C. Aguilar-Garduño, J. Blanco-Muñoz, O. Pérez-Méndez, M. E. Cebrian, et al.: 2010b, 'Interaction between organophosphate pesticide exposure and PON1 activity on thyroid function'. Toxicology and applied pharmacology 249(1), 16-24.

Landgren, O., R. Kyle, J. Hoppin, L. Beane, J. Cerhan, J. Katzman, V. Rajkumar, and M. Alavanja: 2002, 'Pesticide exposure and risk of monoclonal gammopathy of undetermined significance in the Agricultural Health Study'. The New England Journal of Medicine 346(1), 564-569.

Lauria, L., L. Settimi, A. Spinelli, and I. Figà-Talamanca: 2006, 'Exposure to pesticides and time to pregnancy among female greenhouse workers'. Reproductive Toxicology 22(3), 425-430.

Lee, S., R. McLaughlin, M. Harnly, R. Gunier, and R. Kreutzer: 2002, 'Community exposures to airborne agricultural pesticides in California: ranking of inhalation risks'. Environmental Health Perspectives 110(12), 1175.

Lee, W., A. Blair, J. Hoppin, J. Lubin, J. Rusiecki, D. Sandler, M. Dosemeci, and M. Ala- vanja: 2004a, 'Cancer Incidence Among Pesticide Applicators Exposed to Chlorpyrifos in the Agricultural Health Study'. Journal of the National Cancer Institute 96(23), 1781-1789.

Lee, W., J. Hoppin, A. Blair, J. Lubin, M. Dosemeci, D. Sandler, and M. Alavanja: 2004b, 'Cancer Incidence among Pesticide Applicators Exposed to Alachlor in the Agricultural Health Study'. American Journal of Epidemiology 159(4), 373-380.

Lee, W. J., A. Baccarelli, M. Tretiakova, S. Gorbanev, A. Lomtev, I. Klimkina, M. Dosemeci, et al: 2006, 'Pesticide exposure and lung cancer mortality in Leningrad province in Russia'. Environment International 32(3), 412-416.

Lee, W., D. Sandler, A. Blair, C. Samanic, A. Cross, and M. Alavanja: 2007, 'Pesticide use and colorectal cancer risk in the Agricultural Health Study'. International Journal of Cancer 121(2), 339-346.

Levario-Carrillo, M., D. Amato, P. Ostrosky-Wegman, C. González-Horta, Y. Corona, and L. H. Sanin: 2004, 'Relation between pesticide exposure and intrauterine growth retardation'. Chemosphere 55(10), 1421-1427.

Li, X., Y. Gan, X. Yang, J. Zhou, J. Dai, and M. Xu: 2008, 'Human health risk of organochlorine pesticides (OCPs) and polychlorinated biphenyls (PCBs) in edible fish from Huairou Reservoir and Gaobeidian Lake in Beijing, China'. Food Chemistry 109(1), 348-354.

López, O., A. F. Hernández, L. Rodrigo, F. Gil, G. Pena, J. L. Serrano, A. Pla, et al.: 2007, 'Changes in antioxidant enzymes in humans with long-term exposure to pesticides'. Toxicology Letters 171(3), 146-153.

Loureiro, M. L., J. L. McCluskey, and R. C. Mittelhammer: 2002, 'Will Consumers Pay a Premium for Eco-labeled Apples'. Journal of Consumer Affairs 36(2), 203-219.

Lynch, S., R. Mahajan, L. Beane, J. Hoppin, and M. Alavanja: 2009, 'Cancer incidence among pesticide applicators exposed to butylate in the Agricultural Health Study (AHS)'. Environmental Research 109(1), 860-868.

Lynch, S., J. Rusiecki, A. Blair, M. Dosemeci, J. Lubin, D. Sandler, J. Hoppin, C. Lynch, and M. Alavanja: 2006 , 'Cancer Incidence among Pesticide Applicators Exposed to Cyanazine in the Agricultural Health Study'. Environmental Health Perspectives 114(8), 1248-1252.

Ma, X., P. A. Buffler, R. B. Gunier, G. Dahl, M. T. Smith, K. Reinier, and P. Reynolds: 2002, 'Critical windows of exposure to household pesticides and risk of childhood leukemia'. Environmental Health Perspectives 110(9), 955. 
Maguire, K. B., N. Owens, and N. B. Simon: 2004, 'The Price Premium for Organic Babyfood: A Hedonic Analysis'. Journal of Agricultural and Resource Economics 29(1), 132-149.

Marette, S., A. Messéan, and G. Millet: 2012, 'Consumers' willingness to pay for eco- friendly apples under different labels: Evidence from a lab experiment'. Food Policy 37, 151-161.

Marks, A.R., K. Harley, A. Bradman, K. Kogut, D.B. Barr, C. Johnson, N. Calderon, B. Eskenazi: 2010, 'Organophosphate pesticide exposure and attention in young Mexican-American children: the CHAMACOS study'. Environmental Health Perspectives 118 (12), 1768-74.

Martin, S., D. Sandler, S. Harlow, D. Shore, A. Rowland, and M. Alavanja: 2002, 'Pesticide Use and PesticideRelated Symptoms Among Black Farmers in the Agricultural Health Study'. American Journal of Industrial Medicine 41(1), 202-209.

Mathur, V., P. Bhatnagar, R. G. Sharma, V. Acharya, and R. Sexana: 2002, 'Breast cancer incidence and exposure to pesticides among women originating from Jaipur'. Environment International 28(5), 331-336.

McDuffie, H., P. Punam, J. McLaughlin, J. Spinelli, S. Finchman, J. Dosman, D. Robson, L. Skinnider, and N. Choir: 2001, 'Non-Hodgkin's Lymphoma and specific Pesticide Exposures in Men: Cross-Canada Study of Pesticides and Health'. Cancer Epidemiology, Biomakres \& Prevention 10(1), 1155-1163.

Meinert, R., J. Schüz, U. Kaletsch, P. Kaatsch, and J. Michaelis: 2000. 'Leukemia and non-Hodgkin's lymphoma in childhood and exposure to pesticides: results of a register-based case-control study in Germany'. American Journal of Epidemiology 151(7), 639-646.

Mekonnen, Y., Agonafir, T.: 2002, 'Effects of Pesticide Applications on Respiratory Health of Ethiopian Farm Workers'. International Journal of Occupational and Environmental Health 8(1), 35-40.

Melkonian, S., M. Argos, B. L. Pierce, Y. Chen, T. Islam, A. Ahmed, H. Ahsan, et al.: 2011, 'A prospective study of the synergistic effects of arsenic exposure and smoking, sun exposure, fertilizer use, and pesticide use on risk of premalignant skin lesions in Bangladeshi men'. American Journal of Epidemiology 173(2), 183-191.

Mills, K., A. Blair, L. Beane, D. Sandler, and J. Hoppin: 2009, 'Pesticides and Myocardial Infarction Incidence and Mortality Among Male Pesticide applicators in the Agricultural Health Study'. American Journal of Epidemiology 170(7), 892-900.

Ministère de l'Agriculture et de la Pêche (MAP), 2009, La réduction des usages de pesticides : le plan Ecophyto 2018, Analyse, Prospective et Evaluation, Février 2009.

Montgomery, M., F. Kamel, T. Saldana, M. Alavanja, and D. Sandler: 2008, 'Incident Diabetes and Pesticide Exposure among Licensed Pesticide Applicators: Agricultural Health Study, 1993-2003'. American Journal of Epidemiology 167(10), 1235-1246.

Moon, H.-B., H.-S. Kim, M. Choi, J. Yu, and H.-G. Choi: 2009, 'Human health risk of polychlorinated biphenyls and organochlorine pesticides resulting from seafood consumption in South Korea, 2005-2007'. Food and Chemical Toxicology 47(1), 1819-1825.

Mourato, S., E. Ozdemiroglu, and V. Foster: 2000, 'Evaluating Health and Environmental Impacts of Pesticide Use: Implications for the Design of Ecolabels and Pesticide Taxes'. Environmental Science \& Technology 34(8), 14561461. 
Mozzachio, A., J. Rusiecki, J. Hoppin, R. Mahajan, R. Patel, L. Beane, and M. Ala- vanja: 2008, 'Chlorothalonil exposure and cancer incidence among pesticide applicator participants in the agricultural health study'. Environmental Research 108(1), 400-403.

Murphy, H., A. Sanusi, R. Dilts, M. Djajadisastra, N. Hirschhorn, and S. Yuliantiningsih: 1999, 'Health Effects of Pesticide Use Among Indonesian Women Farmers: Part I: Exposure and Acute Health Effects'. Journal of Agromedicine 6(3), 61-85.

Murphy, R. and D. Haith: 2007, 'Inhalation Health Risk to Golfers from Turfgrass Pesticides at Three Northeastern U.S. Sites'. Environmental Science and Technology 41(3), 1038-1043.

Nagayama, J., H. Tsuji, T. Lida, R. Nakagawa, T. Matsueda, H. Hirakawa, T. Watanabe: 2007, 'Immunologic effects of perinatal exposure to dioxins, PCBs and organochlorine pesticides in Japanese infants'. Chemosphere 67(9), S393-S398.

NAS: 1987, 'Regulating pesticides in food'. Washington DC, National Academy of Sciences.

Nielsen, T.: 2013, 'Consumer Buying Behavior of Genetically Modified Fries in Germany'. Journal of Food Products Marketing 19, 41-53.

Nielsen, S. S., R. McKean-Cowdin, F. M. Farin, E. A. Holly, S. Preston-Martin, and B. A. Mueller: 2010, 'Childhood brain tumors, residential insecticide exposure, and pesticide metabolism genes'. Environmental Health Perspectives 118(1), 144.

Ogut, S., F. Gultekin, A. N. Kisioglu, and E. Kucukoner: 2011, 'Oxidative stress in the blood of farm workers following intensive pesticide exposure'. Toxicology and industrial health 27(9), 820-825.

Orton, F., E. Rosivatz, M. Scholze, and A. Kortenkamp: 2011, 'Widely Used Pesticides with Previously Unknown Endocrine Activity Revealed as in Vitro Antiandrogens'. Environmental Health Perspectives 119(6), 794-800.

O'Leary, E. S., J. E. Vena, J. L. Freudenheim, and J. Brasure: 2004, 'Pesticide exposure and risk of breast cancer: a nested case-control study of residentially stable women living on Long Island'. Environmental Research 94(2), 134-144.

Padungtod, C., D. A. Savitz, J. W. Overstreet, D. C. Christiani, L. M. Ryan, and X. Xu: 2000, 'Occupational pesticide exposure and semen quality among Chinese workers'. Journal of occupational and Environmental Medicine 42(10), 982-992.

Pahwa, P., C. P. Karunanayake, J. A. Dosman, J. J. Spinelli, and J. R. McLaughlin: 2011, 'Soft-Tissue Sarcoma and Pesticides Exposure in Men: Results of a Canadian Case-Control Study'. Journal of Occupational and Environmental Medicine 53(11), 1279-1286.

Pahwa, P., C. P. Karunanayake, J. A. Dosman, J. J. Spinelli, H. H. McDuffie, and J. R. McLaughlin: 2012, 'Multiple myeloma and exposure to pesticides: a Canadian case-control study'. Journal of Agromedicine 17(1), 40-50.

Palis, F. G., R. J. Flor, H. Warburthon, and M. Hossain: 2006, 'Our farmers at risk: behavior and belief system in pesticide safety'. Journal of Public Health 28(1), 43-48.

Pandit, G. and S. Sahu: 2002, 'Assessment of risk to public health posed by persistent organochlorine pesticide residues in milk and milk products in Mumbai, India'. Journal of Environmental Monitoring 4(1), 182-185. 
Park, S. K., K. A. Kong, E. S. Cha, Y. J. Lee, G. T. Lee, and W. J. Lee: 2012, 'Occupational exposure to pesticides and nerve conduction studies among Korean farmers'. Archives of Environmental and Occupational Health 67(2), 7883.

Parrón, T., M. Requena, A. F. Hernández, and R. Alarcón: 2011, 'Association between environmental exposure to pesticides and neurodegenerative diseases'. Toxicology and Applied Pharmacology 256(3), 379-385.

Pearce, M. S., D. M., Hammal, M. T., Dorak, R. J., McNally, and L. Parker: 2006, 'Paternal occupational exposure to pesticides or herbicides as risk factors for cancer in children and young adults: a case-control study from the North of England'. Archives of Environmental and Occupational Health 61(3), 138-144.

Peiris-John, R. J., D. K. Ruberu, A. R. Wickremasinghe, L. A. M. Smit, and W. van der Hoek: 2002, 'Effects of occupational exposure to organophosphate pesticides on nerve and neuromuscular function'. Journal of Occupational and Environmental Medicine 44(4), 352-357.

Perry, M. J., S. A. Venners, X. Chen, X. Liu, G. Tang, H. Xing, X. Xu, et al.: 2011, 'Organophosphorous pesticide exposures and sperm quality'. Reproductive Toxicology 31(1), 75-79.

Petit, C., C. Chevrier, G. Durand, C. Monfort, F. Rouget, R. Garlantezec, and S. Cordier: 2010, 'Impact on fetal growth of prenatal exposure to pesticides due to agricultural activities: a prospective cohort study in Brittany, France'. Environmental Health 9(71).

Pimentel, D.: 2005, 'Environmental and economic costs of the application of pesticides primarily in the United States'. Environment, Development and Sustainability 7, 229-52.

Portney, P. R.: 1992, 'Trouble in Happyville'. Journal of Policy Analysis and Management 11, 131-32.

Posri, W., B. Shankar, and S. Chadbunchachai: 2007, 'Consumer Attitudes Towards and Willingness to Pay for Pesticide Residue Limit Complaint "Safe" Vegetables in Northeast Thailand'. Journal of International Food \& Agribusiness Marketing 19(1), 81-101.

Potti, A., A. W. Panwalkar, and E. Langness: 2003, 'Prevalence of pesticide exposure in young males $(</=50$ years) with adenocarcinoma of the prostate'. Journal of Carcinogenesis 2(1), 4.

Probst, L., E. Houedjofonon, H. M. Ayerakwa, and R. Haas: 2012, 'Will they buy it? The potential for marketing organic vegetables in the food vending sector to strengthen vegetable safety: A choice experiment study in three African cities'. Food Policy 37, 296-308.

Quirós-Alcalá, L., A. D. Alkon, W. T. Boyce, S. Lippert, N. V. Davis, A. Bradman, B. Eskenazi, et al.: 2011, 'Maternal prenatal and child organophosphate pesticide exposures and children's autonomic function'. Neurotoxicology 32(5), 646-655.

Rauch, S. A., J. M. Braun, D. B. Barr, A. M. Calafat, J. Khoury, M. A. Montesano, B. P. Lanphear, et al.: 2012, 'Associations of prenatal exposure to organophosphate pesticide metabolites with gestational age and birth weight'. Environmental Health Perspectives 120(7), 1055.

Rauh, V., S. Arunajadai, M. Horton, F. Perera, L. Hoepner, D. Barr, and R. Whyatt: 2011, 'Seven-Year Neurodevelopmental Scores and Prenatal Exposure to Chlorpyrifos, a Common Agricultural Pesticide'. Environmental Health Perspectives 119(8), 1196-1201. 
Rastogi, S. K., S. Tripathi, and D. Ravishanker: 2010, 'A study of neurologic symptoms on exposure to organophosphate pesticides in the children of agricultural workers'. Indian Journal of Occupational and Environmental Medicine 14(2), 54.

Recio, R., W. A. Robbins, V. Borja-Aburto, J. Moran-Martinez, J. R. Froines, R. M. Hernandez, and M. E. Cebrian: 2001. 'Organophosphorous pesticide exposure increases the frequency of sperm sex null aneuploidy'. Environmental Health Perspectives 109(12), 1237.

Recio, R., G. Ocampo-Gómez, J. Morán-Martínez, V. Borja-Aburto, M. López-Cervantes, M. Uribe, M. E. Cebrián, et al.: 2005, 'Pesticide exposure alters follicle-stimulating hormone levels in Mexican agricultural workers'. Environmental health perspectives 113(9), 1160.

Richter, E. D.: 2002, 'Acute human pesticide poisonings'. Encyclopedia of Pest Management pp. 3-6.

Roldán-Tapia, L., T. Parrón, and F. Sánchez-Santed: 2005. 'Neuropsychological effects of long-term exposure to organophosphate pesticides'. Neurotoxicology and Teratology 27(2), 259-266.

Roldan-Tapia, L., F. A. Nieto-Escamez, E. M. del Aguila, F. Laynez, T. Parron, and F. Sanchez-Santed: 2006, 'Neuropsychological sequelae from acute poisoning and long-term exposure to carbamate and organophosphate pesticides'. Neurotoxicology and Teratology 28(6), 694-703.

Ronda, E., E. Regidor, A. M. García, and V. Domínguez: 2005, 'Association between congenital anomalies and paternal exposure to agricultural pesticides depending on mother's employment status'. Journal of Occupational and Environmental Medicine 47(8), 826-828.

Rothlein, J., D. Rohlman, M. Lasarev, J. Phillips, J. Muniz, and L. McCauley: 2006, 'Organophosphate pesticide exposure and neurobehavioral performance in agricultural and nonagricultural Hispanic workers'. Environmental Health Perspectives 114(5), 691.

Rudant, J., F. Menegaux, G. Leverger, A. Baruchel, B. Nelken, Y. Bertrand, J. Clavel, et al.: 2007, 'Household exposure to pesticides and risk of childhood hematopoietic malignancies: The ESCALE study (SFCE)'. Environmental Health Perspectives 115(12), 1787.

Ruder, A. M., M. A. Waters, M. A. Butler, T. Carreón, G. M. Calvert, K. E. Davis-King, G. Talaska: 2004, 'Gliomas and farm pesticide exposure in men: the Upper Midwest Health Study'. Archives of Environmental Health: An International Journal 59(12), 650-657.

Rusiecki, J., A. De Roos, W. Lee, M. Dosemeci, J. Lubin, J. Hoppin, A. Blair, and M. Alavanja: 2004, 'Cancer Incidence Among Pesticide Applicators Exposed to Atrazine in the Agricultural Health Study'. Journal of the National Cancer Institute 96(18), 1375-1382.

Rusiecki, J., L. Hou, W. Lee, a. Blair, M. Dosemeci, J. Lubin, M. Bonner, C. Samanic, J. Hoppin, D. Sandler, and M. Alavanja: 2006, 'Cancer incidence among pesticide applicators exposed to metolachlor in the Agricultural Health Study'. International Journal of Cancer 118(1), 3118-3123.

Rusiecki, J., R. Patel, S. Koutros, L. Beane, O. Landgren, J. Bonner, Matthew adn Coble, J. Lubin, A. Blair, J. Hoppin, and M. Alavanja: 2009, 'Cancer Incidence among Pesticide Applicators Exposed to Permethrin in the Agricultural Health Study'. Environmental Health Perspectives 117(4), 581-586.

Safi, J. M.: 2002, 'Association between chronic exposure to pesticides and recorded cases of human malignancy in Gaza Governorates (1990-1999)'. Science of the total environment 284(1), 75-84. 
Salameh, P., M. Waked, I. Baldi, P. Brochard, and B. A. Saleh: 2006, 'Respiratory diseases and pesticide exposure: a case-control study in Lebanon'. Journal of Epidemiology and Community Health 60(3), 256-261.

Salanie, F. and N. Treich: 2009, 'Regulation in Happyville’. Economic Journal 537, 667-79.

Saldana, T., O. Basso, J. Hoppin, D. Baird, C. Knott, A. Blair, M. Alavanja, and D. Sandler: 2007, 'Pesticide exposure and self-reported gestational diabetes mellitus in the Agricultural Health study'. Diabetes Care 30(1), 529-534.

Saldana, T. M., O. Basso, D. D. Baird, J. A. Hoppin, C. R. Weinberg, A. Blair, D. P. Sandler, et al.: 2009, 'Pesticide exposure and hypertensive disorders during pregnancy'. Environmental Health Perspectives 117(9), 1393-1396.

Samanic, C., J. Rusiecki, M. Dosemeci, I. Hou, J. hoppin, D. Sandler, J. Lubin, A. Blair, and M. Alavanja: 2006, 'Cancer Incidence among Pesticide Applicators Ex- posed to Dicamba in the Agricultural Health Study'. Environmental Health Perspectives 114(10), 1521-1526.

Samanic, C. M., A. J. De Roos, P. A. Stewart, P. Rajaraman, M. A. Waters, and P. D. Inskip: 2008, 'Occupational exposure to pesticides and risk of adult brain tumors'. American Journal of Epidemiology 167(8), 976-985.

Sanchez-Pena, L. C., B. E. Reyes, L. Lopez-Carrillo, R. Recio, J. Morán-Martınez, M. E. Cebrian, and B. QuintanillaVega: 2004, 'Organophosphorous pesticide exposure alters sperm chromatin structure in Mexican agricultural workers'. Toxicology and Applied Pharmacology 196(1), 108-113.

Sathiakumar, N., E. Delzell, P. MacLennan, M. Anne, N. Rosenberg, H. Cheng, and S. Myers: 2004, 'A crosssectional study of triallate exposure and neurological health among workers at a pesticide manufacturing and formulating facility'. Occupational and Environmental Medicine 61(1), 936-944.

Sathyanarayana, S., O. Basso, C. Karr, P. Lozano, M. Alavanja, D. Sandler, and J. Hoppin: 2010, 'Maternal Pesticide Use and Birth Weight in the Agricultural Health Study'. Journal of Agromedicine 15(2), 127-136.

Schou, J., B. Hasler, and B. Nahrstedt: 2006, 'Valuation of Biodiversity Effects from Reduced Pesticide Use'. Integrated Environmental Assessment Management 2(2), 174-181.

Schultz, C. G., and F. R. Ferraro: 2013, 'The Impact of Chronic Pesticide Exposure on Neuropsychological Functioning'. Psychological Record 63(1).

Sekiyama, M., M. Tanaka, B. Gunawan, O. Abdoellah, and C. Watanabe: 2007, 'Pesticide Usage and Its Association with Health Symptoms among Farmers in Rural Villages in West Java, Indonesia'. Environmental Sciences 14(1), 23-33.

Shim, Y. K., S. P. Mlynarek, and E. van Wijngaarden: 2009, 'Parental exposure to pesticides and childhood brain cancer: US Atlantic coast childhood brain cancer study'. Environmental Health Perspectives 117(6), 1002.

Slager, R., J. Poole, t. LeVan, D. Sandler, M. Alavanja, and J. Hoppin: 2009, 'Rhinitis Associated with Pesticide Exposure among Commercial Pesticide Applicators in the Agricultural Health Study'. Ocuppational and Environmental Medication 66(11), 718-724.

Slovic, P.: 2000, 'The Perception of Risk'. Earthscan Publisher.

Son, H., S. Kim, J. Hang, Y. Chang, S. Park, S. Lee, D. Jacobs, and D. Lee: 2010, 'Strong associations between lowdose organochlorine pesticides and type 2 diabetes in Korea'. Environmental International 36(5), 410-414. 
Sprince, N., M. Lewis, P. Whitten, S. Reynolds, and C. Zwerling: 2000, 'Respiratory Symptoms: Associations With Pesticides, Silos, and Animal Confinement in the lowa Farm Family Health and Hazard Surveillance Project'. American Journal of Industrial Medicine 38(1), 455-462.

Stallones, L. 2006, 'Suicide and potential occupational exposure to pesticides, Colorado 1990-1999'. Journal of Agromedicine 11(3-4), 107-112.

Starks, S. E., F. Gerr, F. Kamel, C. F. Lynch, M. C. Alavanja, D. P. Sandler, and J. A. Hoppin: 2012, 'High pesticide exposure events and central nervous system function among pesticide applicators in the Agricultural Health Study'. International Archives of Occupational and Environmental Health 85(5), 505-515.

Starks, S., J. Hoppin, F. Kamel, C. Lynch, M. Jones, M. Alavanja, D. Sandler, and F. Gerr: 2012b, 'Peripheral Nervous System Function and Organophosphate Pesticide Use among Licensed Pesticide Applicators in the Agricultural Health Study'. Environmental Health Perspectives 120(4), 515-520.

Steenland, K., C. Wesseling, N. Román, I. Quirós, and J. L. Juncos: 2013, 'Occupational pesticide exposure and screening tests for neurodegenerative disease among an elderly population in Costa Rica'. Environmental Research 120, 96-101.

Strong, L., B. Thompson, G. Coronado, W. Griffith, E. Vigoren, and I. Islas: 2004, 'Health Symptoms and Exposure to Organophosphate Pesticides in Farmworkers'. American Journal of Industrial Medicine 46(1), 599-606.

Sunstein, C. R.: 2002, Risk and Reason. Cambridge University Press.

Sutoluk, Z., Z., Kekec, N., Daglioglu, and I. Hant: 2011, 'Association of Chronic Pesticide Exposure with Serum Cholinesterase Levels and Pulmonary Functions'. Archives of Environmental and Occupational Health 66(2), 95-99.

Swan, S. H.: 2006, 'Semen quality in fertile US men in relation to geographical area and pesticide exposure'. International Journal of Andrology 29(1), 62-68.

Sydorovych, O. and M. Michele: 2008, 'Valuing the Changes in Herbicide Risks Resulting from Adoption of Roundup Ready Soybeans by U.S. Farmers: A Revealed-Preference Approach'. Journal of Agricultural and Applied Economics 40(3), 777-787.

Travisi, C. M. and P. Nijkamp: 2008, 'Valuing environmental and health risk in agriculture: A choice experiment approach to pesticides in Italy'. Ecological Economics 67, 598-607.

Travisi, C. M., P. Nijkamp, and G. Vindigni: 2006, 'Pesticide risk valuation in empirical economics: a comparative approach'. Ecological Economics 56, 455-474.

True, L. P.: 1997, 'Agricultural pesticides and worker protection'. Economic Analyses at EPA pp. 303-32.

Van Bemmel, D., K. Visvanathan, L. Beane, J. Coble, J. Hoppin, and M. Alavanja: 2008, 'S-Ethyl-N,Ndipropylthiocarbamate Exposure and Cancer Incidence among Male Pesticide Applicators in the Agricultural Health Study: A Prospective Cohort'. Environmental Health Perspectives 116(11), 1541-1546.

Van Houtven, G. and M. L. Cropper: 1996, 'When is life too costly to save? The evidence from U.S. environmental regulations'. Journal of Environmental Economics and Management 30, 348-368.

Van Wijngaarden, E.: 2003. 'Mortality of mental disorders in relation to potential pesticide exposure'. Journal of Occupational and Environmental Medicine 45(5), 564-568. 
Vlastos, D., P. Stivaktakis, and D. P. Matthopoulos: 2006, 'Pesticide exposure and genotoxicity correlations within a Greek farmers' group'. International Journal of Environmental Analytical Chemistry 86(3-4), 215-223.

Viscusi, W. K. and J. E. Aldy: 2003, 'The Value of a Statistical Life: A Critical Review of Market Estimates Throughout the World'. Journal of Risk and Uncertainty 27(1), 5-76.

Wang, P., Y. Tian, X.-J. Wang, Y. Gao, R. Shi, G.-Q. Wang, G.-H. Hu, and X.-M. Shen: 2012, 'Organophosphate pesticide exposure and perinatal outcomes in Shanghai, China'. Environmental International 42, 100-104.

Ward, M. H., J. S. Colt, C. Metayer, R. B. Gunier, J. Lubin, V. Crouse, P. A. Buffler, et al.: 2009, 'Residential exposure to polychlorinated biphenyls and organochlorine pesticides and risk of childhood leukemia'. Environmental Health Perspectives 117(6), 1007-1013.

Weichenthal, S., C. Moase, and C. Peter: 2010, 'A Review of Pesticide Exposure and Cancer Incidence in the Agricultural Health Study Cohort'. Environmental Health Perspectives 118(8), 1117-1125.

Weselak, M., T. E. Arbuckle, D. T. Wigle, and D. Krewski: 2007, 'In utero pesticide exposure and childhood morbidity'. Environmental Research 103(1), 79-86.

Weselak, M., T. E. Arbuckle, D. T. Wigle, M. C. Walker, and D. Krewski: 2008, 'Pre-and post-conception pesticide exposure and the risk of birth defects in an Ontario farm population'. Reproductive Toxicology 25(4), 472-480.

Wickerham, E., B. Lozoff, J. Shao, N. Kaciroti, Y. Xia, and J. Meeker: 2012, 'Reduced birth weight in relation to pesticide mixtures detected in cord blood of full-term infants'. Environmental International 47, 80-85.

Xu, X., A. Dailey, E. Talbott, V. Ilacqua, G. Kearney, and N. Asal: 2010, 'Associations of Serum Concentrations of Organochlorine Pesticides with Breast Cancer and Prostate Cancer in US Adults'. Environmental Health Perspectives 118(1), 60-66.

Yesavage, J. A., J. Sheikh, A. Noda, G. Murphy, R. O'Hara, R. Hierholzer, J. Tinklenberg, et al.: 2004, 'Use of a VA pharmacy database to screen for areas at high risk for disease: Parkinson's disease and exposure to pesticides'. Journal of Geriatric Psychiatry and Neurology 17(1), 36-38.

Young, J. G., B. Eskenazi, E. A. Gladstone, A. Bradman, L. Pedersen, C. Johnson, N. T. Holland, et al.: 2005, 'Association between in utero organophosphate pesticide exposure and abnormal reflexes in neonates'. Neurotoxicology 26(2), 199-209.

Zhang, J., R. Stewart, M. Phillips, Q. Shi, and M. Prince: 2009, 'Pesticide exposure and suicidal ideation in rural communities in Zhejiang province, China'. Bulletin of the World Health Organization 87(10), 745-753.

Zhao, B., H. Shen, F. Liu, S. Liu, J. Niu, F. Guo, and X. Sun: 2011, 'Exposure to organochlorine pesticides is an independent risk factor of hepatocellular carcinoma: A case-control study'. Journal of Exposure Science and Environmental Epidemiology 22(6), 541-548.

Zheng, T., S. H. Zahm, K. P. Cantor, D. D. Weisenburger, Y. Zhang, and A. Blair: 2001, 'Agricultural exposure to carbamate pesticides and risk of non-Hodgkin lymphoma'. Journal of Occupational and Environmental Medicine 43(7), 641-649.

Zhu, J. L., N. H. Hjollund, A. M. N. Andersen, and J. Olsen: 2006, 'Occupational exposure to pesticides and pregnancy outcomes in gardeners and farmers: a study within the Danish National Birth Cohort'. Journal of Occupational and Environmental Medicine 48(4), 347-352. 
Zilberman, D. and K. Millock: 1997, 'Pesticide use and regulation: Making economic sense out of an externality and regulation nightmare'. Journal of Agricultural and Resource Economics 22, 321-32. 
Appendix 
Table 1: Direct exposure

\begin{tabular}{|c|c|c|c|}
\hline Reference & Main conclusions & Data & Quantitative Results \\
\hline \multicolumn{4}{|c|}{ CANCER } \\
\hline $\begin{array}{l}\text { Alavanja et al. } \\
\quad(2003)\end{array}$ & $\begin{array}{l}\text { Significant prostate cancer risk associated to pesticide exposure. } \\
\text { Interaction of family history with pesticide exposure is observed. }\end{array}$ & $\begin{array}{l}\text { Agricultural Health Study: } 55,332 \text { male } \\
\text { pesticide applicators from lowa and } \\
\text { North Carolina. }\end{array}$ & $\begin{array}{l}\text { Prostate cancer standardized incidence ratio of } 1.14(95 \% \mathrm{Cl} \text { : } \\
1.05-1.24) .\end{array}$ \\
\hline $\begin{array}{l}\text { Alavanja et al. } \\
\qquad(2004)\end{array}$ & $\begin{array}{l}\text { Non-significant lung cancer risk is associated to pesticide } \\
\text { exposure in general (due in large part to low cigarette smoking } \\
\text { prevalence). Two herbicides (metolachlor and pendimethalin) and } \\
\text { two insecticides (chlorpyrifos and diazinon) show significant } \\
\text { exposure response for lung cancer. }\end{array}$ & $\begin{array}{l}\text { Agricultural Health Study: } 57,284 \text { male } \\
\text { pesticide applicators and } 32,333 \\
\text { spouses of applicators from lowa and } \\
\text { North Carolina. }\end{array}$ & $\begin{array}{c}\text { Lung cancer standardized incidence ratio of } 0.44(95 \% \mathrm{Cl}: 0.39- \\
\text { 0.49). Significant exposure-response trends: } \\
\text { Metolachlor } P(\text { trend })=0.0002 \\
\text { Pendimethalin: } P(\text { (trend })=0.003 \\
\text { Chlorpyrifos: } P(\text { trend })=0.03 \\
\text { Diazinon: } P(\text { trend })=0.04\end{array}$ \\
\hline $\begin{array}{l}\text { Andreotti et al. } \\
\qquad(2009)\end{array}$ & $\begin{array}{l}\text { Organochlorines are not associated with an excess risk of } \\
\text { pancreatic cancer, while herbicides might be associated with it. }\end{array}$ & $\begin{array}{l}\text { Agricultural Health Study: } 93 \text { incident } \\
\text { cases, and } 82,503 \text { cancer-free controls. }\end{array}$ & $\begin{array}{l}\text { Significant odd ratios for: } \\
\text { Pendimethalin: } 3.00 \text { (95\%Cl: } 1.3-7.2) \\
\text { EPTC: } 2.56 \text { (95\%Cl: } 1.1-5.4)\end{array}$ \\
\hline $\begin{array}{l}\text { Andreotti et al. } \\
\quad(2010)\end{array}$ & $\begin{array}{l}\text { Obesity and pesticide use are associated with increased risk of } \\
\text { cancer. The results suggest that certain pesticides may modify the } \\
\text { effects of obesity on the risks of colon and lung cancer. }\end{array}$ & $\begin{array}{l}\text { Agricultural Health Study: } 39,628 \text { men } \\
\text { and 28,319 women from lowa and North } \\
\text { Carolina. }\end{array}$ & $\begin{array}{l}\text { Hazard ratios: BMI (body mass index) and colon cancer: } 1.05 \text {; } \\
\text { BMI and lung cancer: 0.92; BMI and colon cancer for users of } \\
\text { carbofuran:1.10; BMI and lung cancer for users of carbofuran: } \\
1.01 \text { (not significant) }\end{array}$ \\
\hline Baris et al. (2004) & $\begin{array}{l}\text { There is a modest increase in risk of multiple myeloma due to } \\
\text { pesticide exposure. Certain animal viruses may be involved in the } \\
\text { increasing risk. }\end{array}$ & $\begin{array}{l}\text { Data collected: } 573 \text { myeloma cases and } \\
2131 \text { control cases, and a job-exposure } \\
\text { matrix developed to calculate the } \\
\text { exposure levels. }\end{array}$ & $\begin{array}{l}\text { Significant odds ratios for sheep farm workers (1.7), pharmacists, } \\
\text { dieticians and therapists (6.1), service occupations (1.3), but not } \\
\text { for farmers. }\end{array}$ \\
\hline Barry et al. (2012) & $\begin{array}{l}\text { The findings suggest a significant role of the nucleotide excision } \\
\text { repair in the increased risk of prostate cancer risk due to pesticide } \\
\text { exposure. }\end{array}$ & $\begin{array}{l}\text { Agricultural Health Study: } 776 \text { prostate } \\
\text { cancer cases and } 1444 \text { male controls. } \\
\text { Focus on white pesticide applicators. }\end{array}$ & $\begin{array}{l}\text { Significant odds ratio for prostate cancer risk with high fonofos } \\
\text { use (2.98), and high carbofuran use (2.01) for specific nucleotide } \\
\text { excision repairs. }\end{array}$ \\
\hline $\begin{array}{l}\text { Beane et al. } \\
\quad(2005)\end{array}$ & $\begin{array}{l}\text { Routine application of diazinon (using lifetime exposure days) } \\
\text { shows increased risks with significant tests for trend for lung } \\
\text { cancer and leukemia. }\end{array}$ & $\begin{array}{l}\text { Agricultural Health Study: } 23,106 \text { male } \\
\text { applicators in lowa and North Carolina. }\end{array}$ & $\begin{array}{l}\text { Rate ratios: } \\
\text { Lung Cancer: } 2.41 \text { (95\% Cl: } 1.31-4.43) \\
\text { Leukemia: } 3.36 \text { ( } 95 \% \mathrm{Cl}: 1.08-10.49)\end{array}$ \\
\hline $\begin{array}{l}\text { Beane et al. } \\
\quad(2011)\end{array}$ & $\begin{array}{l}\text { No consistent evidence to associate atrazine use and any cancer. } \\
\text { For some cancers, results are based on relatively small numbers, } \\
\text { which reduces the robustness of the results. }\end{array}$ & $\begin{array}{l}\text { Agricultural Health Study: } 57,310 \\
\text { pesticide applicators; from which } 36,357 \\
\text { users of atrazine, with } 3,146 \text { cancer } \\
\text { cases (in lowa and North Carolina). }\end{array}$ & $\begin{array}{l}\text { 95\% Cl of Relative Risks (RRs) for all type of cancers, by } \\
\text { pesticide exposure quartiles: } \\
\text { Q1 (reference); Q2: [0.93-1.13]; } \\
\text { Q3: }[0.90-1.10] ; \text { Q4 [0.96-1.18]. }\end{array}$ \\
\hline Datta et al. (2006) & $\begin{array}{l}\text { The use of organic arsenicals as pesticides in mineral soils may } \\
\text { not be a safe practice from a human health risk perspective. }\end{array}$ & $\begin{array}{l}\text { Static incubation study to estimate soil } \\
\text { speciation and in-vitro bioavailability of } \\
\text { arsenic as a function of soil properties. }\end{array}$ & $\begin{array}{c}\text { Excess Cancer Risk (ECR) with Tobosa soil (after } 12 \text { months } \\
\text { using bioavailability values) } \\
\text { Concentration of } 45: 0.23 \mathrm{ECR} \\
\text { Concentration of 225: } 1.59 \mathrm{ECR} \\
\text { Concentration of } 450: 3.78 \mathrm{ECR}\end{array}$ \\
\hline $\begin{array}{l}\text { De Brito et al. } \\
\text { (2005) }\end{array}$ & $\begin{array}{l}\text { There is an almost two times higher probability of cancer } \\
\text { development among rural workers, with a significant relative risk } \\
\text { for agriculture workers. }\end{array}$ & $\begin{array}{l}\text { Data collected: } 68 \text { cancer cases and } 60 \\
\text { controls, obtained from the Amaral } \\
\text { Carvalho Hospital, at the city of Jau } \\
\text { from } 2000 \text { to } 2002 \text {. }\end{array}$ & $\begin{array}{l}\text { Relative risk ratio for agriculture workers (versus other } \\
\text { occupations) of } 1.6 \text { ( } \mathrm{Cl} \text { are not reported). }\end{array}$ \\
\hline
\end{tabular}




\begin{tabular}{|c|c|c|c|}
\hline Reference & Main conclusions & Data & Quantitative Results \\
\hline $\begin{array}{l}\text { De Roos et al. } \\
\text { (2005) }\end{array}$ & $\begin{array}{l}\text { Glyphosate exposure is not associated with cancer incidence } \\
\text { overall or with most of the cancer subtypes studied. }\end{array}$ & $\begin{array}{l}\text { Agricultural Health Study: } 57,311 \\
\text { licensed pesticide applicators in lowa } \\
\text { and North Carolina. }\end{array}$ & $\begin{array}{l}\text { Rate ratios adjusted for age: } \\
\text { All cancers: } 1.0(95 \% \mathrm{Cl}: 0.9-1.1) \\
\text { Melanoma: } 1.8(95 \% \mathrm{Cl}: 1.0-3.4)\end{array}$ \\
\hline $\begin{array}{l}\text { Dennis et al. } \\
\quad(2010)\end{array}$ & $\begin{array}{l}\text { There is an association between several pesticides and } \\
\text { melanoma, which provides support for considering agricultural } \\
\text { chemicals as another source of melanoma risk. }\end{array}$ & $\begin{array}{l}\text { Agricultural Health Study: } 52,394 \text { private } \\
\text { pesticide applicators, } 4,916 \text { licensed } \\
\text { commercial applicators, and } 32,347 \\
\text { spouses of applicators in lowa and } \\
\text { North Carolina. }\end{array}$ & $\begin{array}{c}\text { 95\% Cl of odds ratios: } \\
\text { Maneb (>63days): } 1.2-4.9 \\
\text { Parathion (>56days): } 1.3-4.4 \\
\text { Carbaryl (>56days): } 1.1-2.5\end{array}$ \\
\hline $\begin{array}{l}\text { Greenburg et al. } \\
\quad(2008)\end{array}$ & $\begin{array}{l}\text { The results of this study do not provide evidence of an increased } \\
\text { risk for the development of cancer due to captan exposure }\end{array}$ & $\begin{array}{l}\text { Agricultural Health Study: } 48,986 \text { private } \\
\text { and commercial pesticide applicators in } \\
\text { lowa and North Carolina. }\end{array}$ & $\begin{array}{l}\text { No significant rate ratios between highest tertile of captan } \\
\text { exposure and development of all cancers: } \\
\text { RR }=0.89(95 \% \text { Cl: } 0.71-1.13)\end{array}$ \\
\hline $\begin{array}{l}\text { Hardell et al. } \\
\quad(2002)\end{array}$ & $\begin{array}{l}\text { Increased risk of non-Hodgkin lymphoma and hairy cell leukemia } \\
\text { are found following an univariate analysis associated with } \\
\text { exposure to herbicides, insecticides, fungicides, and impregnating } \\
\text { agents. }\end{array}$ & $\begin{array}{l}\text { Data collected by questionnaires: } \\
\text { pooled analysis with } 515 \text { cases and } \\
1141 \text { controls. }\end{array}$ & $\begin{array}{l}\text { Significant odds ratios for: herbicides (1.75), insecticides (1.43), } \\
\text { fungicides (3.11), impregnating agents (1.48). }\end{array}$ \\
\hline Hou et al. (2004) & $\begin{array}{l}\text { Results suggest an association between pendimethalin exposure } \\
\text { and incidence of rectum and lung cancer. }\end{array}$ & $\begin{array}{l}\text { Agricultural Health Study: } 9,089 \\
\text { pendimethalin-exposed cases and } \\
26,836 \text { controls, enrolled between } 1993 \\
\text { and } 1997 .\end{array}$ & $\begin{array}{l}\text { Significant increased RRs for pendimethalin-exposed cases of: } \\
3.5 \text { (for rectum cancer); } 5.2 \text { (for lung cancer and upper half of } \\
\text { highest tertile exposure days). }\end{array}$ \\
\hline $\begin{array}{l}\text { Hughes et al. } \\
\qquad(2011)\end{array}$ & $\begin{array}{l}\text { Significant association between prostate cancer and fonofos } \\
\text { exposure on men with family history of prostate cancer, suggesting } \\
\text { a role of BER genetic variation in pesticide-associated prostate } \\
\text { cancer risk. }\end{array}$ & $\begin{array}{l}\text { Agricultural Health Study: } 776 \text { prostate } \\
\text { cancer cases, and } 1,444 \text { controls (in } \\
\text { lowa and North Carolina). }\end{array}$ & $\begin{array}{l}95 \% \text { Cl of odds ratios of prostate cancer risk and: } \\
\text { rs1983132 (low use): } 0.91-3.01 \\
\text { rs1983132 (high use): } 1.78-5.92\end{array}$ \\
\hline Kang et al. (2008) & $\begin{array}{l}\text { Trifluralin exposure is not associated with cancer incidence overall } \\
\text { however, there is an excess of colon cancer in the exposure } \\
\text { category of higher half of highest tertile (might be a chance finding) }\end{array}$ & $\begin{array}{l}\text { Agricultural Health Study: } 50,127 \text { private } \\
\text { and commercial pesticide applicators in } \\
\text { lowa and North Carolina. }\end{array}$ & $\begin{array}{l}\text { Rate ratios (referent }=\text { non-exposed): } \\
\text { All cancers: } 0.99(95 \% \mathrm{Cl}: 0.83-1.17) \\
\text { Colon cancer: } 1.76 \text { (95\% Cl: } 1.05-2.95)\end{array}$ \\
\hline $\begin{array}{l}\text { Karunanayake et } \\
\quad \text { al. (2012) }\end{array}$ & $\begin{array}{l}\text { Results suggest an increased risk of Hodgkin lymphoma } \\
\text { associated with specific pesticides. }\end{array}$ & $\begin{array}{l}\text { Data collected: Mailed questionnaire } \\
\text { followed by a telephone interview with } \\
316 \text { Hodgkin lymphoma cases and } 1506 \\
\text { controls in } 6 \text { regions of Canada }\end{array}$ & $\begin{array}{l}\text { Increased risk for Hodgkin lymphoma associated to exposure to } \\
\text { insecticide chlorpyrifos ( } 1.19,95 \% \text { Cl: } 1.03,1.37) \text {, and other } \\
\text { factors, such as family history of cancer and previous diagnosis } \\
\text { of shingles. }\end{array}$ \\
\hline $\begin{array}{l}\text { Kokouva et al. } \\
\quad(2011)\end{array}$ & $\begin{array}{l}\text { Lymphohaematopoietic cancers (LHC) are associated with } \\
\text { pesticide exposures. Smoking or eating during pesticide } \\
\text { application are modifying factors that increase the risk. }\end{array}$ & $\begin{array}{l}\text { Data collected: } 354 \text { confirmed LHC } \\
\text { cases (diagnosed from } 2004 \text { to 2006) } \\
\text { and } 455 \text { controls, located at Larissa, } \\
\text { Greece. }\end{array}$ & $\begin{array}{l}\text { Significant odds ratios of pesticide exposure for: total LHC cases } \\
\text { (1.46), myelodysplastic syndrome (1.87), and leukaemia (2.14). }\end{array}$ \\
\hline $\begin{array}{l}\text { Koutros et al. } \\
(2009)\end{array}$ & $\begin{array}{l}\text { Significant trends in risk with increasing lifetime exposure to } \\
\text { imazethapyr are found for bladder cancer and colon cancer. }\end{array}$ & $\begin{array}{l}\text { Agricultural Health Study: } 49,398 \\
\text { licensed pesticide applicators in the US. }\end{array}$ & $\begin{array}{l}\text { Rate ratios: } \\
\text { Bladder Cancer: } 2.37 \text { (95\% Cl: } 1.20-4.68) \\
\text { Colon Cancer: } 1.78 \text { ( } 95 \% \mathrm{Cl}: 1.08-2.93)\end{array}$ \\
\hline & & & Continue on next page \\
\hline
\end{tabular}




\begin{tabular}{|c|c|c|c|}
\hline Reference & Main conclusions & Data & Quantitative Results \\
\hline Lee et al. (2004) & $\begin{array}{l}\text { There exists an association between alachlor application and } \\
\text { incidence of lymphohematopoietic cancers. }\end{array}$ & $\begin{array}{l}\text { Agricultural Health Study: } 49,980 \\
\text { pesticide applicators in lowa and North } \\
\text { Carolina. }\end{array}$ & $\begin{array}{l}\text { Rate ratios (using intensity-weighted exposure-days): } \\
\text { All lymphohematopoietic cancers: } 2.42 \text { (95\% Cl: 1.0-5.89) } \\
\qquad \begin{array}{l}\text { P(trend) }=0.03\end{array}\end{array}$ \\
\hline Lee et al. (2004a) & $\begin{array}{l}\text { The results suggest an association between chlorpyrifos use and } \\
\text { incidence of lung cancer. }\end{array}$ & $\begin{array}{l}\text { Agricultural Health Study: } 54,383 \\
\text { pesticide applicators in lowa and North } \\
\text { Carolina. }\end{array}$ & $\begin{array}{c}\text { Rate ratios (adjusting for other pesticide exposures and } \\
\text { demographic factors): } \\
\text { Lung cancer: } 2.18 \text { ( } 95 \% \mathrm{Cl}: 1.31-3.64)\end{array}$ \\
\hline Lee et al. (2006) & $\begin{array}{l}\text { No significant association is found between pesticide exposures } \\
\text { and mortality of lung cancer in the population of Leningrad }\end{array}$ & $\begin{array}{l}\text { Data collected: } 540 \text { lung cancer cases } \\
\text { and } 582 \text { controls obtained from the } \\
\text { registers of people dying in the hospitals } \\
\text { of Leningrad between } 1993 \text { and } 1998 .\end{array}$ & $\begin{array}{l}\text { No significant odds ratios between pesticide exposure and lung } \\
\text { cancer mortality: } 1.06 \text { ( } 95 \% \text { Cl: } 0.82-1.36) \text {. }\end{array}$ \\
\hline Lee et al. (2007b) & $\begin{array}{c}\text { There exists an association between exposure to certain } \\
\text { pesticides and incidence of colorectal cancer among pesticide } \\
\text { applicators. }\end{array}$ & $\begin{array}{l}\text { Agricultural Health Study: } 56,813 \\
\text { pesticide applicators in lowa and North } \\
\text { Carolina. }\end{array}$ & $\begin{array}{l}\text { Odds ratios: } \\
\text { Chlorpyrifos for rectal cancer: } 2.7(95 \% \mathrm{Cl}: 1.2-6.4) \\
\text { Aldicarb with colon cancer: } 4.1 \text { (95\% Cl:1.3-12.8) }\end{array}$ \\
\hline Lynch et al. (2006) & $\begin{array}{l}\text { There is no clear and consistent association between cyanazine } \\
\text { exposure and any of the cancer analyzed. }\end{array}$ & $\begin{array}{l}\text { Agricultural Health Study: } 57,311 \\
\text { pesticide applicators in lowa and North } \\
\text { Carolina. }\end{array}$ & $\begin{array}{c}\text { 95\% Cl of the Rate ratios: } \\
\text { All cancers: } 0.80-1.24 \\
\text { Prostate cancer: } 0.87-1.70 \\
\text { All lymphohematopoietic cancers: } 0.50-1.72\end{array}$ \\
\hline Lynch et al. (2009) & $\begin{array}{l}\text { Statistically significant increased risks and exposure-response } \\
\text { trends are observed for all lymphohematopoietic cancers and non- } \\
\text { Hodgkin lymphoma, as well as increased risk for prostate cancer. }\end{array}$ & $\begin{array}{l}\text { Agricultural Health Study: } 19,655 \\
\text { pesticide applicators in lowa and North } \\
\text { Carolina. }\end{array}$ & $\begin{array}{l}\text { 95\% Cl of the Rate ratios: } \\
\text { Prostate cancer: } 1.27-3.44 \\
\text { NHL cancer: } 1.29-9.21 \\
\text { All lymphohematopoietic cancers: } 1.18-4.37\end{array}$ \\
\hline $\begin{array}{l}\text { Mathur et al. } \\
\quad(2002)\end{array}$ & $\begin{array}{l}\text { Organochlorine pesticides taken for analysis are found significantly } \\
\text { high in breast cancer patients irrespective of age, diet, and } \\
\text { geographic distribution. }\end{array}$ & $\begin{array}{l}\text { Data collected: } 135 \text { breast cancer } \\
\text { patients and } 50 \text { female controls from the } \\
\text { Birla Cancer Institute (Jaipur). }\end{array}$ & $\begin{array}{l}\text { Organochlorine pesticide residues(DDT) in the blood of: controls: } \\
1.034(0.221) \text {; } \\
\text { with breast cancer: } 2.254(0.405)\end{array}$ \\
\hline $\begin{array}{l}\text { McDuffie et al. } \\
\quad(2001)\end{array}$ & $\begin{array}{l}\text { Non-Hodgkin Lymphoma is associated with specific pesticides } \\
\text { after adjustment for other independent predictors. }\end{array}$ & $\begin{array}{l}\text { Canadian multicenter population-based } \\
\text { incident, case }(n=517) \text { - control } \\
\qquad(n=1506) \text { study. }\end{array}$ & $\begin{array}{c}95 \% \mathrm{Cl} \text { of odd ratios for different pesticides: } \\
\text { Phenoxyherbicides: }(1.06,1.81) ; \text { Dicamba (1.32,2.68); Carbamate } \\
\text { (1.22,3.04); Organophosphorus (1.27,2.36); Fumigant carbon } \\
\text { tetrachloride }(1.19,5.14)\end{array}$ \\
\hline $\begin{array}{l}\text { Mozzachio et al. } \\
\text { (2008) }\end{array}$ & $\begin{array}{l}\text { No strong evidence for an association between chlorothalonil and } \\
\text { the cancers investigated is found. }\end{array}$ & $\begin{array}{l}\text { Agricultural Health Study: } 47,625 \\
\text { pesticide applicators in lowa and North } \\
\text { Carolina. }\end{array}$ & $\begin{array}{l}95 \% \mathrm{Cl} \text { of the Rate ratios: All cancers: } 0.83-1.32 \text {; Colon cancer: } \\
0.70 \text { - 3.03; Lung cancer: } 0.51-1.83 \text {; Prostate cancer: } 0.52- \\
1.21\end{array}$ \\
\hline $\begin{array}{l}\text { Pahwa et al. } \\
\text { (2011) }\end{array}$ & $\begin{array}{l}\text { Soft-tissue sarcoma is associated only with specific pesticides } \\
\text { (Aldrin and Diazinon). }\end{array}$ & $\begin{array}{l}\text { Data collected: Mailed questionnaire } \\
\text { followed by a telephone interview with } \\
357 \text { multiple myeloma cases and } 1506 \\
\text { controls in } 6 \text { regions of Canada }\end{array}$ & $\begin{array}{l}\text { Significant odds ratios of soft-tissue sarcoma for exposure to } \\
\text { different pesticides: Aldrin (3.71,95\% Cl: } 1.00,13.76) \text {; Diazinon } \\
\text { (3.31, } 95 \% \text { Cl: } 1.78,6.23)\end{array}$ \\
\hline $\begin{array}{l}\text { Pahwa et al. } \\
\text { (2012) }\end{array}$ & $\begin{array}{l}\text { Increased risk of multiple myeloma is associated to the exposure } \\
\text { to carbamate pesticides, and fungicide captan. }\end{array}$ & $\begin{array}{l}\text { Data collected: Mailed questionnaire } \\
\text { followed by a telephone interview with } \\
342 \text { multiple myeloma cases and } 1506 \\
\text { controls in } 6 \text { regions of Canada }\end{array}$ & $\begin{array}{l}\text { Significant odds ratios for multiple myeloma associated to } \\
\text { exposure to carbamates (1.90) and fungicide captan (2.35). }\end{array}$ \\
\hline Potti et al. (2003) & $\begin{array}{l}\text { There is evidence associating pesticide exposure to the early } \\
\text { development of prostate adenocarcinoma, potentially aggressive. }\end{array}$ & $\begin{array}{l}\text { Data collected: } 56 \text { young males with } \\
\text { adenocarcinoma diagnosed between } \\
1991 \text { and } 2001 \text {, with complete records } \\
\text { in North Dakota and Western } \\
\text { Minnesota. }\end{array}$ & $\begin{array}{l}\text { From the subjects with adenocarcinoma, } 66.1 \% \text { have significant } \\
\text { exposure to pesticides. The mean survival of the subgroup with } \\
\text { pesticide exposure is } 11.3 \text { months, while for those without } \\
\text { exposure is } 20.1 \text { months. }\end{array}$ \\
\hline & & & Continue on next page \\
\hline
\end{tabular}




\begin{tabular}{|c|c|c|c|}
\hline Reference & Main conclusions & Data & Quantitative Results \\
\hline $\begin{array}{l}\text { Ruder et al. } \\
\quad(2004)\end{array}$ & $\begin{array}{l}\text { No positive association of farm pesticide exposure and glioma is } \\
\text { found in this study. }\end{array}$ & $\begin{array}{l}\text { Data collected: } 457 \text { glioma cases and } \\
648 \text { controls. Adult men residents of } \\
\text { lowa, Michigan, Minnesota, and } \\
\text { Wisconsin. } \\
\end{array}$ & $\begin{array}{l}\text { No significant odds ratios for: insecticides }(0.53) \text {, fumigants } \\
(0.57) \text {, and organochlorines }(0.66) \text {. }\end{array}$ \\
\hline $\begin{array}{l}\text { Rusiecki et al. } \\
\quad(2004)\end{array}$ & $\begin{array}{l}\text { The analysis does not find any clear association between atrazine } \\
\text { exposure and any cancer analyzed. }\end{array}$ & $\begin{array}{l}\text { Agricultural Health Study: } 53,943 \\
\text { pesticide applicators in lowa and North } \\
\text { Carolina. }\end{array}$ & $\begin{array}{c}95 \% \mathrm{Cl} \text { of the Rate ratios for different cancers: } \\
\text { Prostate: }(0.63,1.23) \text {; Lung }(0.93,3.94) ; \text { Bladder }(0.86,10.81) \text {; } \\
\text { NHL }(0.62,4.16) ; \text { Multiple myeloma }(0.37,7.01)\end{array}$ \\
\hline $\begin{array}{l}\text { Rusiecki et al. } \\
\quad(2006)\end{array}$ & $\begin{array}{c}\text { The analysis does not detect strong evidence for an association } \\
\text { between metolachlor exposure and any of the cancer sites } \\
\text { investigated. Future research should put special attention to } \\
\text { prostate and lung cancer. }\end{array}$ & $\begin{array}{l}\text { Agricultural Health Study: 50,193 } \\
\text { pesticide applicators in lowa and North } \\
\text { Carolina. }\end{array}$ & $\begin{array}{l}\text { Rate ratios for exposure to metolachlor: } \\
\text { Highest-exposure for prostate cancer: } 0.59 \\
\text { 2nd-highest-exposure for prostate cancer: } 0.66\end{array}$ \\
\hline $\begin{array}{l}\text { Rusiecki et al. } \\
\quad(2009)\end{array}$ & $\begin{array}{l}\text { The study finds no association between permethrin and most } \\
\text { cancers analyzed. For multiple myeloma this result is based on } \\
\text { small numbers. }\end{array}$ & $\begin{array}{l}\text { Agricultural Health Study: } 49,093 \\
\text { pesticide applicators in lowa and North } \\
\text { Carolina. }\end{array}$ & $\begin{array}{c}95 \% \mathrm{Cl} \text { of the Rate ratios for different cancers: } \\
\text { Prostate: }(0.64,1.18) ; \text { Lung }(0.35,1.34) ; \text { Bladder }(0.64,2.74) ; \mathrm{NHL} \\
\text { (0.28,1.71); Multiple myeloma (2.76,11.87); Leukemia } \\
(0.83,3.64) ; \text { Melanoma }(0.35,1.83) .\end{array}$ \\
\hline $\begin{array}{l}\text { Samanic et al. } \\
\quad(2006)\end{array}$ & $\begin{array}{l}\text { No clear evidence is found for an association between dicamba } \\
\text { exposure and cancer risk. However, the relation with lung and } \\
\text { colon cancer should be further studied. }\end{array}$ & $\begin{array}{l}\text { Agricultural Health Study: } 41,969 \\
\text { pesticide applicators in lowa and North } \\
\text { Carolina. }\end{array}$ & $\begin{array}{l}95 \% \mathrm{Cl} \text { of the Rate ratios for different cancers: } \\
\text { All cancers: }(0.85,1.23) \text {; Colon: }(0.78,2.58) ; \text { Prostate: }(0.81,1.46) \text {; } \\
\text { Lung }(0.79,2.72) ; \text { Bladder }(0.36,1.88) ; \mathrm{NHL}(0.50,2.85) ; \text { All } \\
\text { hematopoietic: }(0.74,2.31) \text {; Melanoma }(0.33,2.13)\end{array}$ \\
\hline $\begin{array}{l}\text { Samanic et al. } \\
\quad(2008)\end{array}$ & $\begin{array}{l}\text { Increased risk of meningioma and herbicide exposure is significant } \\
\text { for women, but no association is found for men. }\end{array}$ & $\begin{array}{l}\text { Data collected in the U.S.: } 462 \text { glioma } \\
\text { cases, } 195 \text { meningioma cases } \\
\text { (diagnosed between } 1994 \text { and 1998), } \\
\text { and } 765 \text { controls. }\end{array}$ & $\begin{array}{l}\text { Significant odds ratio for women using herbicides }(2.4,95 \% \mathrm{Cl} \text { : } \\
\text { 1.4,4.3), with a significant trend with increasing years of } \\
\text { exposure. }\end{array}$ \\
\hline $\begin{array}{l}\text { Van Bemmel et al. } \\
\qquad(2008)\end{array}$ & $\begin{array}{l}\text { S-ethyl-N,N-dipropylthiocarbamate (EPTC) use is associated with } \\
\text { colon cancer and leukemia. Due to small numbers results should } \\
\text { be interpreted with caution and further investigations are needed. }\end{array}$ & $\begin{array}{l}\text { Agricultural Health Study: } 48,378 \\
\text { pesticide applicators in lowa and North } \\
\text { Carolina. }\end{array}$ & $\begin{array}{l}95 \% \mathrm{Cl} \text { of the Rate ratios and } \mathrm{p} \text {-trend: } \\
\text { Colon cancer: } 1.26-3.47(\mathrm{p} \text {-trend }=<0.01) \\
\text { Leukemia: } 1.16-4.84(p \text {-trend }=0.02)\end{array}$ \\
\hline $\begin{array}{l}\text { Weichenthal et al. } \\
\qquad(2010)\end{array}$ & $\begin{array}{l}\text { Review of cancer studies related to pesticide use in the AHS. } \\
\text { Most of the } 32 \text { pesticides examined are not strongly associated } \\
\text { with cancer incidence. }\end{array}$ & $\begin{array}{l}28 \text { studies that examined the } \\
\text { relationship between pesticide } \\
\text { exposures and cancer incidence in the } \\
\text { AHS cohort. }\end{array}$ & $\begin{array}{l}\text { In Table } 1 \text { the authors resume all the pesticides with significant } \\
\text { association with cancer being analyzed using the AHS. }\end{array}$ \\
\hline Xu et al. (2010) & $\begin{array}{l}\text { The results suggest that } \mathrm{OC} \text { pesticide use is related with an } \\
\text { increase on cancer risk. }\end{array}$ & $\begin{array}{c}\text { National Health and Nutrition } \\
\text { Examination Survey (1999-2004). From } \\
1,475 \text { to } 1,693 \text { participants, depending } \\
\text { on the year. }\end{array}$ & $\begin{array}{l}\text { Adjusted odd ratios for second and third tertiles: beta-HCH: } 1.46 \\
\text { and } 3.36 \text {; trans-nonachlor: } 5.84 \text { and } 14.1 \text {; dieldrin: } 1.06 \text { and } 2.74 \text {. }\end{array}$ \\
\hline Zhao et al. (2011) & $\begin{array}{l}\text { High-level organochlorine pesticide exposure combined with } \\
\text { aflatoxin B1 and Hepatitis B virus may greatly enhance the risk of } \\
\text { Hepatocellular carcinoma. }\end{array}$ & $\begin{array}{c}\text { Data collected: Questionnaire database } \\
\text { built from } 346 \text { Hepatocellular carcinoma } \\
\text { cases, and } 961 \text { controls in Xiamen } \\
\text { (2007-09). }\end{array}$ & $\begin{array}{l}\text { Positive interactions of DDT pesticide residues with HBV, } \\
\text { diabetes mellitus, aflatoxin B1. }\end{array}$ \\
\hline $\begin{array}{l}\text { Zheng et al. } \\
\quad(2001)\end{array}$ & $\begin{array}{l}\text { The results suggest an increased risk of non-Hodgkin lymphoma } \\
\text { associated with carbamate pesticide exposure. }\end{array}$ & $\begin{array}{l}\text { Three population-based case-control } \\
\text { studies: } 985 \text { white male subjects and } \\
2895 \text { controls, from four Midwestern } \\
\text { states in the U.S. }\end{array}$ & $\begin{array}{l}\text { Significant odds ratios of NHL associated with Carbamate } \\
\text { pesticide use: } 1.5(95 \% \mathrm{Cl}: 1.1-2.0)\end{array}$ \\
\hline \multicolumn{4}{|c|}{ DEPRESSION \& NEUROLOGICAL DEFICITS } \\
\hline Abdel et al. (2008) & $\begin{array}{l}\text { Functional cognitive deficits are associated with increased years of } \\
\text { exposure to organophosphate pesticides. }\end{array}$ & $\begin{array}{l}\text { Data collected: } 50 \text { male children } \\
\text { applying pesticides, and } 50 \text { controls } \\
\text { were recruited in Egypt. }\end{array}$ & $\begin{array}{c}\text { Pesticide applicators performed significantly worse in } 10 \text { tasks } \\
\text { (out of 10) measuring neurobehavioral performance ( } p \text {-value < } \\
0.04) \text {. }\end{array}$ \\
\hline & & & Continue on the next page \\
\hline
\end{tabular}




\begin{tabular}{|c|c|c|c|}
\hline Reference & Main conclusions & Data & Quantitative Results \\
\hline Baldi et al. (2001) & $\begin{array}{l}\text { Low-level exposure to pesticides in occupational conditions has an } \\
\text { effect on long-term cognitive performance. }\end{array}$ & $\begin{array}{l}\text { Data collected: } 917 \text { Bordeaux vineyard } \\
\text { workers (528 directly exposed to } \\
\text { pesticides; } 173 \text { indirectly exposed; } 216 \\
\text { never exposed). }\end{array}$ & $\begin{array}{l}\text { Workers with direct exposure: significant lower performance } \\
\text { (than no exposed workers) in } 6 \text { out of } 9 \text { tests. Workers with } \\
\text { indirect exposure: significant lower performance (than no } \\
\text { exposed) in } 5 \text { out of } 9 \text { tests. }\end{array}$ \\
\hline $\begin{array}{l}\text { Beseler et al. } \\
\quad(2008)\end{array}$ & $\begin{array}{l}\text { Both acute high-intensity and cumulative pesticide exposure may } \\
\text { contribute to depression in pesticide applicators. Depression is } \\
\text { also associated with chronic pesticide exposure in the absence of } \\
\text { a physician-diagnosed poisoning. }\end{array}$ & $\begin{array}{l}\text { Agricultural Health Study: } 534 \text { cases } \\
\text { and } 17,051 \text { controls among private } \\
\text { pesticide applicators in lowa and North } \\
\text { Carolina. }\end{array}$ & $\begin{array}{c}95 \% \mathrm{Cl} \text { of the Odds ratios: Pesticide poisoning: } 1.74-3.79 \\
\text { Intermediate cumulative exposure: } 0.87-1.31 ; \text { High cumulative } \\
\text { exposure: } 0.87-1.42 ; \mathrm{HPEE}: 1.33-2.05 ; \text { High cumulative } \\
\text { exposure among applicators without history of acute poisoning: } \\
1.16-2.04\end{array}$ \\
\hline $\begin{array}{l}\text { Bosma et al. } \\
\quad(2000)\end{array}$ & $\begin{array}{l}\text { Exposure to pesticides by arable farmers and gardeners is } \\
\text { associated with increased risks of mild cognitive dysfunction } \\
\text { (MCD). }\end{array}$ & $\begin{array}{l}\text { Maastricht Aging Study: } 830 \text { individuals } \\
\text { included with 3-year follow-up } \\
\text { examination (1996-98) }\end{array}$ & $\begin{array}{l}\text { Significant increase in risk for } M C D \text { due to pesticide exposure: for } \\
\text { self-reported exposure (OR=4.94); for job-related exposure } \\
\text { (OR=1.47) (cross-sectional results). }\end{array}$ \\
\hline $\begin{array}{l}\text { Corder et al. } \\
\quad(2006)\end{array}$ & $\begin{array}{l}\text { Inherited variation in mitochondrial complex genes and pesticide } \\
\text { exposure together influence the risk for Parkinson's disease. }\end{array}$ & $\begin{array}{l}\text { Data collected: } 306 \text { cases and } 321 \\
\text { controls from an Australian case-control } \\
\text { sample. }\end{array}$ & $\begin{array}{l}\text { Groups with "early onset and regular exposure", and "early onset } \\
\text { and limited exposure" presented higher risk for Parkinson's } \\
\text { disease (OR: } 2.7 \text { and } 4.0) \text {. }\end{array}$ \\
\hline $\begin{array}{l}\text { Eckerman et al. } \\
\qquad(2007)\end{array}$ & $\begin{array}{l}\text { The effect of pesticide exposure on neurobehavioral performance } \\
\text { appeared to be especially strong for youngest population (10-11 } \\
\text { year old). }\end{array}$ & $\begin{array}{c}\text { Data collected: } 38 \text { farm children and } 28 \\
\text { children from a city, both in the state of } \\
\text { Rio de Janeiro, Brazil, and with ages } \\
\text { between } 10 \text { and } 18 \text { years. }\end{array}$ & $\begin{array}{l}\text { For } 10-11 \text { year old participants, } 5 \text { out of } 16 \text { behavioral measures } \\
\text { show a strong negative association, while for } 12-13 \text { year old } \\
\text { participants only } 1 \text {, and none for participants older than } 13 \text { year } \\
\text { old. }\end{array}$ \\
\hline Fong et al. (2007) & $\begin{array}{l}\text { Susceptible variants of MsSOD and NQO1 genes may have an } \\
\text { interaction with occupational pesticide exposure to increase the } \\
\text { risk of Parkinson's disease (PD). }\end{array}$ & $\begin{array}{l}\text { Data collected: } 153 \text { patients with } \\
\text { idiopathic PD and } 155 \text { healthy control } \\
\text { subjects from southwestern region of } \\
\text { Taiwan (2001-03). }\end{array}$ & $\begin{array}{l}\text { Risk of } P D \text { is associated with pesticide exposure: unadjusted } \\
O R=1.69 \text {; adjusted } O R=1.68 \text {. Polymorphisms of } M n S O D \text { and } \\
\text { NQO1 genes are associated to pesticide exposure ( } O R=2.49 \text { and } \\
\text { OR=2.42, respectively). }\end{array}$ \\
\hline $\begin{array}{l}\text { Hancock et al. } \\
\quad(2008)\end{array}$ & $\begin{array}{c}\text { Results show positive associations of pesticide exposure with } \\
\text { Parkinson's disease (PD). Frequency, duration, and cumulative } \\
\text { exposure are also significant factors. }\end{array}$ & $\begin{array}{l}\text { Data collected: } 319 \text { cases and } 296 \\
\text { controls, recruited from } 2000 \text { to } 2006 \text { at } \\
\text { the Duke University Medical Center. }\end{array}$ & $\begin{array}{l}\text { Significant increase in risk for PD for individuals applying: } \\
\text { herbicides (OR=1.59); pesticides other than herbicides } \\
\text { (OR=1.61); insecticides (OR=1.83). }\end{array}$ \\
\hline Hong et al. (2009) & $\begin{array}{l}\text { Evidence suggests that exposure to pesticide spraying is } \\
\text { associated with the development of depression in farmers. }\end{array}$ & $\begin{array}{l}\text { Data collected: } 82 \text { farmers living in the } \\
\text { Western region of South Korea }\end{array}$ & $\begin{array}{l}\text { The scores of depression tests are associated with the frequency } \\
\text { of spraying over a year ( } p<0.05) \text {, number of years farming } \\
(p<0.01) \text {, and history of intoxication }(p<0.01) \text {. }\end{array}$ \\
\hline $\begin{array}{l}\text { Kamel et al. } \\
\text { (2005) }\end{array}$ & $\begin{array}{l}\text { Results suggest that self-reported neurologic symptoms are } \\
\text { associated with cumulative exposure to moderate levels of } \\
\text { fumigants and organophosphate and organochlorine insecticides. }\end{array}$ & $\begin{array}{l}\text { Agricultural Health Study: } 18,782 \text { private } \\
\text { pesticide applicators in lowa and North } \\
\text { Carolina. }\end{array}$ & $\begin{array}{c}\text { Significant odd ratios for organophosphates (chlorines): } \\
\text { Insomnia: } 1.70(1.56) \text {; Depression: } 2.09 \text { (1.68); } \\
\text { Absentmindedness: } 2.13 \text { (1.75); Changes in smell or taste: } 1.83 \\
\text { (2.12); Difficulty speaking: } 1.94 \text { (1.97) }\end{array}$ \\
\hline $\begin{array}{l}\text { Kamel et al. } \\
\text { (2007) }\end{array}$ & $\begin{array}{l}\text { Incident Parkinson disease is associated with cumulative days of } \\
\text { pesticide use at enrollment. Exposure to certain pesticides may } \\
\text { increase Parkinson disease risk. }\end{array}$ & $\begin{array}{l}\text { Agricultural Health Study: } 83 \text { prevalent } \\
\text { cases, } 78 \text { incident cases, } 79,557 \\
\text { prevalent controls, and } 55,931 \text { incident } \\
\text { controls among pesticide applicators in } \\
\text { lowa and North Carolina. }\end{array}$ & $\begin{array}{c}\text { 95\% Cl of odds ratios: Incident Parkinson: } 1.2-4.5 ; \\
\text { Prevalent Parkinson: } 0.4-1.5\end{array}$ \\
\hline Lee et al. (2007) & $\begin{array}{l}\text { There is a possible association between chlorpyrifos use and } \\
\text { external causes of death. Although these results are based on } \\
\text { small numbers, may reflect a link between chlorpyrifos and } \\
\text { depression or other neurobehavioral symptoms. }\end{array}$ & $\begin{array}{l}\text { Agricultural Health Study: } 55,071 \\
\text { pesticide applicators in lowa and North } \\
\text { Carolina. }\end{array}$ & $\begin{array}{c}\text { 95\% Cl of Rate ratios related to lifetime chlorpyrifos exposure- } \\
\text { days: } \\
\text { Suicide: } 1.03-5.48 \\
\text { Non-motor-vehicle accidents: } 1.36-3.52\end{array}$ \\
\hline Park et al. (2012) & $\begin{array}{l}\text { No significant results, however the authors find some association } \\
\text { between occupational pesticide exposure and peripheral } \\
\text { neurophysiologic abnormality. }\end{array}$ & $\begin{array}{l}\text { Data collected: Nerve conduction } \\
\text { studies on a cross-sectional study group } \\
\text { of } 31 \text { male farmers who periodically } \\
\text { applied pesticides. }\end{array}$ & $\begin{array}{l}\text { All nerve conduction studies (on the median, ulnar, posterior } \\
\text { tibial, peroneal, and sural nerves) remained within laboratory } \\
\text { normal limits. }\end{array}$ \\
\hline
\end{tabular}




\begin{tabular}{|c|c|c|c|}
\hline Reference & Main conclusions & Data & Quantitative Results \\
\hline $\begin{array}{l}\text { Peiris-John et al. } \\
\qquad(2002)\end{array}$ & $\begin{array}{l}\text { Long-term low-level exposure to organophosphate pesticides is } \\
\text { associated with sensory and motor impairment. }\end{array}$ & $\begin{array}{l}\text { Data collected: } 30 \text { farmers who regularly } \\
\text { spray organophosphate pesticides and } \\
30 \text { fishermen (controls). }\end{array}$ & $\begin{array}{l}\text { Significant differences between farmers and controls found in: } \\
\text { sensory conduction velocity }(P=0.04) \text {; motor conduction velocity } \\
\qquad(P=0.04) .\end{array}$ \\
\hline $\begin{array}{l}\text { Roldan-Tapia et } \\
\text { al. (2005) }\end{array}$ & $\begin{array}{l}\text { There is a significant association of long-term exposure to } \\
\text { carbamates and organophosphates and worse performance in } \\
\text { neuropsychological functions. }\end{array}$ & $\begin{array}{l}\text { Data collected in southeastern Spain } \\
\text { from March and April } 1998: 26 \text { in the } \\
\text { control group and } 40 \text { in the exposed } \\
\text { group. }\end{array}$ & $\begin{array}{l}\text { Effect of cumulative exposure in worsening: perceptive function } \\
\text { performance (OR=6.93); visuomotor praxis }(\mathrm{OR}=5.00) ; \\
\text { integrative task performance ( } \mathrm{OR}=4.12)\end{array}$ \\
\hline $\begin{array}{l}\text { Roldan-Tapia et } \\
\text { al. (2006) }\end{array}$ & $\begin{array}{c}\text { Acutely poisoned long-term workers and chronically high exposed } \\
\text { workers exhibit similar disturbances in perception and visuomotor } \\
\text { processing. }\end{array}$ & $\begin{array}{l}\text { Data collected in southeastern Spain: } 26 \\
\text { in the control group, } 40 \text { in the non- } \\
\text { poisoned but exposed group, and } 24 \text { in } \\
\text { the acutely poisoned group }\end{array}$ & $\begin{array}{l}\text { Tests where acutely poisoned group performed worse than the } \\
\text { control group: Picture completion, rey-auditory verbal learning } \\
\text { test, logical memory, rey-osterrieth figure test, and benton visual } \\
\text { form test. }\end{array}$ \\
\hline $\begin{array}{l}\text { Rothlein et al. } \\
\quad(2006)\end{array}$ & $\begin{array}{l}\text { Evidence regarding a lower neurobehavioral performance of } \\
\text { Hispanic immigrant farmworkers is found, compared to } \\
\text { nonagricultural Hispanic immigrant population. }\end{array}$ & $\begin{array}{l}\text { Data collected: } 96 \text { farmworkers recruited } \\
\text { by community members of the Migrant } \\
\text { Head Start program in Hood River, } \\
\text { between } 20 \text { and } 52 \text { year old, and } \\
\text { originally from Mexico. }\end{array}$ & $\begin{array}{c}\text { Mean scores of different tests with significant differences } \\
\text { between agricultural and nonagricultural subjects: Digit span } \\
\text { backward (3.86 vs 4.53); Finger tapping [females] (81.68 vs } \\
90.41) \text {. }\end{array}$ \\
\hline $\begin{array}{l}\text { Sathiakumar et al. } \\
\qquad(2004)\end{array}$ & $\begin{array}{l}\text { The results are consistent with the absence of an association } \\
\text { between triallate and measures of neurological function. }\end{array}$ & $\begin{array}{l}\text { Data collected: } 349 \text { subjects working at } \\
\text { a plant. Selection of } 50 \text { with the highest } \\
\text { triallate scores and } 50 \text { with no-exposure. }\end{array}$ & $\begin{array}{l}\text { Mean sural nerve peak amplitude comparison: } \\
\text { High-exposed: } 11.7 \text { vs No-exposed: } 15.2(\mathrm{p}=0.03) \\
\text { After adjusting for other potential risk: } \\
\text { High-exposed: } 12.5 \text { vs No-exposed: } 14.5(\mathrm{p}=0.25)\end{array}$ \\
\hline $\begin{array}{l}\text { Schultz et al. } \\
\quad(2013)\end{array}$ & $\begin{array}{l}\text { Cognitive ability declines faster in people with occupational } \\
\text { pesticide exposure compared to their unexposed counterparts. }\end{array}$ & $\begin{array}{l}\text { Data collected: } 18 \text { subjects with } \\
\text { occupational pesticide exposure and } 35 \\
\text { controls. All of them white English native } \\
\text { speakers. }\end{array}$ & $\begin{array}{l}\text { Results of Mini-Mental Status Exam showed a significant } \\
\text { negative correlation with age only for subjects with occupational } \\
\text { exposure }(r=-0.45, p<0.04)\end{array}$ \\
\hline Stallones(2006) & $\begin{array}{l}\text { Results suggest an association between pesticide exposed } \\
\text { occupations and suicides. However, this association is significant } \\
\text { only for women. }\end{array}$ & $\begin{array}{l}\text { Data collected: } 4,991 \text { suicide deaths } \\
\text { and } 107,692 \text { other deaths in Colorado } \\
\text { between } 1990 \text { and } 1999 .\end{array}$ & $\begin{array}{l}95 \% \mathrm{Cl} \text { of odds ratios of suicide associated to occupational } \\
\text { pesticide exposure: men }(0.97,1.34) \text {; women }(1.01,3.88) \text {. }\end{array}$ \\
\hline $\begin{array}{l}\text { Starks et al. } \\
\quad(2012)\end{array}$ & $\begin{array}{l}\text { Evidence linking high pesticide exposure events (HPEE) and } \\
\text { adverse central nervous system outcomes is found. }\end{array}$ & $\begin{array}{l}\text { Agricultural Health Study: } 156 \text { male } \\
\text { participants (from } 2006 \text { to 2008) with a } \\
\text { HPEE, and } 537 \text { controls completed } 9 \\
\text { neurobehavioral tests. }\end{array}$ & $\begin{array}{l}\text { Participants reporting a HPEE were } 4.2 \mathrm{~s} \mathrm{slower} \mathrm{in} \mathrm{a} \mathrm{processing} \\
\text { test, and } 2.5 \mathrm{~s} \text { slower in a motor speed test. }\end{array}$ \\
\hline $\begin{array}{l}\text { Starks et al. } \\
(2012 \mathrm{~b})\end{array}$ & $\begin{array}{l}\text { Significant evidence associating long-term organophosphate } \\
\text { pesticides and impaired Peripheral Nervous System function. }\end{array}$ & $\begin{array}{l}\text { Agricultural Health Study: } 1,807 \text { eligible } \\
\text { subjects, with a } 39 \% \text { participation rate } \\
\text { (in lowa and North Carolina). }\end{array}$ & $\begin{array}{l}\text { Ten out of } 16 \text { OP pesticides associated with at least one } \\
\text { Neurological Physical Examination outcome. } 6 \text { OP pesticides } \\
\text { were associated with abnormal toe proprioception, with odds } \\
\text { ratios ranging from } 2.03 \text { to } 3.06 \text {. }\end{array}$ \\
\hline $\begin{array}{l}\text { Steenland et al. } \\
\text { (2013) }\end{array}$ & $\begin{array}{l}\text { Elderly subjects with past occupational pesticide exposure are } \\
\text { associated with a higher risk for dementia and Parkinson's disease } \\
\text { (PD). }\end{array}$ & $\begin{array}{l}\text { Data collected: } 400 \text { elderly subjects at } \\
\text { two government-run clinics in Costa } \\
\text { Rica. } 361 \text { of them did two different tests, } \\
\text { and } 144 \text { were examined by a } \\
\text { neurologist. }\end{array}$ & $\begin{array}{l}\text { Exposed subjects have significant higher risk of abnormal scores } \\
\text { on tremor-at-rest test }(\mathrm{OR}=2.58) \text {, on finger-tapping }(\mathrm{OR}=2.94) \text {, } \\
\text { and an increased risk of } \mathrm{PD}(\mathrm{OR}=2.57) .\end{array}$ \\
\hline $\begin{array}{l}\text { Van Wijngaarden } \\
\text { (2003) }\end{array}$ & $\begin{array}{l}\text { Employment in jobs involving pesticide exposure is associated with } \\
\text { the risk of death from mental disorders. }\end{array}$ & $\begin{array}{l}\text { Data collected: } 7,756 \text { deaths from } \\
\text { mental disorders and } 330,452 \text { controls. } \\
\text { Data comes from US death certificates } \\
\text { (1988-1992). }\end{array}$ & $\begin{array}{l}\text { Significant odds ratios of the risk of death due to mental } \\
\text { disorders associated with pesticide exposure: } 1.46 \text { (all); } 2.65 \\
\text { (women); } 4.32 \text { (women dying from neurotic disorders). }\end{array}$ \\
\hline $\begin{array}{l}\text { Zhang et al. } \\
\text { (2009) }\end{array}$ & $\begin{array}{l}\text { Potential markers of chronic pesticide exposure is significantly } \\
\text { associated with suicidal ideation. }\end{array}$ & $\begin{array}{l}\text { Data collected: survey with } 9,811 \text { rural } \\
\text { residents in Zhejiang province. }\end{array}$ & $\begin{array}{c}\text { Significant effect of pesticide storage at home with suicidal } \\
\text { ideation over the prior } 2 \text { years: Unadjusted OR=2.12; Adjusted } \\
\text { OR=1.63. }\end{array}$ \\
\hline & & & Continue on the next page \\
\hline
\end{tabular}




\begin{tabular}{|c|c|c|c|}
\hline Reference & Main conclusions & Data & Quantitative Results \\
\hline \multicolumn{4}{|c|}{ DIABETES } \\
\hline Cox et al. (2007) & $\begin{array}{l}\text { Higher serum levels of certain organochlorine pesticides may be } \\
\text { associated with increased prevalence of diabetes. }\end{array}$ & $\begin{array}{c}\text { Hispanic Health and Nutrition } \\
\text { Examination Survey: } 1,303 \text { Mexican } \\
\text { Americans between } 20 \text { and } 74 \text { years of } \\
\text { age. }\end{array}$ & $\begin{array}{l}95 \% \mathrm{Cl} \text { of crude odds ratios for different pesticides: } \\
\text { Hexachlorobenzene (1.2,2.3); Dieldrin (1.8,18.5); trans- } \\
\text { Nonachlor }(3.2,11.9) ; \text { Oxychlordane }(2.9,15.8) ; \text {; p p'-DDT } \\
\text { (2.0,8.4); p,p'-DDE }(2.9,14.7) ; \mathrm{B}-\mathrm{HCH}(2.9,15.8)\end{array}$ \\
\hline $\begin{array}{l}\text { Montgomery et al. } \\
\qquad(2008)\end{array}$ & $\begin{array}{l}\text { Long-term exposure from handling certain pesticides, in particular } \\
\text { organochlorine and organophosphate insecticides, may be } \\
\text { associated with increased risk of diabetes. }\end{array}$ & $\begin{array}{l}\text { Agricultural Health Study: } 33,457 \\
\text { licensed applicators in lowa and North } \\
\text { Carolina. }\end{array}$ & $\begin{array}{c}\text { Statistical significant adjusted odds ratios (at 95\%): } \\
\text { Chlordane: 1.16; Heptachlor: } 1.20 \text {; Coumaphos: } 1.26 \text {; Phorate: } \\
\text { 1.22; Terbufos: 1.17; Trichlorfon: } 1.85\end{array}$ \\
\hline $\begin{array}{l}\text { Saldana et al. } \\
\qquad(2007)\end{array}$ & $\begin{array}{c}\text { Activities involving exposure to agricultural pesticides during the } \\
\text { first trimester of pregnancy may increase the risk of gestational } \\
\text { diabetes mellitus (GDM). }\end{array}$ & $\begin{array}{l}\text { Agricultural Health Study: } 11,273 \\
\text { women whose pregnancy occurred } \\
\text { within } 25 \text { years of enrollment. }\end{array}$ & $\begin{array}{l}\quad 95 \% \mathrm{Cl} \text { of odds ratios: } \\
\text { Agricultural pesticide exposure: } 1.5-3.3 \\
\text { Residential pesticide exposure: } 0.8-1.3\end{array}$ \\
\hline \multicolumn{4}{|c|}{ RESPIRATORY } \\
\hline Boers et al. (2008) & $\begin{array}{l}\text { No significant association between exposure to } \\
\text { ethylenebisdithiocarbamates or other pesticides and asthma is } \\
\text { found. }\end{array}$ & $\begin{array}{l}\text { Data collected: From } 5 \text { field studies (in } \\
\text { the Netherlands, Italy, Finland, and } \\
\text { Bulgaria[2]). } 248 \text { workers exposed to } \\
\text { pesticides and } 231 \text { controls. }\end{array}$ & $\begin{array}{l}\text { No significant results for associations between occupational } \\
\text { exposure to pesticides and asthma (OR=0.41), chest tightness } \\
(\mathrm{OR}=0.60) \text {, wheeze }(\mathrm{OR}=0.56) \text {, or asthma attack }(0.52) \text {. }\end{array}$ \\
\hline $\begin{array}{l}\text { Fieten et al. } \\
\quad(2009)\end{array}$ & $\begin{array}{l}\text { Although the present study could not establish a causal relation, it } \\
\text { does suggests association between exposure to pesticides and } \\
\text { respiratory symptoms. The major limitation is the small study } \\
\text { population and lack of quantitative exposure estimates. }\end{array}$ & $\begin{array}{l}\text { Cross-sectional study among a } \\
\text { population of indigenous women in } \\
\text { Costa Rica ( } 69 \text { exposed women, and } 58 \\
\text { unexposed). }\end{array}$ & $\begin{array}{c}\text { Statistically significant odd ratios for wheeze: } \\
\text { Chlorpyrifos: 2.7; Terbufos (smoking): 2.8; Chlorpyrifos } \\
\text { (smoking): } 3.5 ; \text { Terbufos (non-smokers): } 5.9 ; \text { Chlorpyrifos (non- } \\
\text { smokers): } 6.7\end{array}$ \\
\hline $\begin{array}{l}\text { Hernandez et al. } \\
\qquad(2008)\end{array}$ & $\begin{array}{l}\text { Exposure to certain pesticides is associated to a fall in the diffusing } \\
\text { capacity of the lungs and with lower pulmonary volumes. }\end{array}$ & $\begin{array}{l}\text { Data collected: } 89 \text { pesticide sprayers } \\
\text { and } 25 \text { nonspraying control farmers } \\
\text { from the south of Spain. }\end{array}$ & $\begin{array}{l}\text { Significant increase in the risk of presenting respiratory } \\
\text { symptoms due to the exposure to endosulfan: OR=3.68 }(95 \% \mathrm{Cl} \text { : } \\
1.16,11.68)\end{array}$ \\
\hline $\begin{array}{l}\text { Hoppin et al. } \\
\quad(2002)\end{array}$ & $\begin{array}{l}\text { There is evidence that some pesticides may contribute to } \\
\text { respiratory symptoms among farmers, specifically there are some } \\
\text { pesticides associated to wheeze. }\end{array}$ & $\begin{array}{l}\text { Agricultural Health Study: } 20,468 \\
\text { licensed applicators in lowa and North } \\
\text { Carolina. }\end{array}$ & $\begin{array}{c}\text { Statistically significant odd ratios for wheeze: } \\
\text { Alachlor: 1.24; Altrazine: } 1.20 ; \text { Chlorimuron ethyl: } 1.14 \text {; Paraquat: } \\
\text { 1.27; Petroleum oil: } 1.28 \text {; Permethrin: } 1.26\end{array}$ \\
\hline $\begin{array}{l}\text { Hoppin et al. } \\
\text { (2006) }\end{array}$ & $\begin{array}{l}\text { Organochlorine and carbamate pesticides should be further } \\
\text { evaluated as potential risk factors for farmer's lung. }\end{array}$ & $\begin{array}{l}\text { Agricultural Health Study: } 50,000 \\
\text { farmers and farmer's spouses in lowa } \\
\text { and North Carolina. }\end{array}$ & $\begin{array}{l}\text { Statistically significant odd ratios for farmer's lung: } \\
\text { Handling silage: } 1.41 \text {; High pesticide exposure events: } 1.75 \text {; Use } \\
\text { of Organochlorine: } 1.34 \text {; Use of Carbamate: } 1.32\end{array}$ \\
\hline $\begin{array}{l}\text { Hoppin et al. } \\
\text { (2006b) }\end{array}$ & $\begin{array}{l}\text { The results of this study suggest a link between respiratory health } \\
\text { and organophopshate insecticides such as chlorimuron-ethyl. }\end{array}$ & $\begin{array}{l}\text { Agricultural Health Study: } 2,255 \text { lowa } \\
\text { commercial pesticide applicators. }\end{array}$ & $\begin{array}{l}\text { Significant increasing dose-response trends: Chlorimuron-ethyl: } \\
\text { p-trend = 0.012; Chlorpyrifos: } p \text {-trend }=0.003 \text {; Phorate: } p \text {-trend = } \\
0.010 .\end{array}$ \\
\hline $\begin{array}{l}\text { Hoppin et al. } \\
(2007)\end{array}$ & $\begin{array}{l}\text { The findings of this study suggest that pesticides may contribute to } \\
\text { atopic asthma among farm women. }\end{array}$ & $\begin{array}{l}\text { Agricultural Health Study: } 25,814 \text { farm } \\
\text { women in lowa and North Carolina. }\end{array}$ & $\begin{array}{l}\text { 95\% Cl of odds ratios for atopic asthma: } \\
\text { Use of pesticides: } 1.14-1.87 \\
\text { Grew up on farm \& did not apply pesticides: } 0.27-0.62\end{array}$ \\
\hline
\end{tabular}




\begin{tabular}{|c|c|c|c|}
\hline Reference & Main conclusions & Data & Quantitative Results \\
\hline $\begin{array}{l}\text { Hoppin et al. } \\
\text { (2007b) }\end{array}$ & $\begin{array}{l}\text { This study provide preliminary evidence that pesticide use may } \\
\text { increase chronic bronchitis prevalence. }\end{array}$ & $\begin{array}{l}\text { Agricultural Health Study: } 20,908 \text { private } \\
\text { pesticide applicators in lowa and North } \\
\text { Carolina. }\end{array}$ & $\begin{array}{c}95 \% \mathrm{Cl} \text { of odds ratios for chronic bronchitis: } \\
\text { Heptachlor: } 1.19-1.89 \\
\text { High exposure event: } 1.51-2.25 \\
\text { Pesticide use in off-farm jobs: } 1.04-1.88\end{array}$ \\
\hline $\begin{array}{l}\text { Hoppin et al. } \\
\quad(2009)\end{array}$ & $\begin{array}{l}\text { This study contribute with the literature suggesting that pesticides } \\
\text { may increase asthma risk among farmers. }\end{array}$ & $\begin{array}{l}\text { Agricultural Health Study: } 19,704 \text { male } \\
\text { farmers in lowa and North Carolina. }\end{array}$ & $\begin{array}{l}\text { Significant odds ratios for allergic asthma (>2): } \\
\text { Coumaphos: 2.34; Heptachlor: 2.01; Parathion: 2.05; Carbon } \\
\text { tetrachloride/disulfide: } 2.15 \text {; Ethylene dibromide: } 2.07\end{array}$ \\
\hline $\begin{array}{l}\text { Mekonnen et al. } \\
\text { (2002) }\end{array}$ & $\begin{array}{l}\text { Farm workers in various job categories are subject to reduced } \\
\text { pulmonary function and present respiratory symptoms that could } \\
\text { lead to chronic respiratory health problems. }\end{array}$ & $\begin{array}{l}\text { Data collected: } 103 \text { sprayers, } 15 \\
\text { supervisors, } 14 \text { technicians, } 19 \text { pest } \\
\text { assessors, and } 80 \text { controls at Ethiopia. }\end{array}$ & $\begin{array}{l}\text { Prevalence of respiratory symptoms among non-smoker farm } \\
\text { workers: Breathlessness: Sprayers } 16.5 \% \text {; Supervisors } 26.7 \% \text {; } \\
\text { Technicians } 35.7 \% \text {; Pest assessors 10.5\%; Controls } 16.3 \%\end{array}$ \\
\hline $\begin{array}{l}\text { Salameh et al. } \\
\quad(2006)\end{array}$ & $\begin{array}{l}\text { The results suggest that occupational exposure to pesticides may } \\
\text { explain chronic respiratory symptoms and asthma }\end{array}$ & $\begin{array}{l}\text { Data collected: } 186 \text { case and } 186 \\
\text { control subjects coming from } 10 \text { medical } \\
\text { centers in all Lebanese regions. }\end{array}$ & $\begin{array}{l}\text { Significant association between any pesticide exposure and } \\
\text { asthma }(\mathrm{OR}=2.11) \text {, occupational exposure and asthma } \\
(\mathrm{OR}=4.98) \text {, and regional exposure and asthma (OR=3.51). }\end{array}$ \\
\hline $\begin{array}{l}\text { Slager et al. } \\
\text { (2009) }\end{array}$ & Exposure to pesticides may increase the risk of rhinitis. & $\begin{array}{l}\text { Agricultural Health Study: } 2,245 \text { lowa } \\
\text { commercial pesticide applicators. }\end{array}$ & $\begin{array}{c}\text { Significant odds ratios for rhinitis: } \\
\text { 2,4-D: } 1.34 \text {; Glyphosate: } 1.32 \text {; Petroleum oil: } 1.74 \text {; Diazinon: } \\
\text { 1.84; Fungicide benomyl: } 2.35\end{array}$ \\
\hline $\begin{array}{l}\text { Sutoluk et al. } \\
\quad(2011)\end{array}$ & $\begin{array}{l}\text { Chronic environmental organophosphorus exposure causes a } \\
\text { decrease in the serum chlorinesterase levels in farm workers, but } \\
\text { has no effect on pulmonary functions }\end{array}$ & $\begin{array}{l}\text { Data collected: } 50 \text { male seasonal farm } \\
\text { workers and } 50 \text { male non-farm workers } \\
\text { located in Cukurova region, Turkey } \\
\text { (2007). }\end{array}$ & $\begin{array}{l}\text { Mean serum cholinesterase enzyme levels are significantly lower } \\
\text { for the farm group (7095.5) than for the non-farm group (9716.4). }\end{array}$ \\
\hline \multicolumn{4}{|c|}{ WOMEN SPECIFIC DISORDERS } \\
\hline $\begin{array}{l}\text { Akkina et al. } \\
\text { (2004) }\end{array}$ & $\begin{array}{l}\text { High exposure to organochlorine pesticides is associated with a } \\
\text { decrease in the mean age at menopause. }\end{array}$ & $\begin{array}{l}\text { Hispanic Health and Nutrition } \\
\text { Examination Survey: } 219 \text { menopausal } \\
\text { women (1982-1984). }\end{array}$ & $\begin{array}{l}\text { Significant reduction on the years to menopause for women with } \\
\text { high exposure to pesticides: between } 3.4 \text { and } 5.7 \text { years earlier } \\
\text { depending on the pesticide. }\end{array}$ \\
\hline Farr et al. (2004) & $\begin{array}{l}\text { The findings of this study suggest that use of certain hormonally } \\
\text { active pesticides may affect menstrual cycles. }\end{array}$ & $\begin{array}{l}\text { Agricultural Health Study: } 3,103 \text { women } \\
\text { living on farms in lowa and North } \\
\text { Carolina. }\end{array}$ & $\begin{array}{c}\text { Significant odds ratios. Use of pesticides on missed period: } 1.6 ; \\
\text { Carbamate use on long menstrual cycle: } 2.1 \text {; Crop insecticide on } \\
\text { missed period: } 1.6 ; \text { : Use of hormonally active pesticides had a } 60- \\
100 \% \text { increased odds of experiencing long cycles, missed } \\
\text { periods, and intermenstrual bleeding compared with no use of } \\
\text { pesticides }\end{array}$ \\
\hline Farr et al. (2006) & Pesticide use may be associated with a larger age at menopause. & $\begin{array}{l}\text { Agricultural Health Study: } 8,038 \text { women } \\
\text { living and working on farms in lowa and } \\
\text { North Carolina. }\end{array}$ & $\begin{array}{l}\text { Increased median time to menopause when using pesticides: } 3 \\
\text { months. Increased median time to menopause when using } \\
\text { hormonally active pesticides: } 5 \text { months. }\end{array}$ \\
\hline $\begin{array}{l}\text { Lauria et al. } \\
\quad(2006)\end{array}$ & $\begin{array}{l}\text { Pregnancies with delayed conception are associated to pesticide } \\
\text { exposure, but the results are not significant when adjusting for } \\
\text { confounding variables. }\end{array}$ & $\begin{array}{l}\text { Data collected: } 713 \text { women active in } 34 \\
\text { greenhouse flower growing enterprises } \\
\text { in } 1998-2000 .\end{array}$ & $\begin{array}{l}\text { Non-significant hazard ratio for reduced fertility among the group } \\
\text { exposed to pesticides ( } \mathrm{HR}=0.96 .95 \% \mathrm{Cl}: 0.81,1.13 \text { ). }\end{array}$ \\
\hline $\begin{array}{l}\text { Saldana et al. } \\
\text { (2009) }\end{array}$ & $\begin{array}{l}\text { Exposure to pesticides during pregnancy may increase the risk of } \\
\text { hypertensive disorders of pregnancy. }\end{array}$ & $\begin{array}{l}\text { Agricultural Health Study: } 11,274 \text { wives } \\
\text { of farmers from lowa and North Carolina } \\
\text { (1993-1997). }\end{array}$ & $\begin{array}{l}\text { First-trimester agricultural activities with potential exposure to } \\
\text { pesticides are significantly associated with: pregnancy-induced } \\
\text { hypertension }(\mathrm{aOR}=1.60) \text { and preeclampsia }(\mathrm{aOR}=2.07) \text {. }\end{array}$ \\
\hline
\end{tabular}




\begin{tabular}{|c|c|c|c|}
\hline Reference & Main conclusions & Data & Quantitative Results \\
\hline \multicolumn{4}{|c|}{ GENERAL HEALTH, MULTIPLE DISEASES AND OTHERS } \\
\hline Azmi et al. (2006) & $\begin{array}{l}\text { Exposure to multiple pesticides for prolonged period affects the } \\
\text { normal functioning of different organ systems and possibly has } \\
\text { clinical effects such as hepatitis, dyspnea and burning sensation in } \\
\text { urine. }\end{array}$ & $\begin{array}{l}\text { Blood samples from } 83 \text { farm workers } \\
\text { from } 14 \text { different fruit and vegetable } \\
\text { farm stations located in the } \\
\text { surroundings of Gadap (Pakistan). }\end{array}$ & $\begin{array}{r}\text { t-statistics (P-values) for differences in enzyme (GOT, GPT, ALP) } \\
\text { levels unexposed vs exposed: GPT: -2.57 (0.62); GOT: }-3.20 \\
\text { (0.033); ALP: }-7.3(0.0019)\end{array}$ \\
\hline $\begin{array}{l}\text { Baranska et al. } \\
\quad(2008)\end{array}$ & $\begin{array}{l}\text { The study identify individuals within the group of pesticide exposed } \\
\text { workers with a genetic polymorphism who show a lower antibody } \\
\text { response. }\end{array}$ & $\begin{array}{l}\text { Data collected: } 238 \text { workers } \\
\text { occupationally exposed to pesticides, } \\
\text { and } 198 \text { controls, in four European } \\
\text { countries. }\end{array}$ & $\begin{array}{l}\text { Significantly lower mean anti-HB antibody levels for exposed } \\
\text { subjects (1.72) than for controls (3.08), with IL1alpha2.2 } \\
\text { polymorphic gene expression. }\end{array}$ \\
\hline Beard et al. (2003) & $\begin{array}{l}\text { The findings of this study suggest an association between adverse } \\
\text { health effects (asthma, diabetes, pancreatic cancer, leukemia, } \\
\text { lower neuropsychologic functioning scores, and diabetes) and } \\
\text { exposure to pesticides. }\end{array}$ & $\begin{array}{l}\text { Comparison of mortality off } 1,999 \\
\text { outdoor staff with pesticide exposure, } \\
1,984 \text { outdoor workers not exposed, and } \\
\text { Australian population average levels. }\end{array}$ & $\begin{array}{c}95 \% \mathrm{Cl} \text { of standardized mortality ratios: } \\
\text { asthma: } 1.39-7.10 \text {; diabetes: } 1.16-8.32 \text {; pancreatic cancer: } \\
1.09-15.40 \text {; leukemia (incidence ratio for modern chemicals): } \\
1.54-284.41\end{array}$ \\
\hline Beard et al. (2011) & $\begin{array}{l}\text { There is no association between prior pesticide use and suicide in } \\
\text { applicators and their spouses. }\end{array}$ & $\begin{array}{l}\text { Agricultural Health Study: } 110 \text { suicides } \\
\text { between } 1993 \text { and } 2009, \text { among } 81,998 \\
\text { cohort members (in lowa and North } \\
\text { Carolina). }\end{array}$ & $\begin{array}{l}95 \% \mathrm{Cl} \text { of Hazard ratios based on the days per year personally } \\
\text { mixed or applied pesticides (none }=\text { reference): } \\
\text { less than } 20(0.42,2.28) ; \text { more than } 20(0.36,2.20)\end{array}$ \\
\hline $\begin{array}{l}\text { Crawford et al. } \\
\quad(2008)\end{array}$ & $\begin{array}{l}\text { Control for exposure to noise and other neurotoxicants is limited, } \\
\text { however the results extend previous reports suggesting that } \\
\text { organophosphate exposure increases the risk of hearing loss. }\end{array}$ & $\begin{array}{l}\text { Agricultural Health Study: } 14,299 \text { white } \\
\text { male pesticide applicators in lowa and } \\
\text { North Carolina. }\end{array}$ & $\begin{array}{c}\text { Significant odds ratios for hearing loss: } \\
\text { All insecticides: } 1.19 ; \text { Organophosphate insecticides: } 1.17 ; \text { High } \\
\text { pesticide exposure events: } 1.38 ; \text { Hospitalization: } 1.81 ; \text { Diagnosed } \\
\text { pesticide poisoning: } 1.75\end{array}$ \\
\hline $\begin{array}{l}\text { Dayton et al. } \\
\text { (2010) }\end{array}$ & $\begin{array}{l}\text { Pesticides may contribute to Myocardial Infarction (MI) risk among } \\
\text { farm women. }\end{array}$ & $\begin{array}{l}\text { Agricultural Health Study: } 22,425 \text { farm } \\
\text { women in lowa and North Carolina. }\end{array}$ & $\begin{array}{c}\text { Significant odds ratios for non-fatal MI: } \\
\text { Chlorpyrifos: 2.1; Coumaphos: } 3.2 \text {; Carbofuran: } 2.5 \text {; Metalaxyl: } \\
\text { 2.4; Pendimethalin: } 2.5 \text {; Trifluralin: } 1.8\end{array}$ \\
\hline $\begin{array}{l}\text { Del Prado-Lu } \\
\quad(2007)\end{array}$ & $\begin{array}{l}\text { The findings of this study are further proof of the hematoxic effects } \\
\text { of pesticide exposure. There exists a detrimental effect of } \\
\text { pesticide exposure on RBC cholinesterase levels. }\end{array}$ & $\begin{array}{l}\text { Data collected: } 102 \text { randomly selected } \\
\text { cutflower farmers in La trinidad, } \\
\text { Benguet. }\end{array}$ & $\begin{array}{l}\text { P-values for significant variables explaining abnormal RBC } \\
\text { cholinesterase levels: } \\
\text { Age: } p=0.02 ; \text { selling pesticide containers: } p=0.008 \text {; number of } \\
\text { years of using pesticides: } p=0.022 ; \text { use of contaminated cloth: } \\
p=0.033 \text {; illness due to pesticides: } p=0.005 \text {; improper mixing of } \\
\text { pesticides: } p=0.041 ; \text { sex: } p=0.002\end{array}$ \\
\hline $\begin{array}{l}\text { Fleming et al. } \\
\quad(2003)\end{array}$ & $\begin{array}{l}\text { Farmers and pesticide applicators have a greater risk of accidental } \\
\text { mortality than the rest of the workers. They also present an } \\
\text { increased risk of hematopoietic and nervous system cancers. }\end{array}$ & $\begin{array}{l}\text { National Health Interview Surveys } \\
\text { (NHIS): } 9,471 \text { farmers and } 438,228 \\
\text { controls in US }\end{array}$ & $\begin{array}{c}\text { Significant rate ratios for different causes of death: } \\
\text { All causes: } 1.3 ; \text { Heart diseases: } 1.4 ; \text { Nervous system cancer: } 2.4 \text {; } \\
\text { Hematopoietic cancer: } 2.2\end{array}$ \\
\hline $\begin{array}{l}\text { Goldner et al. } \\
\quad(2010)\end{array}$ & $\begin{array}{l}\text { The collected data support a role of organochlorines, in addition to } \\
\text { fungicides, in the etiology of thyroid disease among female } \\
\text { spouses enrolled in the AHS. }\end{array}$ & $\begin{array}{l}\text { Agricultural Health Study: } 16,529 \\
\text { spouses of pesticide applicators of lowa } \\
\text { and North Carolina. }\end{array}$ & $\begin{array}{l}\text { Significant adjusted odds ratios for hypothyroidism: } \\
\text { Organochlorine insecticides: } 1.2 \\
\text { Fungicides: } 1.4 \\
\text { Significant adjusted odds ratios for hyperthyroidism: } \\
\text { Maneb/mancozeb: } 2.3\end{array}$ \\
\hline $\begin{array}{l}\text { Gomez-Marin et } \\
\text { al. (2004) }\end{array}$ & $\begin{array}{l}\text { The present results indicate that at any point in time, compared to } \\
\text { other US workers, farmers are in general healthier, whereas, } \\
\text { despite the small numbers, pesticide applicators have a similar or } \\
\text { poorer health }\end{array}$ & $\begin{array}{l}\text { National Health Interview Surveys } \\
\text { (NHIS): } 9,576 \text { farmers and } 453,219 \\
\text { controls in US }\end{array}$ & $\begin{array}{c}\text { Significant odds ratios (and } 95 \% \mathrm{Cl} \text { ) for chronic disability (doctor } \\
\text { visit): } \\
\text { Farmers (vs other workers): } 0.82(0.76-0.88) \\
\text { Pesticide applicators (vs other workers): } 1.21(0.80-1.83)\end{array}$ \\
\hline
\end{tabular}




\begin{tabular}{|c|c|c|c|}
\hline Reference & Main conclusions & Data & Quantitative Results \\
\hline $\begin{array}{l}\text { Hernandez et al. } \\
\text { (2003) }\end{array}$ & $\begin{array}{l}\text { Chronic exposure to pesticides might be associated with serum } \\
\text { paraoxonase (PON1) decrease activity. }\end{array}$ & $\begin{array}{l}\text { Data collected: } 102 \text { individuals with long } \\
\text { term low dose exposure to pesticides in } \\
\quad \text { a plastic greenhouse setting. }\end{array}$ & $\begin{array}{c}\text { Significant differences between sprayers }(14.1 \%) \text { and non } \\
\text { sprayers }(5.1 \%) \text { were observed in the PON1-909 G/C } \\
\text { polymorphism }(p=0.045)\end{array}$ \\
\hline $\begin{array}{l}\text { Howard et al. } \\
(2010)\end{array}$ & $\begin{array}{l}\text { Single-nucleotide polymorphisms (SNPs) in the BCHE gene is } \\
\text { associated with pesticide exposure. }\end{array}$ & $\begin{array}{l}\text { Data collected: From the Community } \\
\text { ärticipatory Approach to Measuring } \\
\text { Farmworker Pesticide exposure: } 287 \\
\text { farmworkers recruited. }\end{array}$ & $\begin{array}{l}\text { Association of SNPs in BCHE with cholinesterase activity (FDR } \\
\text { adjusted } p \text {-values): } \\
\text { rs2668207 }(p=0.00098) \\
\text { rs2048493 ( } p=0.00068)\end{array}$ \\
\hline $\begin{array}{l}\text { Kesavachandran } \\
\text { et al. (2009) }\end{array}$ & $\begin{array}{l}\text { The findings of this study provide some evidence of clinical } \\
\text { manifestations because of multiple exposures to pesticides and } \\
\text { poor safety culture at work place. }\end{array}$ & $\begin{array}{l}\text { Data collected: detailed information was } \\
\text { recolleted through questionnaries from } \\
20 \text { subjects and controls in Uttar } \\
\text { Pradesh, India. }\end{array}$ & $\begin{array}{c}\text { Significant rate ratios for shopkeepers exposed to pesticides ( } p \\
\text { <0.05): Cardiovascular problems: } 3.36 ; \\
\text { Genito-urinary problems: } 8.64 ; \\
\text { Nervous system related problems: } 2.88 ; \\
\text { Skin problems: } 4.32 \text {. }\end{array}$ \\
\hline Khan et al. (2009) & $\begin{array}{l}\text { Unsafe practices among small and medium sized pesticides } \\
\text { industrial workers cause significant increase in pesticide exposure, } \\
\text { oxidative stress, and derangement of hepatic and renal function. }\end{array}$ & $\begin{array}{l}\text { Data collected: Plasma cholinesterase } \\
\text { (PChE) levels from } 238 \text { exposed } \\
\text { workers ( } 54 \text { controls) in Pakistan, } \\
\text { estimated by Ellmann's method. }\end{array}$ & $\begin{array}{l}\text { Significant }(p<0.05) \text { differences in biochemical markers between } \\
\text { size-exposed groups and control: } \\
\text { Hemoglobin: small (13.98); control (14.92) } \\
\text { Alanine aminotransferase: small (34); medium (31); control }(25) \\
\text { Asparate aminotransferase: small }(25) \text {; medium (27); control }(24)\end{array}$ \\
\hline $\begin{array}{l}\text { Kirrane et al. } \\
(2005)\end{array}$ & $\begin{array}{l}\text { The findings suggest that exposure to some fungicides and other } \\
\text { pesticides may increase the risk of retinal degeneration. }\end{array}$ & $\begin{array}{l}\text { Agricultural Health Study: } 31,173 \\
\text { farmers' wives in lowa and North } \\
\text { Carolina. }\end{array}$ & $\begin{array}{c}\text { Significant adjusted odds ratios and } 95 \% \mathrm{Cl} \text { for retinal } \\
\text { degeneration: } \\
\text { Fungicides (general): } 1.9(1.2-3.1)\end{array}$ \\
\hline $\begin{array}{l}\text { Lacasaña et al. } \\
\quad(2010)\end{array}$ & $\begin{array}{l}\text { Results suggest that the exposure to organophosphate pesticides } \\
\text { may affect the serum hormone levels, acting as endocrine } \\
\text { disruptors in humans. }\end{array}$ & $\begin{array}{l}\text { Data collected: } 136 \text { male subjects from } \\
\text { State of Mexico and Morelos, } \\
\text { occupationally exposed to } \\
\text { organophosphate pesticides. }\end{array}$ & $\begin{array}{c}\text { Significant increase in TSH and T4 hormones in serum } \\
\text { associated with increased exposure of pesticides } \\
\text { (dimethylphosphate, } p \text {-trend }<0.001) \text {, as well as a decrease in } \\
\text { T3 serum levels }(p \text {-trend }=0.053 \text { ). }\end{array}$ \\
\hline $\begin{array}{l}\text { Lacasaña et al. } \\
\quad(2010 \mathrm{~b})\end{array}$ & $\begin{array}{l}\text { The results suggest an interaction between organophosphate } \\
\text { pesticide exposure and thyroid function which is stronger for } \\
\text { individuals with lower paraoxonase-1 enzyme (PON1) activity. }\end{array}$ & $\begin{array}{l}\text { Data collected: during two periods (July- } \\
\text { Oct. } 2004 \text { and Dec. } 2004 \text { - May 2005) } \\
\text { for } 84 \text { workers. }\end{array}$ & $\begin{array}{c}\text { Significant variation (in \%) on the thyroid stimulating hormone for } \\
\text { each increment in one log unit of the dialkylphosphate metabolite } \\
\text { in the urine for: PON1(192)QR polymorphism (23\%); } \\
\text { PON1(192)RR polymorphism (59\%). }\end{array}$ \\
\hline $\begin{array}{l}\text { Landgren et al. } \\
\quad(2009)\end{array}$ & $\begin{array}{l}\text { The prevalence of monoclonal gammopathy of undetermined } \\
\text { significance (MGUS) among pesticide applicators was twice that in } \\
\text { a population-based sample of men from Minnesota. Specific } \\
\text { pesticides are causatively linked to myelomagenesis. }\end{array}$ & $\begin{array}{l}\text { Agricultural Health Study: stratified } \\
\text { random sample of } 678 \text { pesticide } \\
\text { applicators in lowa and North Carolina. }\end{array}$ & $\begin{array}{l}\text { Significant odds ratios for MGUS by pesticide: } \\
\text { Dieldrin: } 5.6 \\
\text { Carbon-tetrachloride / disulfide mix: } 3.9 \\
\text { Chlorthalonil: } 2.4\end{array}$ \\
\hline $\begin{array}{l}\text { Martin et al. } \\
\quad(2002)\end{array}$ & $\begin{array}{l}\text { Black farmers present lower exposure to pesticides than white } \\
\text { farmers as well as fewer pesticide-related symptoms. Black } \\
\text { farmers may also have other work practices that affect exposure } \\
\text { and risk. }\end{array}$ & $\begin{array}{l}\text { Agricultural Health Study: self- } \\
\text { administered questionnaires by } 891 \\
\text { black and } 11,909 \text { white farmers. }\end{array}$ & $\begin{array}{c}\text { Significant odds ratios (black vs white) for exposition to different } \\
\text { pesticides: } \\
\text { Herbicides: } 0.49 \text {; Insecticides: } 0.28 \text {; Fumigants: } 0.40 \text {; Fungicides } \\
0.82\end{array}$ \\
\hline $\begin{array}{l}\text { Melkonian et al. } \\
\text { (2011) }\end{array}$ & $\begin{array}{l}\text { Evidence found points to the significance of synergisms between } \\
\text { effects of arsenic exposure and pesticide/fertilizer use on incident } \\
\text { skin lesions. }\end{array}$ & $\begin{array}{l}\text { Health Effects of Arsenic Longitudinal } \\
\text { Study: } 5,042 \text { men from Araihazar, } \\
\text { Bangladesh recruited from } 2000 \text { to } \\
2002 \text {. }\end{array}$ & $\begin{array}{l}\text { Significant synergistic effects between fertilizer use and water } \\
\text { arsenic: } \text { Relative excess risk }=0.06(95 \% \mathrm{Cl}: 0.01,0.12) .\end{array}$ \\
\hline Mills et al. (2009) & $\begin{array}{l}\text { There is no evidence of a dose response with any pesticide } \\
\text { measure with respect to myocardial infarction (MI). However some } \\
\text { pesticides seems to be related to MI. }\end{array}$ & $\begin{array}{l}\text { Agricultural Health Study: 54,609 } \\
\text { pesticide applicators in lowa and North } \\
\text { Carolina. }\end{array}$ & $\begin{array}{c}\text { Significant }(p<0.05) \text { hazard ratios for MI by pesticide: } \\
\text { For MI mortality: Ethylene dibromide: } 1.54 \text {; Maneb: } 1.34 ; \text { Ziram: } \\
2.40 \\
\text { For MI incidence: Aldrin: } 1.20 \text {; DDT: } 1.24 ; 2,4,5-\mathrm{T}: 1.21\end{array}$ \\
\hline & & & Continue on the next page \\
\hline
\end{tabular}




\begin{tabular}{|c|c|c|c|}
\hline Reference & Main conclusions & Data & Quantitative Results \\
\hline $\begin{array}{l}\text { Murphy et al. } \\
\quad(2004)\end{array}$ & $\begin{array}{l}\text { Small scale West Sumatran female farmers apply pesticides } \\
\text { without personal protection in a highly unsafe manner. They found } \\
\text { striking the number of products that are handled on a weekly } \\
\text { basis, their human health hazard level and the fact that these are } \\
\text { handled during continuous growing seasons. }\end{array}$ & $\begin{array}{l}\text { Data collected from } 161 \text { women sprayer } \\
\text { (cases), and } 353 \text { rice farmers (controls), } \\
\text { in Indonesia. }\end{array}$ & $\begin{array}{l}\text { Significant relative risk for different symptoms: } \\
\text { Burning nose (53.2); Sore throat (18.5); Muscle cramps (10.6); } \\
\text { Nausea ( }(9.4) ; \text { Constipation (8.3); Eye burning }(7.3) \text {; Excessive } \\
\text { salivation (6.7); Dizzy (5.2); Blurred vision (4.4); Stomack pain } \\
\text { (2.7); Numbness (2.6); Dry throat (1.7); Shortness of breath (1.5) }\end{array}$ \\
\hline Ogut et al. (2011) & $\begin{array}{l}\text { The results suggest an association between chronic exposure to } \\
\text { pesticides and oxidative stress. }\end{array}$ & $\begin{array}{l}\text { Data collected: } 94 \text { pesticide-formulating } \\
\text { workers, and } 45 \text { controls. }\end{array}$ & $\begin{array}{c}\text { Chronic exposure to pesticides is significantly associated with } \\
\text { increased activities of catalase (17.40 vs } 29.22) \text {, of superoxide } \\
\text { dismutase (39.31 vs } 74.39) \text {, and others, reflecting oxidative } \\
\text { stress. }\end{array}$ \\
\hline Orton et al. (2011) & $\begin{array}{l}\text { All pesticides with previous evidence of androgen receptor } \\
\text { antagonism (14) are confirmed as antiandrogenic, along with } 9 \\
\text { previously untested pesticides. }\end{array}$ & $\begin{array}{l}37 \text { pesticides tested for invitro androgen } \\
\text { receptor antagonism. }\end{array}$ & $\begin{array}{l}\text { ERR - Environmental Relevance Ratios (Top 5): } \\
\text { Procymidone (202.5); Fenitrothion (112.2); Vinclozolin (79.8); } \\
\text { Dimethomorph (45.6); Fludiowonil (31.2). }\end{array}$ \\
\hline $\begin{array}{l}\text { Padungtod et al. } \\
\qquad(2000)\end{array}$ & $\begin{array}{l}\text { Exposure to specific organophosphate pesticides might have a } \\
\text { moderate adverse effect on semen quality }\end{array}$ & $\begin{array}{l}\text { Data collected: } 32 \text { male workers } \\
\text { occupationally exposed to pesticides } \\
\text { and } 43 \text { controls, from two nearby } \\
\text { factories in China. }\end{array}$ & $\begin{array}{l}\text { Significant reduction of sperm concentration (exposed: } \\
35.9^{\star} 10^{\wedge} 6 ; \text {; non-exposed: } 62.8^{\star} 10^{\wedge} 6 \text { ), and percentage of motility } \\
\text { (exposed: } 57 \% \text {; non-exposed: } 61 \% \text { ). }\end{array}$ \\
\hline Perry et al. (2011) & $\begin{array}{l}\text { An association between dimethylphosphate pesticide exposure } \\
\text { and low performance of sperm (in concentration and motility) is } \\
\text { found. }\end{array}$ & $\begin{array}{l}\text { Data collected: } 94 \text { cases and } 95 \\
\text { controls, recruited from July } 2003 \text { to } \\
\text { February } 2005 \text { in Anhui Province. }\end{array}$ & $\begin{array}{l}\text { Significant relative odds of case status for dimethylphosphate } \\
\text { exposure: aOR=1.30. Any other pesticide was non-significant. }\end{array}$ \\
\hline Recio et al. (2001) & $\begin{array}{l}\text { Organophosphorous pesticides (OP) might affect sperm } \\
\text { chromosome segregation and increase the risk for genetic } \\
\text { syndromes. }\end{array}$ & $\begin{array}{l}\text { Data collected: multicolor fluorescence } \\
\text { in situ hybridization on samples from } 9 \\
\text { men before and during pesticide } \\
\text { spraying season. }\end{array}$ & $\begin{array}{l}\text { Significant associations between diethylphosphate and sex null } \\
\text { (betha }=0.00022, p=0.0001) \text {. Smaller, but still significant } \\
\text { associations were found for other OP. }\end{array}$ \\
\hline Recio et al. (2005) & $\begin{array}{l}\text { The results suggest that organophosphorous pesticides (OP) } \\
\text { might disrupt the hypothalamic-pituitary endocrine function, and } \\
\text { the most affected hormones are the follicle-stimulating hormone } \\
\text { (FSH), and the luteinizing (LH). }\end{array}$ & $\begin{array}{l}\text { Data collected: } 64 \text { healthy men from } \\
\text { Villa Juarez, Durango, in Mexico, } \\
\text { provided the complete set of samples to } \\
\text { carry on the analysis. }\end{array}$ & $\begin{array}{l}\text { Significant effect of dimethylthiophosphate on LH levels (betha }=- \\
0.0002, p=0.008 \text { ), and on FSH levels (betha }=-0.002, p=0.0003 \text { ). }\end{array}$ \\
\hline $\begin{array}{l}\text { Sanchez-Pena et } \\
\text { al. (2004) }\end{array}$ & $\begin{array}{l}\text { Results suggest an association between organophosphate } \\
\text { pesticide exposure and alterations in the human sperm chromatin. }\end{array}$ & $\begin{array}{l}\text { Data collected: } 33 \text { agricultural workers } \\
\text { from the community of Villa Juarez, } \\
\text { Durango, in Mexico. }\end{array}$ & $\begin{array}{l}\text { The results are presented as mean values of the subjects } \\
\text { compared with reference values proposed in other studies. } 82 \% \\
\text { of the samples were above reference values proposed in the } \\
\text { literature. }\end{array}$ \\
\hline $\begin{array}{l}\text { Sekiyama et al. } \\
\quad(2007)\end{array}$ & $\begin{array}{l}\text { Precautionary measures have a significant impact on the analysis } \\
\text { of number of reported symptoms, therefore the role of formal } \\
\text { training and information on the use and handling of pesticides is } \\
\text { crucial. }\end{array}$ & $\begin{array}{l}\text { Data collected in } 2006 \text { at West Java, } \\
\text { Indonesia. } 73 \text { farmers from two villages } \\
\text { were enrolled in the study. }\end{array}$ & $\begin{array}{c}\text { Coefficients (p-value) for significant variables in the regression } \\
\text { analysis of number of reported symptoms: } \\
\text { Headgear use: } 0.315(0.005) ; \text { wet clothing: - } 0.280(0.012) ; \\
\text { smoking while spraying: }-0.262(0.017)\end{array}$ \\
\hline $\begin{array}{l}\text { Sprince et al. } \\
(2000)\end{array}$ & $\begin{array}{l}\text { Results confirming associations between respiratory symptoms } \\
\text { and conventional vertical silos may be important in future studies } \\
\text { aimed at prevention and control of exposures. There is also an } \\
\text { association between insecticide application and symptoms of } \\
\text { airways disease. }\end{array}$ & $\begin{array}{l}\text { lowa Farm Family Health and Hazard } \\
\text { Surveillance Project: } 385 \text { farmer } \\
\text { participants. }\end{array}$ & $\begin{array}{c}\text { Significant odds ratios for different symptoms: } \\
\text { Phlegm: } 1.91 ; \\
\text { Chest ever wheezy: } 3.92 \\
\text { Flu-like symptoms: } 2.93\end{array}$ \\
\hline $\begin{array}{l}\text { Strong et al. } \\
\quad(2004)\end{array}$ & $\begin{array}{l}\text { Certain self-reported health symptoms in farmworkers may be } \\
\text { associated with indicators of exposure to pesticides. }\end{array}$ & $\begin{array}{l}\text { Data collected: } 211 \text { households with } \\
\text { children between ages of } 2 \text { and } 6 \text { years } \\
\text { in Eastern Washington. }\end{array}$ & $\begin{array}{c}\text { Health symptoms most commonly reported: } \\
\text { Headaches: } 50 \% \\
\text { Burning eyes: } 39 \% \\
\text { Pain in muscles, joints, or bones: } 35 \% \\
\text { Rash or itchy skin: } 25 \% \\
\end{array}$ \\
\hline Swan (2006) & $\begin{array}{l}\text { The results suggest an association between current-use pesticides } \\
\text { and reduced semen quality (concentration and motility). }\end{array}$ & $\begin{array}{l}\text { Data collected: From } 493 \text { men from } \\
\text { Columbia, New York, Minneapolis, and } \\
\text { L.A., } 25 \text { with lower sperm quality were } \\
\text { selected as cases, and } 25 \text { with standard } \\
\text { sperm quality as controls. }\end{array}$ & $\begin{array}{c}\text { Men are significantly more likely to be cases if they presented } \\
\text { high levels of alachlor }(\mathrm{OR}=30 \text { ) and diazinon } \\
(\mathrm{OR}=16.7) \text { (compared to men with low levels), as well as men } \\
\text { with atrazine over the limit of detection (OR=11.3). }\end{array}$ \\
\hline
\end{tabular}


Table 2. Indirect exposure

\begin{tabular}{|c|c|c|c|}
\hline Reference & Main conclusions & Data & Quantitative Results \\
\hline \multicolumn{4}{|c|}{ CANCER } \\
\hline Brody et al. (2004) & $\begin{array}{l}\text { No overall association between pesticide use and breast } \\
\text { cancer is found. However, increases in risk of cancer is } \\
\text { associated with aerial application of persistent pesticides on } \\
\text { cranberry bogs, and less persistent pesticides applied for } \\
\text { agriculture. }\end{array}$ & $\begin{array}{l}\text { Data collected: } 1,165 \text { women residing in } \\
\text { Cape Cod, MA, diagnosed with breast cancer } \\
\text { (1988-1995) and 1,006 controls. Geographic } \\
\text { information system technology is used to } \\
\text { assess the exposure to pesticides. }\end{array}$ & $\begin{array}{l}\text { Just one significant association between pesticide } \\
\text { exposure (low) related to agriculture and higher risk of } \\
\text { cancer (5-year tumor promotion period assumed): } \\
\text { aOR=1.4 (95\% Cl: } 1.1-1.8) \text {. }\end{array}$ \\
\hline Carreon et al. (2005) & $\begin{array}{l}\text { Results show that exposure to pesticides is not associated } \\
\text { with an increased risk of intracranial gliomas in women. No } \\
\text { significant increase in risk of glioma is observed for } \\
\text { carbamate herbicides, similar to what is observed with } 12 \\
\text { specific pesticides. }\end{array}$ & $\begin{array}{l}\text { National Institute for Occupational Safety and } \\
\text { Health Upper Midwest Health Study: } 341 \\
\text { cases and } 528 \text { controls. }\end{array}$ & $\begin{array}{l}95 \% \mathrm{Cl} \text { of odd ratios for different pesticides: } \\
\text { Arsenicals }(0.5,1.9) ; \text { Benzoic acids }(0.4,1.5) ; \text { Carbamates } \\
(0.5,1.9) ; \text { Chloroacetanilides }(0.6,2.0) \text {; Dinitroanilines } \\
(0.4,1.5) \text {; Inorganics }(0.3,2.1) ; \text { Organochlorines }(0.7,1.8) ; \\
\text { Organophosphates }(0.6,1.5) \text {; Phenoxys }(0.5,1.5)\end{array}$ \\
\hline Cockburn et al. (2011) & $\begin{array}{c}\text { Evidence is found regarding an association between prostate } \\
\text { cancer and ambient pesticide exposures in and around } \\
\text { homes in intensely agricultural areas. }\end{array}$ & $\begin{array}{l}\text { Data collected: } 173 \text { cases and } 163 \text { controls } \\
\text { from the Central Valley, CA (2005-06).Past } \\
\text { exposure is estimated using a geographic } \\
\text { information system approach. }\end{array}$ & $\begin{array}{c}\text { Significant associations between higher prostate cancer } \\
\text { risk and exposure to: methyl bromide }(\mathrm{OR}=1.62) \text { and } \\
\text { organochlorines }(\mathrm{OR}=1.64) .\end{array}$ \\
\hline Ding et al. (2012) & $\begin{array}{l}\text { Pesticide exposure measured through urine tests may be } \\
\text { associated with an elevated risk of childhood acute } \\
\text { lymphocytic leukemia (ALL). }\end{array}$ & $\begin{array}{l}\text { Data collected: } 176 \text { children aged } 0-14 \text { years } \\
\text { and } 180 \text { matched controls (Shanghai, 2010- } \\
\text { 2011). }\end{array}$ & $\begin{array}{l}\text { Significant increased risk of ALL for the highest quartiles } \\
\text { of different metabolites level (compared to lowest } \\
\text { quartiles): total metabolites (OR=2.75); cis-DCCA } \\
\text { (OR=2.1); trans-DCCA (OR=2.21); 3PBA (OR=1.84). }\end{array}$ \\
\hline Engel et al. (2005) & $\begin{array}{l}\text { Some evidence of increased risk of breast cancer is found } \\
\text { when exposed to } 2,4,5-\mathrm{TP} \text {, dieldrin, captan, but small } \\
\text { numbers of cases are presented, so the results may not be } \\
\text { reliable. Risk is modestly elevated among women whose } \\
\text { homes are closest to areas of pesticide application. }\end{array}$ & $\begin{array}{l}\text { Agricultural Health Study: } 30,454 \text { farmers' } \\
\text { wives in lowa and North Carolina. }\end{array}$ & $\begin{array}{c}95 \% \mathrm{Cl} \text { of rate ratios for different pesticides: } \\
\text { Any pesticides (0.7,1.1); Dieldrin }(1.1,3.3) ; 2,4,5-\mathrm{TP} \\
(1.2,3.2) ; \text { Captan }(1.7,4.3)\end{array}$ \\
\hline Ferreira et al. (2013) & $\begin{array}{c}\text { Results suggest that pesticide exposure during pregnancy } \\
\text { may be involved in the etiology of acute leukemia in children } \\
\text { under } 2 \text { years of age. }\end{array}$ & $\begin{array}{l}\text { Data collected: Mothers of } 252 \text { cases and } \\
423 \text { controls located in one of } 13 \text { Brazilian } \\
\text { states, during } 1999-2007 \text {. }\end{array}$ & $\begin{array}{c}\text { Significant associations of pesticide use during } \\
\text { pregnancy and higher risk of: acute lymphoid leukemia } \\
(\mathrm{aOR}=2.10) \text { and acute myeloid leukemia (aOR=5.01) for } \\
0-11 \text { month-old kids; acute lymphoid leukemia } \\
\text { (aOR=1.88) for } 12-23 \text { month-old kids. }\end{array}$ \\
\hline Flower et al. (2004) & $\begin{array}{l}\text { Risk of all childhood cancers combined increases, as well as } \\
\text { risk of all lymphomas combined, and Hodgkin's lymphoma. } \\
\text { Increased risk of cancer is detected among children whose } \\
\text { fathers do not use chemically resistant gloves. }\end{array}$ & $\begin{array}{l}\text { Agricultural Health Study: } 17,357 \text { children of } \\
\text { lowa pesticide applicators. }\end{array}$ & $\begin{array}{c}95 \% \mathrm{Cl} \text { of standardized incidence ratios: All cancers: } \\
1.03-1.79 ; \text { All lymphomas: } 1.13-4.19 ; \text {; Hodgkin's } \\
\text { lymphoma: } 1.06-6.14 ; 95 \% \text { Cl of odds ratio for fathers } \\
\text { not using resistant gloves: } 1.05-3.76\end{array}$ \\
\hline Ma et al. (2002) & $\begin{array}{l}\text { Exposure to household pesticides is associated with an } \\
\text { increased risk of childhood leukemia. }\end{array}$ & $\begin{array}{l}\text { Northern California Childhood Leukemia } \\
\text { study: } 162 \text { patients with leukemia (diagnosis } \\
\text { between } 1995 \text { and } 1999 \text { ) and } 162 \text { matched } \\
\text { controls. }\end{array}$ & $\begin{array}{c}\text { Significant effects on increased risk of childhood } \\
\text { leukemia and exposure to pesticides: exposure from } 1 \\
\text { year before birth to } 3 \text { years after (OR=2.8); during year } 2 \\
(\mathrm{OR}=3.6) ; 3 \text { months before pregnancy (OR=1.8); during } \\
\text { pregnancy (OR=2.1). }\end{array}$ \\
\hline Meinert et al. (2000) & $\begin{array}{l}\text { Some evidence for an increased leukemia risk for children } \\
\text { living on farms is found, as well as association between } \\
\text { household pesticides and risk of childhood leukemia or } \\
\text { lymphoma. }\end{array}$ & $\begin{array}{l}\text { Data collected: } 1,184 \text { children with leukemia, } \\
234 \text { with non-Hodgkin's lymphoma, and } 940 \\
\text { with a solid tumor, as well as } 2,588 \text { controls } \\
\text { in the states of West Germany (1993-97). }\end{array}$ & $\begin{array}{l}\text { Significant associations of: use of pesticides on farms } \\
\text { and childhood leukemia (OR=1.5); residential use of } \\
\text { insecticides and childhood lymphoma (OR=2.6). }\end{array}$ \\
\hline
\end{tabular}




\begin{tabular}{|c|c|c|c|}
\hline Reference & Main conclusions & Data & Quantitative Results \\
\hline Nielsen et al. (2010) & $\begin{array}{l}\text { Results suggest an interaction effect between exposure in } \\
\text { childhood to organophosphorus insecticides and a reduced } \\
\text { ability to detoxify that might lead to childhood brain tumors } \\
\text { (CBTs). }\end{array}$ & $\begin{array}{l}\text { Data collected: DNA samples obtained from } \\
\text { newborn screening archives for } 201 \text { cases } \\
\text { and } 285 \text { controls, born in California or } \\
\text { Washington State between } 1978 \text { and } 1990 .\end{array}$ & $\begin{array}{l}\text { Significant association between CBT and some genetic } \\
\text { polymorphisms among exposed children: PON1(108T) } \\
\text { allele (OR=1.8); FMO1(953-6A) allele (OR=2.7). This } \\
\text { associations are not significant for not exposed children. }\end{array}$ \\
\hline O'Leary et al. (2004) & $\begin{array}{l}\text { Exposure to pesticides in the environment is associated with } \\
\text { breast cancer risk under specific situations. }\end{array}$ & $\begin{array}{l}\text { Data collected: } 105 \text { breast cancer cases } \\
\text { (1980-1992) and } 210 \text { matched controls. } \\
\text { Pesticide exposure is estimated through } \\
\text { water measures and distance to hazardous } \\
\text { waste sites (HWS) using GIS. }\end{array}$ & $\begin{array}{c}\text { Significant effect on increased breast cancer risk for: } \\
\text { living within } 1 \text { mile of HWS containing organochlorine } \\
\text { pesticides (OR=2.8); women living on previously } \\
\text { agricultural land with age over } 26 \text { years at first birth } \\
\text { (compared with no agricultural land and age under } 26 \\
\text { years at first age) } O R=6.4 \text {. }\end{array}$ \\
\hline Pearce et al. (2006) & $\begin{array}{l}\text { Results do not support a role for preconception paternal } \\
\text { occupational exposures to pesticides or herbicides in the } \\
\text { etiology of childhood cancer. }\end{array}$ & $\begin{array}{l}\text { Data collected: } 4,032 \text { cases from the } \\
\text { Northern Region Young Persons' Malignant } \\
\text { Disease Registry (RYPMDR), and 183,083 } \\
\text { controls from the same source and from the } \\
\text { Cumbrian Births Database. }\end{array}$ & $\begin{array}{l}\text { Significant associations only for male subjects using the } \\
\text { RYPMDR controls for pesticide exposure and: } \\
\text { Neuroblastoma and ganglione uroblastoma (OR=2.38); } \\
\text { Fibrosarcoma and other fibromatous neoplasm } \\
\text { (OR=3.89). }\end{array}$ \\
\hline Rudant et al. (2007) & $\begin{array}{l}\text { The findings go in line with the hypothesis of domestic use of } \\
\text { pesticides playing a role in the etiology of childhood } \\
\text { hematopoietic malignancies. }\end{array}$ & $\begin{array}{l}\text { ESCALE (Etude sur les cancers de l'enfant): } \\
1,060 \text { incident cases of hematopoietic } \\
\text { malignancies included (cases in France, from } \\
2003 \text { to 2004). }\end{array}$ & $\begin{array}{l}\text { Significant effects of insecticide use during pregnancy } \\
\text { on: childhood acute leukemia (OR=2.1); non-Hodgkin } \\
\text { lymphoma (1.8); Burkitt lymphoma (OR=2.7). }\end{array}$ \\
\hline Safi (2002) & $\begin{array}{l}\text { Heavy use and misuse of pesticides and other toxic } \\
\text { substances in the Gaza environment is suspected to } \\
\text { correlate with the growing incidence of Cancer. }\end{array}$ & $\begin{array}{l}\text { Data collected: Pesticide usage in Gaza } \\
\text { Governorates was recorded from 1990-1999. } \\
2,277 \text { cases of cancer in males and 2,458 in } \\
\text { females were analyzed. }\end{array}$ & $\begin{array}{l}\text { Significant associations of cancer incidence and type of } \\
\text { pesticide: insecticides } 0.992(p<0.001) \text {; fungicides } 0.952 \\
(p<0.001) \text {; herbicides } 0.812(p=0.004) \text {; nematicides } \\
0.925(p<0.001) \text {. }\end{array}$ \\
\hline Shim et al. (2009) & $\begin{array}{l}\text { Significant associations between parental exposure to } \\
\text { pesticides and risk of astrocytoma in offspring is found, } \\
\text { except for primitive neuroectodermal tumors. }\end{array}$ & $\begin{array}{l}\text { Data collected: } 526 \text { cases and the same } \\
\text { number of matched controls, located in one } \\
\text { of four U.S. Atlantic Coast states. }\end{array}$ & $\begin{array}{l}\text { Significant effects of parental herbicide exposure from } \\
\text { residential use and risk of astrocytoma (OR=1.9), and in } \\
\text { the case of both, residential and occupational exposure } \\
\text { (OR=1.8). }\end{array}$ \\
\hline Ward et al. (2009) & $\begin{array}{l}\text { Polychlorinated biphenyl congeners (PCBs) may represent a } \\
\text { risk factor for childhood acute lymphocytic leukemia (ALL). }\end{array}$ & $\begin{array}{l}\text { Data collected: } 184 \text { cases of ALL (kids } 0-7 \\
\text { years old) and } 212 \text { matched controls. } 35 \\
\text { counties in northern and central California } \\
(2000-06) \text {. Carpet dust samples collected. }\end{array}$ & $\begin{array}{c}\text { Significant associations of PCBs residues in the carpet } \\
\text { dust and higher risk of ALL (OR=1.97). Comparing } \\
\text { highest quartile with the lowest (in terms of PCBs } \\
\text { residues) OR=2.78. }\end{array}$ \\
\hline \multicolumn{4}{|c|}{ DEPRESSION \& NEUROLOGICAL DEFICITS } \\
\hline Beseler et al. (2006) & $\begin{array}{l}\text { Pesticide poisoning may contribute to risk of depression of } \\
\text { spouses of pesticide applicators. }\end{array}$ & $\begin{array}{l}\text { Agricultural Health Study: } 29,074 \text { spouses of } \\
\text { private pesticide applicators of lowa and } \\
\text { North Carolina. }\end{array}$ & $\begin{array}{l}\quad 95 \% \mathrm{Cl} \text { of Odds ratios: } \\
\quad \text { History of pesticide poisoning: } 1.72-6.19 \\
\text { Low cumulative pesticide exposure: } 0.91-1.31 \\
\text { High cumulative pesticide exposure: } 0.91-1.31\end{array}$ \\
\hline Bouchard et al. (2011) & $\begin{array}{l}\text { Prenatal dialkyl phosphate (DAP) concentrations are } \\
\text { associated with poorer intellectual development in } 7 \text {-year-old } \\
\text { children. }\end{array}$ & $\begin{array}{l}\text { CHAMACOS study: Birth cohort study among } \\
\text { Latino farmworker families from California. } \\
\text { Final sample of } 329 \text { children. }\end{array}$ & $\begin{array}{c}\text { Effect: } 10 \text {-fold increase in maternal DAP, DM, and DE } \\
\text { concentrations over IQ. Coefficient (95\% CI): } \\
\text { DAP: -5.6 (-9.0 to }-2.2) \text {; DM: }-4.7(-7.7 \text { to }-1.6) ; \\
\text { DE: }-2.8 \text { (-5.6 to } 0.3)\end{array}$ \\
\hline
\end{tabular}




\begin{tabular}{|c|c|c|c|}
\hline Reference & Main conclusions & Data & Quantitative Results \\
\hline Brender et al. (2010) & $\begin{array}{l}\text { Neural tube defects (NTD) are associated with preconception } \\
\text { residence within } 0.25 \text { miles of cultivated fields, and use of } \\
\text { pesticides within the home. }\end{array}$ & $\begin{array}{l}\text { Data collected: } 184 \text { Mexican American case } \\
\text { women and } 225 \text { controls interviewed } \\
\text { regarding environmental and occupational } \\
\text { exposure to pesticides. }\end{array}$ & $\begin{array}{l}\text { Significant associations of NTD affected pregnancies } \\
\text { with: living within } 0.25 \text { miles of cultivated fields ( } \mathrm{OR}=3.6) \text {; } \\
\text { exposure to pesticides twice }(\mathrm{aOR}=2.3) \text { or three times } \\
(\mathrm{aOR}=2.8) \text {. }\end{array}$ \\
\hline Eskenazi et al. (2007) & $\begin{array}{l}\text { Significant adverse associations of prenatal exposure to } \\
\text { pesticides with mental development and pervasive } \\
\text { developmental problems at } 24 \text { months old are reported. }\end{array}$ & $\begin{array}{l}\text { Data collected: children's performance } \\
\text { measures at } 6 \text { ( } n=396), 12 \text { ( } n=395) \text {, and } 24 \\
(\mathrm{n}=372), \text { and urine samples (mother and } \\
\text { child) in Latino families in California. }\end{array}$ & $\begin{array}{c}\text { Significant associations between prenatal } \\
\text { dialkliphosphate exposure with risk of pervasive } \\
\text { developmental disorder }(\mathrm{OR}=2.3) \text {, and for postnatal } \\
\text { exposure }(\mathrm{OR}=1.7) \text {. }\end{array}$ \\
\hline Eskenazi et al. (2010) & $\begin{array}{l}\text { PON1 is correlated with child neurobehavioral development, } \\
\text { bur more research is needed to confirm if it modifies the } \\
\text { relation with in utero OP exposure. }\end{array}$ & $\begin{array}{l}\text { CHAMACOS study: Longitudinal birth cohort } \\
\text { study among primarily Latino farmworker } \\
\text { families at California. Final sample of } 371 \\
\text { mothers (with respective children). }\end{array}$ & $\begin{array}{l}\text { Effect of 10x increase in maternal DM DAP levels on } \\
\text { child MDI scores, dependent on genes: } \\
\text { PON1[-108CC]: }-2.2(p=0.45) \\
\text { PON1[-108CT]: }-3.4(p=0.09) \\
\text { PON1[-108TT]: }-5.9(p=0.03)\end{array}$ \\
\hline Guodong et al. (2012) & $\begin{array}{l}\text { No significant associations are found between child urinary } \\
\text { levels of organophosphate pesticides (OPs) metabolites and } \\
\text { any of the developmental quotients (DQ) scores. }\end{array}$ & $\begin{array}{l}\text { Data collected: } 301 \text { children between } 23 \text { and } \\
25 \text { months old, recruited from } 2 \text { community } \\
\text { hospitals in Shanghai from February to } \\
\text { October } 2008 .\end{array}$ & $\begin{array}{l}\text { Children have relatively higher levels of OP urinary } \\
\text { metabolites compared with developed countries reports, } \\
\text { but no significant association is found between these and } \\
\text { the DQ scores. }\end{array}$ \\
\hline Harari et al. (2010) & $\begin{array}{l}\text { Prenatal exposure to pesticides can cause lasting adverse } \\
\text { effects on brain development in children, even for levels not } \\
\text { producing adverse health outcomes in the mother. }\end{array}$ & $\begin{array}{l}\text { Data collected: } 84 \text { children attending a local } \\
\text { public school in northern Ecuador, with } 35 \\
\text { exposed to pesticides via maternal } \\
\text { occupational exposure, and } 23 \text { with indirect } \\
\text { exposure from paternal work. }\end{array}$ & $\begin{array}{l}\text { Prenatal exposures to pesticides as predictor of adverse } \\
\text { effects [95\% Cl] at } 6-8 \text { years old: } \\
\text { Visual-performance functions: }-0.7 \text { [ }-1.3 \text { to }-.01] \\
\text { Blood pressure (Systolic): } 3.3 \text { [0.5 to } 6.1]\end{array}$ \\
\hline Parrón et al. (2011) & $\begin{array}{l}\text { Environmental exposure to pesticides may affect the human } \\
\text { health by increasing the incidence of neurological disorders } \\
\text { for the entire population living in the area exposed. }\end{array}$ & $\begin{array}{l}\text { Data collected: } 17,429 \text { cases of neurological } \\
\text { disorders collected from hospital records in } \\
\text { the south of Spain (1998-2005). }\end{array}$ & $\begin{array}{c}\text { Population living in areas with high pesticide use has an } \\
\text { increased risk for: Alzheimer's disease (aOR=1.65); } \\
\text { suicide attempts (aOR=1.76); polyneuropathies (males } \\
\text { aOR=1.68). }\end{array}$ \\
\hline Rastogi et al. (2010) & $\begin{array}{l}\text { Some neurologic self-reported symptoms, such as headache, } \\
\text { watering in eyes, and burning sensation in eyes or face, are } \\
\text { the clinical manifestations most attributed to } \\
\text { organophosphate pesticide exposure (OP). }\end{array}$ & $\begin{array}{l}\text { Data collected: neurologic signs and } \\
\text { symptoms from } 225 \text { rural children that belong } \\
\text { to agricultural families, and } 50 \text { children as } \\
\text { suitable reference group, in India. }\end{array}$ & $\begin{array}{l}\text { Symptoms associated to OP exposure: maximum } \\
\text { prevalence of salivation ( } 18.22 \% \text { of the cases), } \\
\text { lacrimation }(17.33 \% \text { ), diarrhea (9.33\%), excessive } \\
\text { sweating }(13.78 \%) \text {, tremors }(9.3 \%) \text {, mydriasis }(8.4 \%) \text {. }\end{array}$ \\
\hline Rauh et al. (2011) & $\begin{array}{l}\text { There exists significant effect of prenatal CPF exposure on } \\
\text { deficits in Working Memory Index and Full-Scale IQ at } 7 \\
\text { years of age. }\end{array}$ & $\begin{array}{l}\text { Data collected: } 265 \text { children participants in a } \\
\text { prospective study of air pollution, at } \\
\text { Columbia Center for Children's } \\
\text { Environmental Health. }\end{array}$ & $\begin{array}{c}\text { For each sd increase in CPF exposure }(4.61 \mathrm{pg} / \mathrm{g}) \text { there } \\
\text { is an IQ decline of } 1.4 \% \text {, and also on Working Memory } \\
\text { by } 2.8 \% \text {. }\end{array}$ \\
\hline Yesavage et al. (2004) & $\begin{array}{l}\text { No increasing prevalence of Parkinsonism attributable to } \\
\text { wind drift of pesticides could be found. }\end{array}$ & $\begin{array}{l}\text { Data collected: VA clinical pharmacy } \\
\text { datasets for prescription of antiparkinsonian } \\
\text { drugs in the coastal San Francisco Bay } \\
\text { (1997-2001), and total number of patients } \\
\text { receiving prescription of any other kind. }\end{array}$ & $\begin{array}{l}\text { There is a significant correlation between Parkinsonism } \\
\text { and pesticide use (r=0.53), but the prevalence of the } \\
\text { disease is not higher in the zones downwind of the } \\
\text { prevailing winds. }\end{array}$ \\
\hline \multicolumn{4}{|c|}{ DIABETES } \\
\hline Everett et al. (2010) & $\begin{array}{l}\text { Evidence supporting an increased risk of diabetes among } \\
\text { gross population is strongest for heptachlor epoxide and p,p'- } \\
\text { DDT, intermediate for oxychlordane, and least for beta- } \\
\text { hexachlorocyclohexane, p,p'-DDE, and trans-nonachlor. }\end{array}$ & $\begin{array}{l}\text { National Health and Nutrition Examination } \\
\text { Survey, 1999-2004. }\end{array}$ & $\begin{array}{c}95 \% \mathrm{Cl} \text { of odds ratios: } \\
\text { beta-hexachlorocyclohexane }(0.76,1.63) \text {; p,p'-DDE } \\
(0.98,2.55) ; \mathrm{p}, \mathrm{p}^{\prime}-\mathrm{DDT}(1.03,2.32) ; \text { oxychlordane } \\
(0.88,1.88) \text {; trans-nonachlor }(0.88,1.90) \text {; heptachlor } \\
\text { epoxide }(1.04,2.01)\end{array}$ \\
\hline & & & Continue on the next page \\
\hline
\end{tabular}




\begin{tabular}{|c|c|c|c|}
\hline Reference & Main conclusions & Data & Quantitative Results \\
\hline Son et al. (2010) & $\begin{array}{l}\text { Low-dose background exposure to OC pesticides is strongly } \\
\text { associated with prevalent type } 2 \text { diabetes in Koreans. Asians } \\
\text { may be more susceptible to adverse effects of OC pesticides } \\
\text { than other races. }\end{array}$ & $\begin{array}{l}\text { Data collected: From participants in a } \\
\text { community-based health survey in Korea: } 40 \\
\text { randomly selected diabetic patients; and } 40 \\
\text { controls. }\end{array}$ & $\begin{array}{c}\text { Odds ratios in the 3rd tertile of OC pesticide }(95 \% \mathrm{Cl}) \\
\text { range: } \\
\text { Heptachlorepoxide: } 3.1(0.8-12.1) \\
\text { Oxychlordane: } 26.0(1.3-517.4)\end{array}$ \\
\hline \multicolumn{4}{|c|}{ RESPIRATORY } \\
\hline Balluz et al. (2000) & $\begin{array}{l}\text { The health complaints reported by the employees at a health } \\
\text { center in Georgia with possible pesticide exposure were } \\
\text { precipitated by both environmental and psychological factors. } \\
\text { The perception of odors, inadequate air flow, and length of } \\
\text { employment are significantly associated with the employees' } \\
\text { health complaints. }\end{array}$ & $\begin{array}{l}\text { Data collected in a health center in Georgia: } \\
\text { Environmental monitoring for standard } \\
\text { indoor-air environmental quality parameters, } \\
117 \text { questionnaires answered by workers of } \\
\text { this center, } 85 \text { serum samples, and } 90 \text { urine } \\
\text { samples. }\end{array}$ & $\begin{array}{c}\text { Significant odds ratios of psychological predictors for: } \\
\text { Sinusitis: Knowing someone with similar symptoms: } 9.1 \text {; } \\
\text { Work hard very often: } 9.8 \text {. } \\
\text { Eye irritation: Knowing someone with similar symptoms: } \\
9.2 \\
\text { Headache: Knowing someone with similar symptoms: } \\
6.4 ; \text { Work hard very often: } 4.1\end{array}$ \\
\hline \multicolumn{4}{|c|}{ WOMEN SPECIFIC DISORDERS } \\
\hline Arbuckle et al. (2001) & $\begin{array}{l}\text { Evidence suggesting an association between pesticide } \\
\text { exposure and spontaneous abortions is found. Timing of } \\
\text { exposure is important characterizing the increase in risk. }\end{array}$ & $\begin{array}{l}\text { Ontario Farm Family Health Study: } 2,110 \\
\text { women providing information on } 3,936 \\
\text { pregnancies, including } 395 \text { spontaneous } \\
\text { abortions. }\end{array}$ & $\begin{array}{c}\text { Significant associations of early abortions with } \\
\text { preconception exposure to: phenoxy acetic acid } \\
\text { herbicides (OR=1.5); triazines }(\mathrm{OR}=1.4) \text {; any herbicide } \\
\text { (OR=1.4). For late abortions, preconception exposure to: } \\
\text { glyphosate (OR=1.7); thiocarbamates }(\mathrm{OR}=1.8) \text {; other } \\
\text { pesticides }(\mathrm{OR}=1.5) \text {. }\end{array}$ \\
\hline Garry et al. (2002) & $\begin{array}{l}\text { The results suggest that miscarriage risk increase during } \\
\text { spring is associated with specific herbicides applied by their } \\
\text { partners, and throughout the year in spouses of applicators } \\
\text { using fungicides. }\end{array}$ & $\begin{array}{l}\text { Data collected: } 802 \text { spouses of male } \\
\text { pesticide applicators located in the } 5 \text {-county } \\
\text { Red River Valley area, Minnesota. }\end{array}$ & $\begin{array}{l}\text { Increased miscarriage risk in the spring is significantly } \\
\text { associated with use (by the male partner) of: sulfonylurea } \\
(\mathrm{OR}=2.1) \text {; imidizolinone }(\mathrm{OR}=2.6) \text {; herbicide Cheyenne } \\
(\mathrm{OR}=2.9) \text {. And during the whole year with the use of } \\
\text { fungicides: organotin (OR=1.55); EBDC (OR=1.77). }\end{array}$ \\
\hline \multicolumn{4}{|c|}{ GENERAL HEALTH, MULTIPLE DISEASES AND OTHERS } \\
\hline Acosta et al. (2009) & $\begin{array}{l}\text { The results suggest a relationship between prenatal } \\
\text { exposure to pesticides and placental maturity, and may affect } \\
\text { the nutrient transport from mothers to the fetus. }\end{array}$ & $\begin{array}{l}\text { Data collected: analysis of the placentas of } \\
\text { exposed women }(n=9), \text { and non-exposed } \\
\text { women }(n=31 \text { preterm). }\end{array}$ & $\begin{array}{l}\text { Pesticide exposure significantly associated with higher } \\
\text { placental maturity index (PMI) (betha=7.38). Birth weight } \\
\text { and gestational age significantly correlated with PMI } \\
\text { (r=0.54 and } \mathrm{r}=0.44 \text {, respectively). }\end{array}$ \\
\hline Ahamed et al. (2006) & $\begin{array}{l}\text { Results do not support any association between exposure to } \\
\text { organochlorines and risk of childhood aplastic anaemia. }\end{array}$ & $\begin{array}{l}\text { Data collected: } 17 \text { cases of childhood } \\
\text { aplastic anaemia and } 17 \text { controls, between } 3 \\
\text { and } 12 \text { years old, enrolled in Lucknow, India } \\
\text { (2003-2004). }\end{array}$ & $\begin{array}{l}\text { The only significant difference is found on alpha- } \\
\text { hexachlorocyclohexane concentrations between cases } \\
\text { (6.84) and controls (5.49). }\end{array}$ \\
\hline Aminov et al. (2013) & $\begin{array}{c}\text { Polychlorinated biphenyls (PCBs) and organochlorine } \\
\text { pesticides are associated with elevations in serum lipids, } \\
\text { cholesterol and triglycerides. }\end{array}$ & $\begin{array}{l}\text { Data collected: serum samples obtained from } \\
575 \text { residents of Aniston, and were analyzed } \\
\text { for pesticide residues. }\end{array}$ & $\begin{array}{l}\text { Significant associations (Model } 1 \text { ) between pesticides } \\
\text { exposure and: total lipids (betha }=0.07 \text { ); total cholesterol } \\
\text { (betha }=0.04 \text { ); triglycerides (betha }=0.15) \text {. }\end{array}$ \\
\hline Andersen et al. (2012) & $\begin{array}{l}\text { The results indicate an interaction between prenatal pesticide } \\
\text { exposure and the PON1 gene, such that children with the R- } \\
\text { allele develop adverse cardiovascular risk profiles. }\end{array}$ & $\begin{array}{l}\text { Data collected: PON1-genotype determined } \\
\text { for } 88 \text { pesticide exposed (prenatal) cases, } \\
\text { and } 53 \text { controls, in Denmark (1996-2000). }\end{array}$ & $\begin{array}{l}\text { Significant higher means of high exposed (prenatal) } \\
\text { group (compared to unexposed) for: abdominal } \\
\text { circumference (65.9cm); sum of four skin folds }(52 \mathrm{~mm}) \text {; } \\
\text { body fat percentages }(22.3 \%) \text {. }\end{array}$ \\
\hline Berkowitz et al. (2004) & $\begin{array}{l}\text { Data analysis suggest that chlorpyrifos may have a } \\
\text { detrimental effect on fetal neurodevelopment among mothers } \\
\text { who exhibit low PON1 activity, due to small head sizes of the } \\
\text { offspring. }\end{array}$ & $\begin{array}{l}\text { Data collected: } 404 \text { births between May } 1998 \\
\text { and May } 2002 \text { at Mount Sinai Hospital in } \\
\text { New York City. }\end{array}$ & $\begin{array}{l}\text { Significant effect on head circumference of the offspring } \\
\text { for mothers with low PON1 activity with TCPy (pesticide } \\
\text { exposure) above the level of detection: } \text { mean = 33.3 } \\
\qquad(p=0.014) .\end{array}$ \\
\hline & & & Continue on the next page \\
\hline
\end{tabular}




\begin{tabular}{|c|c|c|c|}
\hline Reference & Main conclusions & Data & Quantitative Results \\
\hline Boucher et al. (2013) & $\begin{array}{l}\text { Prenatal exposure to chlordecone is associated with specific } \\
\text { impairments in fine motor function in boys. }\end{array}$ & $\begin{array}{l}\text { Data collected: study conducted in } \\
\text { Guadaloupe, measuring exposure to } \\
\text { chlordecone at birth }(n=141), \text { and at } 3 \\
\text { months postpartum }(n=75) \text {. Development } \\
\text { assess by the Ages and Stages } \\
\text { Questionnaire. }\end{array}$ & $\begin{array}{l}\text { Significant differences on fine motor scores according to } \\
\text { the chlordecone concentration levels at birth: undetected } \\
101.5 \text {, low } 103.0 \text {, high } 94.8 \text {. ( } p=0.029 \text { obtained from } \\
\text { analyses of variance ANOVAs). }\end{array}$ \\
\hline Burns et al. (2012) & $\begin{array}{l}\text { Serum OCP concentrations on 8-9 year-old kids are } \\
\text { associated with reduced BMI during peripubertal period. }\end{array}$ & $\begin{array}{l}\text { Data collected: Cohort of } 350 \text { boys enrolled } \\
\text { in the Russian Children's Study between } \\
2003 \text { and } 2005 \text { at } 8-9 \text { years of age, with } \\
\text { serum OCPs measure at study entry. }\end{array}$ & $\begin{array}{c}\text { Effect of OCPs concentration [95\% Cl] on BMI z-scores: } \\
\text { HCB: }-0.84(-1.23,-0.46) \\
\text { beta-HCH: }-1.32(-1.70,-0.95) \\
\text { p,p'-DDE: }-1.37(-1.75,-0.98) .\end{array}$ \\
\hline Cecchi et al. (2012) & $\begin{array}{l}\text { The increase in cortisol (CT) levels in the maternal } \\
\text { compartment may lead to impaired newborn health later in } \\
\text { life. Results suggest an endocrine disruption during } \\
\text { pregnancy due to environmental OPs exposure. }\end{array}$ & $\begin{array}{l}\text { Data collected: } 97 \text { healthy pregnant women, } \\
\text { between } 15 \text { and } 36 \text {, entering prenatal care at } \\
\text { the Allen Public Hospital, in Argentina, from } \\
\text { Nov } 2007 \text { to Aug } 2008 \text {. }\end{array}$ & $\begin{array}{l}\text { Significant increase of CT levels during the first trimester } \\
\text { of pregnancy: } 55 \%(p-\text {-value }<0.01) .\end{array}$ \\
\hline Chevrier et al. (2008) & $\begin{array}{l}\text { The exposure to polychlorinated biphenyls (PCBs) or } \\
\text { hexachlorobenzene may affect thyroid function during } \\
\text { pregnancy. }\end{array}$ & $\begin{array}{l}\text { CHAMACOS study: serum samples from } 334 \\
\text { pregnant women living in the Salinas Valley } \\
\text { California (1999-2000). }\end{array}$ & $\begin{array}{l}\text { Significant adjusted associations between free thyroxine } \\
\text { and: PCBs (betha= }-0.12) \text {; hexachlorobenzene (betha= } \\
0.08) .\end{array}$ \\
\hline Dabrowsky et al. (2003) & $\begin{array}{l}\text { Maternal exposure to pesticides may contribute to a slight } \\
\text { reduction in the duration of pregnancy and to a slower pace } \\
\text { of fetal development (this last effect is of borderline } 95 \% \\
\text { significance). }\end{array}$ & $\begin{array}{l}\text { Data collected: } 117 \text { women delivering infants } \\
\text { with low birth weight and } 377 \text { with average } \\
\text { birth weights, in the region of Lodz, Poland } \\
\text { (1998-2001). }\end{array}$ & $\begin{array}{l}\text { Significant effect of pesticide exposure in } 1 \text { st or } 2 \mathrm{nd} \\
\text { trimester (compared to non-exposed) on: pregnancy } \\
\text { duration (betha=-0.53 weeks, } p=0.052 \text { ); birth weight at } \\
\text { given pregnancy duration (betha=-103g, } p=0.067 \text { ). }\end{array}$ \\
\hline Fenster et al. (2006) & $\begin{array}{l}\text { No adverse associations between maternal serum } \\
\text { organochlorine levels and birth weight or crown-heel length is } \\
\text { found. Some evidence regarding decreases length of } \\
\text { gestation with lipid-adjusted hexachlorobenzene is found. }\end{array}$ & $\begin{array}{l}\text { CHAMACOS study: birth cohort of } 385 \text { low- } \\
\text { income Latinas living in the Salinas Valley } \\
\text { community, California. }\end{array}$ & $\begin{array}{c}\text { Only lipid-adjusted hexachlorobenzene levels were found } \\
\text { significant (but small) for decreased length of gestation } \\
\text { (betha= }-0.47 \text { weeks). No other association is } \\
\text { significant. }\end{array}$ \\
\hline Fowler et al. (2007) & $\begin{array}{l}\text { Exposure to concentrations of environmental chemicals could } \\
\text { affect the fetal human Leydig cell, potentially leading to } \\
\text { subtle dysregulation of reproductive development and adult } \\
\text { fecundity. }\end{array}$ & $\begin{array}{l}\text { Data collected: Human fetal tests were } \\
\text { collected during the } 2 \text { nd trimester. Testis } \\
\text { explants were cultured for } 24 \text { hours in the } \\
\text { presence and absence of LH and dieldrin. }\end{array}$ & $\begin{array}{c}\text { Significant effects of exposure to dieldrin on: reduced LH } \\
\text { induced testosterone secretion }(p<0.05) \text {; steroid acute } \\
\text { regulatory protein }(p<0.05) \text {. }\end{array}$ \\
\hline Freire et al. (2011) & $\begin{array}{l}\text { Early exposure to certain environmental chemicals } \\
\text { associated with endocrine-disruption may interfere with } \\
\text { neonatal thyroid hormone status. }\end{array}$ & $\begin{array}{l}\text { Data collected: } 17 \text { organochlorine pesticides } \\
\text { analyzed in } 220 \text { placentas from a male birth } \\
\text { cohort in Southern Spain. }\end{array}$ & $\begin{array}{c}\text { Significant effect on the odds of thyroid-stimulating } \\
\text { hormone cord blood levels over } 5 \mathrm{mU} / \mathrm{L} \text { for exposure to: } \\
\text { endrin (higher odds, OR=2.05); endosulfansulfate (lower } \\
\text { odds, OR=0.36). }\end{array}$ \\
\hline Harley et al. (2011) & $\begin{array}{l}\text { Infants with specific PON1 genotypes and enzyme activity } \\
\text { levels (suggesting susceptibility to effects of pesticides) have } \\
\text { decreased fetal growth and length of gestation. }\end{array}$ & $\begin{array}{l}\text { CHAMACOS study: } 470 \text { pregnant women } \\
\text { from the community of Salinas Valley, } \\
\text { California, whose urine samples were } \\
\text { analyzed twice during pregnancy. }\end{array}$ & $\begin{array}{l}\text { PON1-180TT genotype with significant associations } \\
\text { (compared to genotype 108CC) between pesticide } \\
\text { exposure and: shorter gestational age (betha= }-0.5 \\
\text { weeks); smaller head circumference (betha }=-0.4 \mathrm{~cm} \text { ). }\end{array}$ \\
\hline Hjollund et al. (2004) & $\begin{array}{l}\text { There is no increased risk of spontaneous abortion in invitro } \\
\text { fertilized (IVF) treated women attributable to paternal } \\
\text { exposure to pesticides and growth retardants. }\end{array}$ & $\begin{array}{l}\text { Data collected: } 128 \text { cases of pesticide } \\
\text { exposed partners and } 2925 \text { controls in } \\
\text { Denmark. }\end{array}$ & $\begin{array}{l}\text { The proportion of spontaneous abortions by type of } \\
\text { exposure are: } 19.7 \% \text { (herbicides), } 19.7 \% \text { (fungicides), } \\
21.3 \% \text { (pesticides), } 22.2 \% \text { (growth retardants), } 28.4 \% \\
\text { (controls). No statistical difference is found. }\end{array}$ \\
\hline Jurewicz et al. (2005) & $\begin{array}{l}\text { Infants of mothers performing heavy work inside greenhouse } \\
\text { during pregnancy have lower mean birth weight than infants } \\
\text { of mothers working out of greenhouse. }\end{array}$ & $\begin{array}{l}\text { Data collected: } 1,122 \text { pregnancies between } \\
1977 \text { and } 2001 \text { (386 of greenhouse workers, } \\
276 \text { of non-greenhouse workers, and } 460 \text { of } \\
\text { women who became pregnant during } \\
\text { maternity leave). }\end{array}$ & $\begin{array}{l}\text { Mean birth weight of greenhouse workers' infants is } \\
\text { 177gr lower than that of those of mothers working out of } \\
\text { greenhouses }(p=0.05) \text {. }\end{array}$ \\
\hline & & & Continue on the next page \\
\hline
\end{tabular}




\begin{tabular}{|c|c|c|c|}
\hline Reference & Main conclusions & Data & Quantitative Results \\
\hline Lee et al. (2002) & $\begin{array}{l}\text { Noncancer risks are uniformly higher for children due to a } \\
\text { proportionately greater inhalation rate-to-body weight ratio. } \\
\text { Potential health effects include neurologic and respiratory } \\
\text { effects, as well as cancer. }\end{array}$ & $\begin{array}{l}\text { Estimation of health risks using ambient air } \\
\text { data provided by the California Air Resources } \\
\text { Board and the California Department of } \\
\text { Pesticide Regulation. }\end{array}$ & $\begin{array}{l}\text { Hazard quotients (HQ) estimated for non-cancer effects, } \\
15 \text { different pesticides, and different type of exposure. } \\
\text { For chronic exposure, significant } \mathrm{HQs} \text { for Methylbromide } \\
\text { (95th percentile } \mathrm{HQ}=2.0 \text { ), and } 1,3-\mathrm{Bich} \text { loropropene (95th } \\
\text { percentile } \mathrm{HQ}=2.0) \text {. }\end{array}$ \\
\hline $\begin{array}{l}\text { Levario-Carrillo et al. } \\
\qquad(2004)\end{array}$ & $\begin{array}{l}\text { Prenatal exposure to pesticides is associated to the presence } \\
\text { of intrauterine growth retardation (IUGR). }\end{array}$ & $\begin{array}{l}\text { Data collected: } 79 \text { newborns from singleton } \\
\text { pregnancies with IUGR and } 292 \text { controls, in } \\
\text { Chihuahua, Mexico. }\end{array}$ & $\begin{array}{l}\text { Significant effect of pesticide exposure on IUGR: } \\
\text { aOR=2.3 }(95 \% \mathrm{Cl}: 1.0,5.3)\end{array}$ \\
\hline Marks et al. (2007) & $\begin{array}{l}\text { In utero and postnatal dialkyl phosphate (DAP) exposure is } \\
\text { associated adversely with attention, and this is stronger at } 5 \\
\text { years old than at } 3.5 \text {, and among boys. }\end{array}$ & $\begin{array}{l}\text { CHAMACOS study: } 331 \text { children assessed at } \\
\text { ages } 3.5 \text { years and } 323 \text { at } 5 \text { years. Different } \\
\text { tests applied and questionnaires answered } \\
\text { by the mother. }\end{array}$ & $\begin{array}{l}\text { Prenatal DAP is associated significantly with maternal } \\
\text { report of attention problems at age } 5 \text { years (betha=0.7), } \\
\text { and associated with scores on the Conners' Kiddie } \\
\text { Continuous Performance Test ADHD Confidence Index > } \\
\text { 70th percentile (OR=5.1). }\end{array}$ \\
\hline Murphy et al. (2007) & $\begin{array}{l}\text { The results of this study indicate that long-term health risks to } \\
\text { golfers from inhalation of } 15 \text { pesticides appear to be minimal } \\
\text { in the Northeastern U.S. }\end{array}$ & $\begin{array}{l}\text { Data collected: assessment of inhalation } \\
\text { health risk for } 15 \text { pesticides typically applied } \\
\text { to golf courses in Boston, Philadelphia, and } \\
\text { Rochester. }\end{array}$ & $\begin{array}{c}\text { For all pesticides and locations, the hazard quotient (HQ) } \\
\text { and the incremental lifetime cancer risk (ICR) are well } \\
\text { below critical values (1.0 and } 10^{\wedge}-6 \text { respectively). The } \\
\text { largest values found are, for HQ }\left(5.8 \times 10^{\wedge}-3\right) \text {, and for ICR } \\
\left(3.7 \times 10^{\wedge}-8\right) .\end{array}$ \\
\hline Nagayama et al. (2007) & $\begin{array}{l}\text { Greater exposure to dioxins, polychlorinated biphenyls } \\
\text { (PCBs), and organochlorine pesticides influences the } \\
\text { immune system of Japanese infants. }\end{array}$ & $\begin{array}{l}\text { Data collected: peripheral blood samples } \\
\text { analyzed from } 101 \text { Japanese infants of } \\
\text { approximately } 10 \text { months of age. }\end{array}$ & $\begin{array}{c}\text { Significant effects of: } \mathrm{HCH} \text { on HLA-DR+ }(\mathrm{OR}=0.33) \text {; HCE } \\
\text { on CD8+ (OR=2.34); Dioxins on } \mathrm{CD} 4+/ \mathrm{CD} 8+(\mathrm{OR}=1.71) \text {; } \\
\text { Chlordane on } \mathrm{CD} 3+(\mathrm{OR}=1.70) \text {. }\end{array}$ \\
\hline Petit et al. (2010) & $\begin{array}{l}\text { Agricultural activities in the municipality of residence (such as } \\
\text { cultivation of pea, potato, and wheat crops) may have a } \\
\text { negative effect on cranial growth }\end{array}$ & $\begin{array}{l}\text { Data collected: } 3,421 \text { pregnant women } \\
\text { recruited from the region of Brittany ( } 2002- \\
06) \text {. Area devoted to agricultural activities } \\
\text { was obtained from the national agricultural } \\
\text { census (2000). }\end{array}$ & $\begin{array}{l}\text { Risk of infants with small head circumference is } \\
\text { significantly higher for mothers living in municipalities } \\
\text { where peas (OR=2.2) were grown. For potatoes } \\
(\mathrm{OR}=1.5,95 \% \mathrm{Cl}: 0.9-2.4) \text { a potential association is also } \\
\text { found. }\end{array}$ \\
\hline Quiros-Alcala et al. (2011) & $\begin{array}{l}\text { No consistent associations is found between maternal and } \\
\text { child organophosphate pesticide exposure on children } \\
\text { autonomic nervous system (ANS) up to age } 5 \text { years. }\end{array}$ & $\begin{array}{l}\text { Data collected: number of measures of the } \\
\text { ANS varies between } 96 \text { and } 273 \text {, depending } \\
\text { on the age of subject and type of measure. } \\
\text { These measures were collected using the } \\
\text { CHAMACOS study. }\end{array}$ & $\begin{array}{l}\text { Only significant effect of pesticide exposure on resting } \\
\text { ANS measures is found for } 6 \text { month old children for } \\
\text { dimethyls (betha=-0.24) and diethyls (betha=-0.27), but } \\
\text { not at older ages. }\end{array}$ \\
\hline Rauch et al. (2012) & $\begin{array}{l}\text { Prenatal urinary dialkyl phosphate (DAP) concentrations are } \\
\text { associated with shortened gestation and reduced birth } \\
\text { weight, with some heterogeneity depending on race and } \\
\text { PON1 genotypes. }\end{array}$ & $\begin{array}{l}\text { HOME study: } 306 \text { pregnant women attending } \\
\text { seven prenatal clinics in the Cincinnati } \\
\text { metropolitan area (2003-2006), providing } \\
\text { urine samples at weeks } 16 \text { and } 26 .\end{array}$ & $\begin{array}{l}\text { 10-fold increase in DAP concentrations are associated } \\
\text { with a decrease in gestational age (betha= }-0.5 \text { weeks; } \\
95 \% \text { Cl: }-0.8,-0.1) \text { and birth weight (betha= }=-151 \text { gr; } 95 \% \\
\text { Cl: -287,-16). Results are different between white and } \\
\text { black newborns, and different PON1 genotypes. }\end{array}$ \\
\hline Ronda et al. (2005) & $\begin{array}{l}\text { Risk of fetal death in the offspring of agricultural workers } \\
\text { exposed to pesticides around the time of conception is higher } \\
\text { than in the offspring of nonagricultural workers in mothers } \\
\text { who were housewives (do not work outside). }\end{array}$ & $\begin{array}{l}\text { Data collected: } 587,360 \text { stillbirths and live } \\
\text { births obtained from the Stillbirth and Birth } \\
\text { National Register of Spain (1995-99). }\end{array}$ & $\begin{array}{l}\text { Significant adjusted relative risk of fetal death in } \\
\text { agricultural workers is } 1.68 \text { (95\% Cl: } 1.03,2.73) \text { for } \\
\text { mothers not working outside (housewives), compared } \\
\text { with their nonagricultural counterpart. }\end{array}$ \\
\hline & & & Continue on the next page \\
\hline
\end{tabular}




\begin{tabular}{|c|c|c|c|}
\hline Reference & Main conclusions & Data & Quantitative Results \\
\hline $\begin{array}{l}\text { Sathyanarayana et al. } \\
\text { (2010) }\end{array}$ & $\begin{array}{l}\text { Overall, no associations between birth weight and pesticide- } \\
\text { related activities during early pregnancy are observed, } \\
\text { except for one pesticide. However the lack of data on } \\
\text { temporal specificity of individual pesticide exposures limits } \\
\text { the results of this study. }\end{array}$ & $\begin{array}{l}\text { Agricultural Health Study: 2,246 farm women } \\
\text { in lowa and North Carolina. }\end{array}$ & $\begin{array}{l}\text { Statistically significant pesticides on birth weight: } \\
\text { Carbaryl: }-82 \mathrm{gr}(95 \% \mathrm{Cl}:-132,-31)\end{array}$ \\
\hline Wang et al. (2012) & $\begin{array}{l}\text { High pesticide levels might adversely affect duration of } \\
\text { gestation although this association is not present among } \\
\text { boys. Maternal urine pesticide levels in Shanghai are much } \\
\text { higher than those reported in developed countries. }\end{array}$ & $\begin{array}{l}\text { Data collected: } 187 \text { healthy pregnant women } \\
\text { between September } 2006 \text { and January } 2007, \\
\text { in Shanghai, China. }\end{array}$ & $\begin{array}{l}\text { Effect of log unit increase in diethylphosphate, on the } \\
\text { gestational duration in girls: } \\
-1.79 \text { weeks }(95 \% \text { Cl: }-2.82 \text { to }-0.76) \text {. }\end{array}$ \\
\hline Weselak et al. (2007) & $\begin{array}{l}\text { There is suggestive evidence that allergies and hay fever are } \\
\text { more common in offspring exposed to certain pesticides } \\
\text { during pregnancy, but this results should be confirmed. }\end{array}$ & $\begin{array}{l}\text { Ontario Farm Family Health Study: } 104 \\
\text { cough cases, } 173 \text { asthma cases, } 341 \text { allergy } \\
\text { cases, and } 2787 \text { controls. }\end{array}$ & $\begin{array}{c}\text { Significant effect of prenatal exposure and allergies for: } \\
\text { any pesticide (aOR=1.58), fungicides (aOR=1.69), } \\
\text { insecticides (aOR=1.48), herbicides (aOR=1.56), } \\
\text { phenoxy (aOR=1.43), organophosphates (aOR=1.55), } \\
\text { and 2,4-D (aOR=1.66). }\end{array}$ \\
\hline Weselak et al. (2008) & $\begin{array}{l}\text { The results suggest that pre-conception exposure to } \\
\text { cyanawine or dicamba is associated with an increase in risk } \\
\text { of birth defects in male offspring. }\end{array}$ & $\begin{array}{l}\text { Ontario Farm Family Health Study: } 3,412 \\
\text { pregnancies analyzed (108 pregnancies } \\
\text { ending in one or more birth defect). }\end{array}$ & $\begin{array}{l}\text { Significant effect of pre-conception exposure on } \\
\text { increased risk of birth defects in male offspring for: } \\
\text { cyanazine (OR=4.99); diacamba (OR=2.42). }\end{array}$ \\
\hline Wickerham et al. (2012) & $\begin{array}{l}\text { Evidence suggests that exposure to fungicides may } \\
\text { adversely impact fetal growth such as exposure to mixtures } \\
\text { of multiple pesticides, but more research is needed. }\end{array}$ & $\begin{array}{l}\text { Data collected: Subset of pregnant women } \\
\text { participating in a study. Women at } 36 \text { weeks } \\
\text { gestation and healthy were recruited from } \\
\text { Fuyang Maternal and Children's hospital. } \\
\text { Final sample of } 113 \text { pregnant women. }\end{array}$ & $\begin{array}{c}\text { Birth weight decreased by } 37.1 \mathrm{~g}(95 \% \mathrm{Cl}:-72.5,-1.8) \text { for } \\
\text { each detected pesticide. } \\
\text { In case of fungicides: }-116 \mathrm{~g}(95 \% \mathrm{Cl}:-212,-19.2) \\
\text { Vinclozoling: }-174 \mathrm{~g}(95 \% \mathrm{Cl}:-312,-36.3) \\
\text { Acetochlor: }-165 \mathrm{~g}(95 \% \mathrm{Cl}-325,-5.7) .\end{array}$ \\
\hline Young et al. (2005) & $\begin{array}{l}\text { Evidence suggests a detrimental association between } \\
\text { prenatal organophosphate pesticides (OP) exposure and } \\
\text { abnormal reflexes, particularly in infants assessed after } 3 \\
\text { days of life. }\end{array}$ & $\begin{array}{l}\text { CHAMACOS study: } 381 \text { infants under } 2 \\
\text { months of age from the Salinas Valley } \\
\text { community, California. }\end{array}$ & $\begin{array}{c}\text { Increasing prenatal urinary metabolite levels are } \\
\text { associated with the proportion of infants with more than } \\
\text { three abnormal reflexes for: dialkylphosphates (OR=4.9); } \\
\text { dimethyls ( } \mathrm{OR}=3.2 \text { ); diethyls (OR=3.4) (in kids over } 3 \\
\text { days old. }\end{array}$ \\
\hline Zhu et al. (2006) & $\begin{array}{c}\text { A little effect of occupational exposures to pesticides on } \\
\text { pregnancy outcomes among gardeners or farmers in } \\
\text { Denmark is found. }\end{array}$ & $\begin{array}{l}\text { Data collected: National Birth Cohort in } \\
\text { Denmark, collecting information on } 226 \\
\text { pregnancies of gardeners and } 214 \text { of farmers } \\
\text { (1997-2003). 62,164 other workers were } \\
\text { used as controls. }\end{array}$ & $\begin{array}{c}\text { The only significant increased risk found is a very } \\
\text { preterm birth for gardeners (aOR=2.6). But any other } \\
\text { association is insignificant. }\end{array}$ \\
\hline
\end{tabular}


Table 3. Consumers

\begin{tabular}{|c|c|c|c|}
\hline Reference & Main conclusions & Data & Quantitative Results \\
\hline \multicolumn{4}{|c|}{ CANCER } \\
\hline Buczynska et al. (2005) & $\begin{array}{l}\text { Results indicate: low cancer risk for people drinking water } \\
\text { contaminated with } p, \mathrm{p}^{\prime}-\mathrm{DDT} \text { and } \mathrm{p}, \mathrm{p}^{\prime}-\mathrm{DDD} \text {; low non-cancer } \\
\text { risk related to MCPA, MCPP and methoxychlor exposure. At } \\
\text { one dump site, exposure to 2,4'-D implies possible } \\
\text { hematopoietic, nephrotoxic and hepatotoxic effects, and } \\
\text { reproductive disorders. Possible health risk are calculated } \\
\text { from daily intake in drinking polluted water. }\end{array}$ & $\begin{array}{l}\text { Forty pesticide dump sites in Poland were } \\
\text { selected as the largest source of ecological } \\
\text { hazard. Two of them, close to residence are } \\
\text { and drinking water intakes were selected as } \\
\text { potentially most hazardous to health. Water } \\
\text { samples were collected and analyzed. }\end{array}$ & $\begin{array}{l}\text { Relative cancer risk for different pesticides: } \\
\text { p, } \mathrm{p}^{\prime}-\mathrm{DDT}: \mathrm{R}=1.83^{*} 10^{\wedge}(-8) \\
\mathrm{p}, \mathrm{p}^{\prime}-\mathrm{DDD}: \mathrm{R}=1.24^{*} 10^{\wedge}(-8) \\
\text { Hazard index for noncarcinogenic pesticides: } \\
\qquad 2,4^{\prime}-\mathrm{D}: \mathrm{HQ}=3\end{array}$ \\
\hline Li et al. (2008) & $\begin{array}{l}\text { Fish with pesticide residuals would not pose a health risk to } \\
\text { humans with a consumption of } 7.4 \text { to } 8.6 \mathrm{~g} / \text { person day, } \\
\text { however the hazardous ratio of the 95th percentile for PCBs } \\
\text { (Polychlorinated biphenyls) in fish from Gaobeidian Lake } \\
\text { exceeds } 1 \text { so daily exposure to PCBs has an increased } \\
\text { cancer risk. }\end{array}$ & $\begin{array}{l}\text { Concentration levels of pesticides in some } \\
\text { edible fish from Huairou Reservoir and } \\
\text { Gaobeidian Lake in Beijing, China. }\end{array}$ & $\begin{array}{l}\text { 95th percentile measured concentrations and Hazard } \\
\text { Rates (HR): } \\
\text { DDTs (Gaobeidian Lake): } 141.8, \mathrm{HR}=0.73 \\
\text { DDTs (Huairou Reservoir): } 117, \mathrm{HR}=0.61 \\
\text { PCBs (Gaobeidian Lake): } 33.0, \mathrm{HR}=1.01\end{array}$ \\
\hline Moon et al. (2009) & $\begin{array}{l}\text { Hazard ratios of non-cancer risk of all of the Ocs } \\
\text { (Organochlorines) are less than one, while the lifetime } \\
\text { cancer risks of PCBs and DDTs are all greater than unity. }\end{array}$ & $\begin{array}{l}\text { Measurement of organochlorines' levels (Ocs) } \\
\text { in } 26 \text { species of seafood commonly consumed } \\
\text { by the Korean population. }\end{array}$ & $\begin{array}{c}\text { Hazard ratios are presented only graphically, and the } \\
\text { values are not presented in the paper. Graphically is } \\
\text { clear that the hazard ratios for cancer risk is larger than } \\
1 \text { for PCBs among all ages. }\end{array}$ \\
\hline Pandit et al. (2002) & $\begin{array}{l}\text { Most organochlorine compounds in milk and milk products } \\
\text { are not present at high enough levels to cause cancer, with } \\
\text { the exception of a-HCH, whose cancer risk estimate } \\
\text { exceeds the US EPA guidance value. }\end{array}$ & $\begin{array}{l}\text { Data collected: Coming from } 520 \text { samples of } \\
\text { milk and milk products of different brands } \\
\text { available in the local market selected } \\
\text { randomly to determine concentration levels of } \\
\text { persistent organochlorine pesticides. }\end{array}$ & $\begin{array}{c}\text { Cancer potencies }(\mathrm{mg} \mathrm{kg}-1 \text { per } \mathrm{d})^{\wedge}-1 \text { for } \\
\text { organochlorines identified in milk and milk products: } \\
\alpha-\mathrm{HCH}: 6.3 ; \beta-\mathrm{HCH}: 1.8 ; \\
\text { Y-HCH: } 1.3 ; \text { DDE: } 0.34 \\
\text { DDT: } 0.34\end{array}$ \\
\hline \multicolumn{4}{|c|}{ GENERAL HEALTH, MULTIPLE DISEASES AND OTHERS } \\
\hline Bhanti et al. (2007) & $\begin{array}{l}\text { Pesticide residue concentrations in vegetables of different } \\
\text { season shows that the winter vegetables are the most } \\
\text { contaminated, followed by summer and rainy vegetables. } \\
\text { Even if concentration levels are well below the established } \\
\text { tolerances, continuous consumption of such vegetables can } \\
\text { accumulate in the receptor's body and may prove to be fatal } \\
\text { for human population in the long term. }\end{array}$ & $\begin{array}{l}\text { Data collected: Residuals concentration of } \\
\text { selected organophosphorous pesticides in } \\
\text { vegetables grown in different seasons. }\end{array}$ & $\begin{array}{l}\text { Hazard indexes as per maximum daily intakes of } \\
\text { pesticides residue through vegetables (>1 means } \\
\text { hazard risk): Methyl parathion: Summer (1.864); Rainy } \\
\text { (1.984); Winter (2.868); Chlorpyriphos: Summer } \\
\text { (0.313); Rainy (0.256); Winter ( }(0.294) ; \text { Malathion: } \\
\text { Summer (0.165); Rainy (0.128); Winter (0.176) }\end{array}$ \\
\hline
\end{tabular}


Table 4. WTP studies

\begin{tabular}{|c|c|c|c|c|c|}
\hline Reference & Country & Group & SPIRP & WTP reflects & WTP defined as \\
\hline Akgüngör et al. (2001) & Turkey & Consumers & SP: CVM & $\mathrm{H}$ & $\begin{array}{l}\text { Price premium per } \mathrm{kg} \text { tomatoes in which } \\
\text { pesticide residue do not cause health problems }\end{array}$ \\
\hline Al-Hassan et al. (2010) & Ghana & Farmers & SP: CVM & $M(P)$ & $\begin{array}{l}\text { Percentage increase in yield or reduced pest } \\
\text { control }\end{array}$ \\
\hline Atreya et al. (2012) & Nepal & Farmers & SP: CVM + RP: DE & $H-E$ & $\begin{array}{l}\text { Price premium in relation to household's } \\
\text { pesticide expenditures }\end{array}$ \\
\hline Balcombe et al. (2007) & UK & Consumers & SP: CVM & 0 & $\begin{array}{l}\text { Weekly price premium for a basket of food items } \\
\text { produced using a non-pesticide technology }\end{array}$ \\
\hline Balcombe et al. (2009) & UK & Consumers & SP: CE & E & $\begin{array}{l}\text { Price premium on bread from complete ban or } \\
\text { reduction in specified pesticides }\end{array}$ \\
\hline $\begin{array}{l}\text { Bernard and Bernard } \\
\qquad(2010)\end{array}$ & USA & Consumers & Experiment & $\mathrm{M}(\mathrm{GM})$ & $\begin{array}{l}\text { Price premium for organic potatoes and sweet } \\
\text { corn, where organic were divided into "no } \\
\text { pesticides" and "non-GM" }\end{array}$ \\
\hline Canavari et al. (2005) & Italy & Consumers & SP: CVM & $\mathrm{H}-\mathrm{E}-\mathrm{O}$ & $\begin{array}{l}\text { Yearly contribution for the abolition of the use of } \\
\text { pesticides and a price premium for organically } \\
\text { grown apples }\end{array}$ \\
\hline $\begin{array}{l}\text { Canavari and Nayga } \\
(2009)\end{array}$ & Italy & Consumers & SP: CVM & $M(G M)$ & $\begin{array}{l}\text { NA (Asked respondents if they were willing to } \\
\text { buy GM goods with either less pesticides (input) } \\
\text { or nutritionally enhanced (output)) }\end{array}$ \\
\hline Chalak et al. (2008) & UK & Consumers & SP: CE & $H-E$ & $\begin{array}{l}\text { Price premium for bread and weakly basket of } \\
\text { fruit and vegetables }\end{array}$ \\
\hline $\begin{array}{l}\text { Cranfield and Magnusson } \\
\qquad(2003)\end{array}$ & Canada & Consumers & SP: CVM & $H-E$ & Price premium of favorite food free of pesticide \\
\hline $\begin{array}{l}\text { Garming and Waibel } \\
\text { (2009) }\end{array}$ & Nicaragua & Farmers & SP: CVM & $\mathrm{H}$ & $\begin{array}{c}\text { Price premium per year in relation to "standard } \\
\text { pesticide" }\end{array}$ \\
\hline $\begin{array}{l}\text { Gifford and Bernard } \\
(2008)\end{array}$ & USA & Consumers & SP: CVM & O & $\begin{array}{l}\text { Price premium for a variety of food products } \\
\text { presented as "organic", "pesticide-free", and } \\
\text { "non-gm" }\end{array}$ \\
\hline Glenk et al. (2012) & UK & Consumers & SP: CE & $\mathrm{H}-\mathrm{E}$ & $\begin{array}{l}\text { Price premium on bottle of whisky from ban or } \\
\text { reduction in pesticide use }\end{array}$ \\
\hline & & & & & Continue on the next page \\
\hline
\end{tabular}




\begin{tabular}{|c|c|c|c|c|c|}
\hline Reference & Country & Group & SPIRP & WTP reflects & WTP defined as \\
\hline $\begin{array}{l}\text { Govindasamy et al. } \\
\qquad(2001)\end{array}$ & USA & Consumers & SP: CVM & M(IPM) & $\begin{array}{l}\text { NA (Respondents were asked if they were willing } \\
\text { to pay a } 10 \% \text { premium for IPM over the price of } \\
\text { conventional food). }\end{array}$ \\
\hline $\begin{array}{l}\text { Govindasamy et al. } \\
\qquad(2005)\end{array}$ & USA & Consumers & SP: CVM & $\mathrm{O}$ & $\begin{array}{l}\text { NA (Asked respondents if they were willing to } \\
\text { pay a percentage premium payment). }\end{array}$ \\
\hline $\begin{array}{l}\text { Haghiri and McNamara } \\
\qquad(2007)\end{array}$ & Canada & Consumers & SP: CVM & $H-E-(O)$ & $\begin{array}{l}\text { NA (Respondents were asked if they were willing } \\
\text { to pay a } 10 \% \text { premium for organically grown } \\
\text { fresh fruit and vegetables). }\end{array}$ \\
\hline Haghiri et al. (2009) & Canada & Consumers & SP: CVM & $H-E-(O)$ & $\begin{array}{l}\text { NA (Respondents were asked if they were willing } \\
\text { to pay a } 10 \% \text { premium for organically grown } \\
\text { fresh fruit and vegetables). }\end{array}$ \\
\hline Hamilton et al. (2003) & USA & Consumers & SP: CVM + Vote & $H-E$ & $\begin{array}{l}\text { NA (Price premium for pesticide-free food (and } \\
\text { vote on ban)). }\end{array}$ \\
\hline $\begin{array}{l}\text { Hammitt and Haninger } \\
\text { (2010) }\end{array}$ & USA & Consumers & SP: CVM & $\mathrm{H}$ & $\begin{array}{l}\text { WTP to reduce fatal-disease risk (caused by } \\
\text { consuming pesticide residues on foods). }\end{array}$ \\
\hline Huang et al. (2000) & USA & Consumers & SP: CVM & $\mathrm{M}(\mathrm{CRF})$ & $\begin{array}{l}\text { NA (Respondents ask if they had a positive } \\
\text { WTP for CRF (certified residue-free) produce; } \\
\text { if yes asked to choose their relative WTP } \\
\text { premium within percentage intervals). }\end{array}$ \\
\hline Khan (2009) & Pakistan & Farmers & SP: CVM & $\mathrm{H}$ & $\begin{array}{l}\text { NA (Price premium of pesticide that was just as } \\
\text { effective as their current one, but with no } \\
\text { adverse health effects). }\end{array}$ \\
\hline Loureiro et al. (2002) & USA & Consumers & SP: CVM & $\mathrm{O}$ & Price premium for eco-labeled apples \\
\hline Maguire et al. (2004) & USA & Consumers & RP: Hedonic & $\mathrm{O}$ & Price premium for organic baby food \\
\hline Marette et al. (2012) & France & Consumers & $\begin{array}{l}\text { Experiment + SP: } \\
\text { CVM }\end{array}$ & $\mathrm{O}$ & $\begin{array}{l}\text { Price (premium) per organic apple or apple with } \\
\text { a "few pesticides". }\end{array}$ \\
\hline Mourato et al. (2000) & UK & Consumers & SP: CR & $H-E$ & $\begin{array}{l}\text { Per case of human illness and one species of } \\
\text { farmland bird. }\end{array}$ \\
\hline Nielsen (2013) & Germany & Consumers & Experiment & $E-M(G M)$ & $\begin{array}{l}\text { NA (Subjects asked to choose between GM and } \\
\text { conventional fries at the same price.) }\end{array}$ \\
\hline Palis et al. (2006) & Philippines & Farmers & Experiment & $\mathrm{H}$ & $\begin{array}{l}\text { NA (Farmers' and laborers' were offered to buy } \\
\text { protective equipment). }\end{array}$ \\
\hline & & & & & Continue on the next page \\
\hline
\end{tabular}




\begin{tabular}{|c|c|c|c|c|c|}
\hline Reference & Country & Group & SPIRP & WTP reflects & WTP defined as \\
\hline Posri et al. (2007) & Thailand & Consumers & SP: CVM & $\mathrm{H}$ & $\begin{array}{l}\text { NA (Respondents were asked if they were } \\
\text { willing to pay a premium for "Chinese cabbage" } \\
\text { guaranteed to be in compliance with residue } \\
\text { limits determined by the government). }\end{array}$ \\
\hline Probst et al. (2012) & $\begin{array}{l}\text { Benin, Ghana, and } \\
\text { Burkina Faso }\end{array}$ & Consumers & SP: CE & 0 & $\begin{array}{l}\text { Price premium for plate of food served when } \\
\text { eating out }\end{array}$ \\
\hline Schou et al. (2006) & Denmark & Consumers & SP: CE & $\mathrm{E}$ & $\begin{array}{l}\text { Price premium of bread then converted to } \\
\text { household WTP per year for } 1 \% \text { increase in the } \\
\text { survival of partridge chicks and an increase of } 1 \\
\text { wild plant } / \mathrm{m} 2 \text {. }\end{array}$ \\
\hline $\begin{array}{l}\text { Sydorovych and Michele } \\
\qquad(2008)\end{array}$ & USA & Farmers & $\mathrm{RP}$ & $H-E$ & $\begin{array}{l}\text { Per acre per year for health risk reduction and } \\
\text { surface water risk reduction. }\end{array}$ \\
\hline $\begin{array}{l}\text { Travisi and Nijkamp } \\
(2008)\end{array}$ & Italy & Consumers & SP: CE & $H-E$ & $\begin{array}{l}\text { Annual household WTP per unit of bird species, } \\
\text { illness, contaminated farmland. }\end{array}$ \\
\hline \multicolumn{6}{|c|}{ a: SP and RP refer to stated- and revealed preferences with description of techniques used: contingent valuation (CVM), choice experiments (CE), defensive expenditures (DE) } \\
\hline$=$ Health, $\mathrm{E}=$ Environn & & $G M=$ gene & $\Lambda=$ integr & ement). 1 & cts is not explicitly stated in all s \\
\hline
\end{tabular}

